\title{
MODIFYING THE MINERAL PROFILE OF CRICKETS (Acheta domesticus) USING A
} SUPPLEMENTED DIET

\author{
A Thesis \\ presented to \\ the Faculty of California Polytechnic State University, \\ San Luis Obispo
}

In Partial Fulfillment

of the Requirements for the Degree

Master of Agriculture in Animal Science

by

Rhianne Morgan Le Maxwell

August 2018 
(C) 2018

Rhianne Morgan Le Maxwell

ALL RIGHTS RESERVED 


\section{COMMITTEE MEMBERSHIP}

TITLE: $\quad$ Modifying the Mineral Profile of Crickets (Acheta domesticus) Using a Supplemented Diet

AUTHOR: Rhianne Morgan Le Maxwell

DATE SUBMITTED: August 2018

COMMITTEE CHAIR: $\quad$ Mark S. Edwards, Ph.D.

Professor of Animal Science

COMMITTEE MEMBER: $\quad$ Darin C. Bennett, Ph.D.

Professor of Animal Science

COMMITTEE MEMBER: $\quad$ David H. Headrick, Ph.D.

Professor of Horticulture and Crops Science 


\begin{abstract}
Modifying the mineral profile of crickets (Acheta domesticus) using a supplemented diet Rhianne Morgan Le Maxwell
\end{abstract}

Captive insectivores may consume invertebrates as all, or part of their overall diet. The challenge with feeding captive insectivores involves the limited number of invertebrate species that are commercially available, and the lack of key nutrients provided by these insects. Among these insects, a naturally occurring low concentration of calcium and an inverse calcium to phosphorus ratio may put insectivores at the risk of developing hypocalcemia. A strategy to correct this nutrient imbalance involves supplementing the insect diet with high concentrations of targeted nutrients - a term referred to as gut-loading. Current industry guidelines recommend feeding a supplemented diet for 48 to $72 \mathrm{~h}$ before offering the insect to an insectivore. In the present study, the mineral profile of adult crickets (Acheta domesticus) offered a maintenance diet $(1.58 \% \mathrm{Ca}$, DMB) are compared to crickets offered a supplemented diet (11.32\% Ca, DMB) over $120 \mathrm{~h}$. The supplemented diet produced a cricket with significantly higher calcium concentration compared to the maintenance diet. The calcium concentration of crickets offered the supplemented diet was highest at $48 \mathrm{~h}(0.63 \%)$, but did not achieve a 1:1 Ca:P ratio nor meet the lowest reported nutrient requirements of carnivorous reptiles, omnivorous reptiles, or an insectivorous bird at various life stages. Although the supplemented diet improved the whole body calcium concentration in feeder crickets, the crickets do not provide adequate calcium, iron, or manganese to meet the requirement of insectivores. As evidenced by the current study, the supplemented crickets are not recommended to serve as the sole source of nutrition for an insectivore.

Keywords: Acheta domesticus, calcium, Ca:P, crickets, gut-loading, supplementation 


\section{ACKNOWLEDGMENTS}

This research project would not have been possible without the abundant support and efforts of every individual mentioned in this section.

My graduate adviser, Dr. Mark Edwards, has consistently proven to be an excellent mentor to me, stemming from my sophomore year of my undergraduate studies. Throughout my graduate studies, he has not only trained me in the field of comparative nutrition, but has also served as a role model for professionalism. Dr. Edwards has advocated for my research, provided me with invaluable insights, and contributed countless revisions to all works related to my research, to which I must express my utmost gratitude.

Dr. Darin Bennett has provided me many resources and a wealth of advice towards my project from my experimental design to the interpretation of my results. I thank him for his patience and willingness to take time out of his day to investigate a research topic with me.

Dr. David Headrick has both taught and mentored me as I ventured into the field of entomology, and encouraged me to learn through exploring multiple avenues of my research. I am grateful for both his advice towards my project and the foundation of entomological knowledge he has helped me build.

I sincerely thank the faculty and staff that dedicated their time and resources to this project:

Dr. Daniel Peterson, for graciously providing the space to conduct cricket feeding trials.

Dr. Chip Appel, for allowing us to utilize his laboratory space.

Craig Stubler for his input towards my project, and his dedication to ensuring accurate mineral analyses.

Dr. Jeff Sklar for providing assistance with statistical analyses and interpretations

I would also like to acknowledge both of my fellow graduate students, Breanna Modica, and Allison Mullin, for their genuine support and willingness to lend advice.

Undergraduate students involved with the Nutrition Research Enterprise during winter 2016 to spring 2018 have contributed many hours of service towards the preparation, husbandry, and analyses within my project - to which I am grateful. Two students in particular have worked with me very closely throughout my project, and have my utmost gratitude for their contributions to my research. I am grateful to Claudia Mendez, as she has devoted countless hours to the preliminary trials leading up to my study - which has included her time during academic holidays. Sirena Chu, although afraid of crickets at the beginning of my project, has been heavily involved in the bulk of my laboratory analyses, and has lead the development of digestion protocols. I am grateful for her dedication to seeing this project to completion.

Additionally, I would like to extend my gratitude to the financial support I was granted from both the College of Agriculture, Food and Environmental Sciences and the Animal Science department.

Finally, I sincerely thank my parents and sisters for their constant support in each and every one of my endeavors, including this one. 


\section{TABLE OF CONTENTS}

LIST OF TABLES. ............................................................................................................................ vii

LIST OF FIGURES........................................................................................................................... viii

LIST OF ABBREVIATIONS ................................................................................................................

CHAPTER

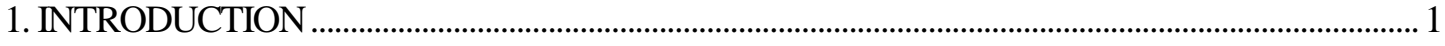

2. LITERATURE REVIEW ............................................................................................................ 3

2.1 Overview of Acheta domesticus gastrointestinal tract anatomy, morphology, and physiology ..... 3

2.2 Methods for improving nutrient profiles of feeder insects .................................................................... 4

2.2.1 Calcium supplementation .................................................................................................. 6

2.2.2 Vitamin A and carotenoid supplementation ........................................................................... 9

2.2.3 Comparing mineral content of non-supplemented crickets to insectivore requirements.... 11

2.2.4 Addition of dietary omega-3 fatty acids to gut-loading diets.................................................. 12

2.3 Challenges and considerations for gut-loading crickets.................................................................... 13

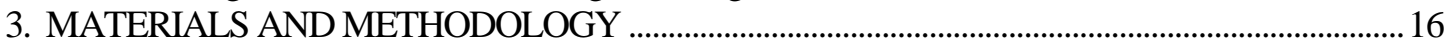

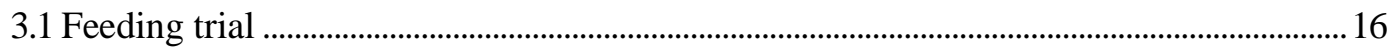

3.2 Acheta domesticus morphometrics .................................................................................... 17

3.3 Sequential determination of dry matter and ash ..................................................................... 18

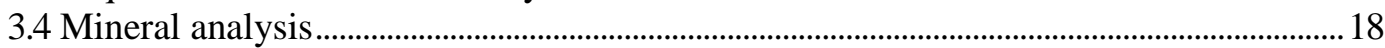

3.4.1 Sample preparation via microwave digestion............................................................. 18

3.4.2 Mineral quantification via inductively coupled plasma spectroscopy (ICP)......................... 19

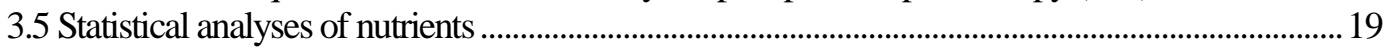

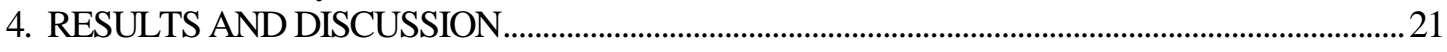

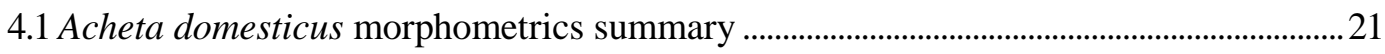

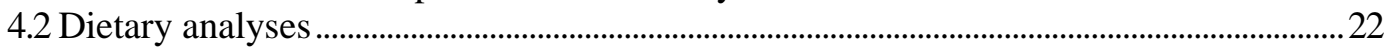

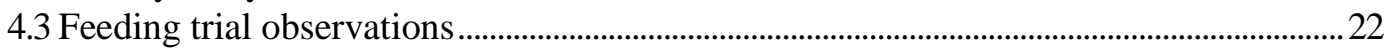

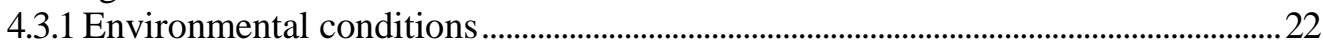

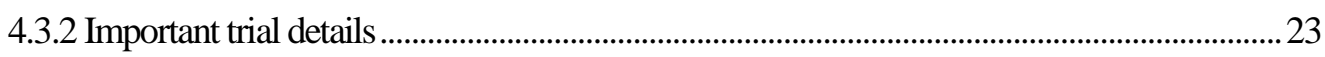

4.4 Cricket composition............................................................................................................. 24

4.4.1 Analytical results .......................................................................................................... 24

4.4.2 Measured cricket concentrations compared to insectivore requirements .............................. 24

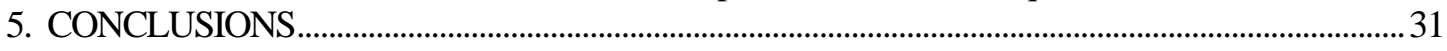

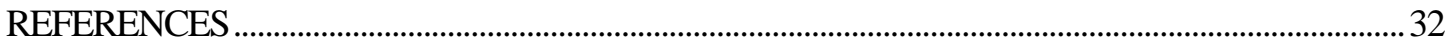




\section{LIST OF TABLES}

Table

1. Summary of references providing calcium, phosphorus, and calcium to phosphorus ratio values on listed insects. Corresponding age, sample size $(n)$, diet, time fed provided if information is available. All values expressed on a dry matter basis..

2. Summary of references providing vitamin $A$ and beta-carotene values on listed insects. Corresponding age, sample size (n), diet, time fed provided if information is available. All values expressed on a dry matter basis, unless otherwise indicated.

3. Reference dry matter, ash, macro and trace mineral content of non-supplemented crickets (Acheta domesticus). All values, except for dry matter, are reported on a dry matter basis.47

4. Wavelength used to quantify corresponding mineral during inductively coupled plasma spectroscopy (Ultima 2; ICP Analyst 5.4; Horiba Scientific, Edison, NJ) ..................................................... 48

5. Mean mass (g) \pm standard error (SE) of whole crickets and crop

6. General linear model results using crop weight as the response variable. Degrees of freedom $($ df), F-value (F) and probability ( $P$-value) are reported. Factors considered significant when $\mathrm{P} \leq 0.05$.

7. Mean mass (g) \pm standard error (SE) of whole crickets and components of the gastrointestinal tract.

8. Macronutrient, amino acid, fatty acid, and structural carbohydrate composition of maintenance and supplemented gut-loading cricket diets. All values, except dry matter, are expressed on a dry matter basis.

9. Mineral and ash composition of maintenance and supplemented gut-loading cricket diets.................52

10. Vitamin composition of maintenance and supplemented gut-loading cricket diets. All values are expressed on a dry matter basis.

11. Mean nutrient composition $( \pm \mathrm{SE})$ at each time point for maintenance and supplemented gut-loading cricket diets. Significant differences $(P \leq 0.005)$ between diets are denoted $(*)$. All values, except dry matter, reported on a dry matter basis. Calcium values within the supplemented diet are significantly different when a superscript letter is not shared.

12. General linear model results using nutrients (dry matter, ash, or minerals) as the response variable. Degrees of freedom (df), F-value $(\mathrm{F})$ and probability ( $P$-value) are reported. Factors considered significant when $P \leq 0.005$, and denoted $(*)$.

13. Listed macromineral and trace mineral requirements of and the measured minerals achieved in adult Acheta domesticus offered either a maintenance or supplemented diet for $48 \mathrm{~h}$. All values are expressed on a dry matter basis 


\section{LIST OF FIGURES}

Figure

1. Gryllus bimaculatus gastrointestinal tract. (A) Entire unfolded digestive tract of an adult female. (B) Cross section of a caecum. (C) Cross section at the base of a caecum showing the filter formed from the cecal folds. (D) Cross section of ileum showing the finger-like invaginations. (E) Dorsal view of the double loop formed in the regions ventriculus to colon. All components of the tract except the ventriculus (midgut) and ileum (hindgut) are lined with an impermeable cuticle that is shed upon molting (Woodring \& Lorenz, 2007).

2. Enclosure used for trials. Crickets (Acheta domesticus) were kept in plastic totes. Two feed dishes on the left contained experimental diet, and the two dishes on the right contained deionized water. The diet pictured is the supplemented diet. The dishes containing water were fitted with stainless steel wire cloth to provide a substrate for crickets to walk on. Paper egg flats were included in the enclosure to provide shelter and crawl space, and have been lifted from the horizontal position in this image.

3. Cricket sample processing diagram. Dry matter and ash determination was sequential, utilizing $1.0 \mathrm{~g}$ dried, ground samples in duplicate. Mineral analysis utilized $0.5 \mathrm{~g}$ samples, in duplicate, for inductively coupled plasma spectroscopy.

4. Summary of high and low temperature $\left({ }^{\circ} \mathrm{C}\right)$ measurements throughout the feeding trial. The temperature suggested to support regular feeding in Acheta domesticus is 28 to $35 \pm 0.5^{\circ} \mathrm{C}$ (Clifford \& Woodring, 1990; Finke \& Oonincx, 2014; Livingston et al., 2014; Roe et al., 1980; Woodring et al., 1977).

5. Line plot of mean dry matter (DM, \%) by time (h). Supplemented diet $=(-)$ and maintenance diet $=(--)$. Significant differences $(\mathrm{P} \leq 0.005)$ between mean values within a time point are denoted $(*)$.

6. Line plot of mean ash $(\%, \mathrm{DMB})$ by time (h). Supplemented diet $=(-)$ and maintenance diet $=(--)$. Significant differences $(\mathrm{P} \leq 0.005)$ between mean values within a time point are denoted $(*)$.

7. Line plot of mean calcium $(\mathrm{Ca}, \% \mathrm{DMB})$ by time (h). Supplemented diet $=(-)$ and maintenance diet $=(--)$. Significant differences $(\mathrm{P} \leq 0.005)$ between mean values within a time point are denoted $(*)$. Values within the supplemented diet are significantly different when a superscript letter is not shared.

8. Line plot of mean phosphorus (P, \% DMB) by time (h). Supplemented diet $=(-)$ and maintenance diet $=(-)$. Significant differences $(\mathrm{P} \leq 0.005)$ between mean values within a time point are denoted $(*)$.

9. Line plot of mean calcium to phosphorus ratio by time (h). Supplemented diet $=(-)$ and maintenance diet $=(--)$. Significant differences $(P \leq 0.005)$ between mean values within a time point are denoted $(*)$.

10. Line plot of mean potassium (K, \% DMB) by time (h). Supplemented diet $=(-)$ and maintenance diet $=(--)$. Significant differences $(\mathrm{P} \leq 0.005)$ between mean values within a time point are denoted $(*)$.

11. Line plot of mean magnesium $(\mathrm{Mg}, \% \mathrm{DMB})$ by time (h). Supplemented diet $=(-)$ and maintenance diet $=(--)$. Significant differences $(\mathrm{P} \leq 0.005)$ between mean values within a time point are denoted $(*)$.

12. Line plot of mean sodium ( $\mathrm{Na}, \% \mathrm{DMB})$ by time (h). Supplemented diet $=(-)$ and maintenance diet $=(--)$. Significant differences $(P \leq 0.005)$ between mean values within a time point are denoted $(*)$.

13. Line plot of mean sulfur (S, \% DMB) by time (h). Supplemented diet $=(-)$ and maintenance diet $=(--)$. Significant differences $(\mathrm{P} \leq 0.005)$ between mean values within a time point are denoted $(*)$. 
14. Line plot of mean iron (Fe, $\mathrm{mg} / \mathrm{kg} \mathrm{DMB})$ by time (h). Supplemented diet $=(-)$ and maintenance $\operatorname{diet}=(--)$. Significant differences $(\mathrm{P} \leq 0.005)$ between mean values within a time point are denoted $(*)$.

15. Line plot of mean manganese $(\mathrm{Mn}, \mathrm{mg} / \mathrm{kg} \mathrm{DMB})$ by time (h). Supplemented diet $=(-)$ and maintenance diet $=(--)$. Significant differences between mean values within a time point are denoted $(*)$

16. Line plot of mean copper, $(\mathrm{Cu}, \mathrm{mg} / \mathrm{kg} \mathrm{DMB})$ by time $(\mathrm{h})$. Supplemented diet $=(-)$ and maintenance diet $=(--)$. Significant differences $(\mathrm{P} \leq 0.005)$ between mean values within a time point are denoted $(*)$.

7. Line plot of mean zinc $(\mathrm{Zn}, \mathrm{mg} / \mathrm{kg} \mathrm{DMB})$ by time (h). Supplemented diet $=(-)$ and maintenance diet $=(--)$. Significant differences $(\mathrm{P} \leq 0.005)$ between mean values within a time point are denoted $(*)$.. 


\section{LIST OF ABBREVIATIONS}

$\mathrm{DM}=$ dry matter

$\mathrm{DMB}=$ Dry matter basis

ICP = inductively coupled plasma (spectroscopy)

$\mathrm{SE}=$ standard error 


\section{INTRODUCTION}

Captive insectivores may consume insects as part, or all, of their daily intake. Challenges feeding captive insectivores include the limited number of commercially available insects typically restricted to one adult (Acheta domesticus) and three larval beetle species (Tenebrio molitar, Zophobas morio, and Galleria mellonela), compared with the diversity of species and life stages consumed in native ranges (Ferrie et al., 2014; Finke, 2002; Livingston, Lavin, Sullivan, Attard, \& Valdes, 2014; Newbrey, Paszkowski, \& Dumenko 2013). Commercially raised crickets (Acheta domesticus) alone do not provide complete nutrition for captive insectivores, as they are a poor source of calcium and vitamin A (Barker, Fitzpatrick, \& Dierenfeld, 1998; Finke, 2002; Livingston et al., 2014; Pennino, Dierenfeld, \& Behler, 1991). A strategy to correct this nutrient imbalance involves gut-loading: supplementing feeder insects with a diet rich in key nutrients to meet intended insectivore requirements (Ferrie et al., 2014; Livingston et al., 2014). Initial gut-loading diets focused on correcting the calcium content of insect prey to prevent calcium deficiencies (Allen \& Oftedal, 1989; Livingston et al., 2014). The method has been documented to be successful with adult and nymphal crickets and indicates that a successfully ingested gut-loading diet will result in a period of peak nutrient concentration, during which the insect is intended to be offered as prey (Finke, 2003; Livingston et al., 2014). These studies resulted in industry guidelines to deliver adequate amounts of calcium (Allen \& Oftedal, 1989, Finke, 2003; Ferrie et al., 2014; Livingston et al., 2014).

Typical nutrient analysis of insect maintenance and gut-loading diets is often published by diet manufacturers. With the exception of calcium, the achieved nutrient composition of the insect prey species following the feeding of these diets according to strict protocols is not as readily available.

To determine the mineral profile of a commercially available gut-loading diet, adult ( 6 wks, $2.5 \mathrm{~cm} \mathrm{~L}$ ) crickets were offered a finely $(\leq 1 \mathrm{~mm})$ ground dry diet intended to enhance both the vitamin A compounds and calcium content for the target insectivore. While the supplemented diet is formulated to 
increase the vitamin A and carotenoid concentration delivered to insectivores (Mazuri, 2016; Odum et al., n.d.), the mineral profile of crickets offered this diet has not been examined. Analyses of crickets offered this diet over a period of $120 \mathrm{~h}$ may provide nutrient composition data for commercial feeder insect producers and feed companies, but especially captive feeding programs for insectivores of varying conservation status. The objective of this research is to examine the incremental accumulation of selected macro and trace minerals in adult crickets over $120 \mathrm{~h}$ when offered a supplemented diet intended to enhance both vitamin A compounds and calcium concentration in crickets. It is hypothesized that 1) offering the supplemented diet will produce a cricket with significantly higher calcium concentration compared to the maintenance diet, 2) the calcium concentration of adult crickets offered the supplemented diet will be highest at $48 \mathrm{~h}$ to $72 \mathrm{~h}$, and 3) both the calcium content and calcium to phosphorus ratio within supplemented crickets will meet the reported requirements (0.80 to 2.5\%, DMB) of carnivorous reptiles, omnivorous reptiles, and an insectivorous bird (Coturnix japonica) at different life stages (Nijboer, n.d.; NRC, 1994). 


\section{LITERATURE REVIEW}

\subsection{Overview of Acheta domesticus gastrointestinal tract anatomy, morphology, and physiology}

Acheta domesticus (Order: Orthoptera, Family: Gryllidae) are scavengers, feeding on mostly detritus. Evidence from as early as the Mesozoic era demonstrate Orthopteroid families consume algae, fungi, plant material, and silt (Blackith, 1987). The gastrointestinal anatomy, morphology, and physiology of the Mediterranean field cricket, Gryllus bimaculatus has been best described within Gryllidae.

Sensory stimuli from food items are primarily perceived by the palps, located around the mouth (Klein, 1982). The foregut of the cricket begins with chewing mouthparts, a pharynx, esophagus, crop, and proventriculus (Fig. 1). The thin crop membrane is expandable, and the proventriculus is lined with sclerotized teeth. A cardiac sphincter is located at the posterior end of the proventriculus, serving as a landmark where the foregut ends and the midgut begins. Comprising the midgut are the ventriculus and paired ceca, lined with a peritrophic membrane allowing for absorption of metabolites and enzyme release. The ventriculus ends with a ring seal, followed by the hindgut, consisting of the ileum, pylorus, ureter, colon, and rectum. Both the foregut and hindgut are lined with a hardened cuticle that does not allow absorption of nutrients in these gastrointestinal regions (Fig. 1; Woodring, Hoffmann, \& Lorenz, 2007; Woodring \& Lorenz, 2007).

Peristalsis and mechanical movement of the crop is controlled by a stomatogastic nervous system, originating from the frontal ganglion. Proventricular pressure mobilizes a food bolus throughout the gastrointestinal tract at a rate of $6 \mathrm{~mm} / \mathrm{h}$. The digestive enzymes documented in crickets include endoprotease, amylase, and lipase. Primary secretion of these enzymes occurs from the mucosal epithelial lining of the ceca, with both anterior and posterior transport of these enzymes occurring throughout the digestive tract (Woodring et al., 2007). 
Crickets, along with insects in general, are poikilotherms (Roe et al., 1980). Unable to thermoregulate, body temperature is dictated by ambient temperature (Roe et al., 1980). The window supporting regular metabolic process, ultimately influencing factors such as growth and feed intake, ranges from 25 to $35{ }^{\circ} \mathrm{C}$ among Acheta domesticus (Clifford \& Woodring, 1990; Roe et al., 1980). Metabolic maintenance comprises $78 \%$ of the male cricket daily energy budget (Hack, 1997).

Orthopteran species undergo hemimetabolous metamorphosis; crickets within the family Gryllidae will molt between each of the 7 to 8 instars that occur before the final molt. Time spent in each instar is dependent on many factors, including housing conditions such as temperature. Typically, crickets will stop ingesting food $24 \mathrm{~h}$ prior to molting, and both the fore- and hindgut cuticles are shed simultaneously with the exoskeleton. Eating resumes between 4 to $10 \mathrm{~h}$ following the final molt with substantial gastrointestinal fill achieved within $24 \mathrm{~h}$. In crickets that are actively consuming feed, the majority of digesta will be contained within the crop, ceca, ventriculus, and ileum (Fig. 1; Woodring et al., 2007; Woodring \& Lorenz, 2007).

\subsection{Methods for improving nutrient profiles of feeder insects}

From 1970 to late 1980 s, laboratory researchers and commercial cricket producers fed colonies various nutritionally complete pet foods with or without fresh produce (Wineriter \& Walker, 1988). Though most Gryllidae species could subsist on these diets, Wineriter and Walker (1988) reported faster maturation rates and a significant improvement in survivorship among Gryllus rubens when Purina Cricket Chow ${ }^{\circledR}$, formulated to support cricket maintenance, was offered. As a result, diets formulated to support cricket maintenance in a captive setting started to appear in the late 1980s.

Cricket maintenance diets are intended to sustain reproducing cricket colonies, but do not produce an insect that is nutritionally balanced for captive predators (Allen \& Oftedal, 1989; Livingston et al., 2014; Ogilvy, Fidgett, \& Preziosi, 2012). In the late 1980s and early 1990s, the imbalance of key nutrients 
within commercial crickets, specifically calcium, were investigated by facilities rearing captive insectivores (Allen \& Oftedal, 1989; Pennino et al., 1991; Trusk \& Crissey, 1987). As crickets were among the most widely available adult insect for feeding insectivores, strategies to correct the calcium imbalance began to develop.

Published data indicate that $A$. domesticus composition provides substantial protein, amino acids, Bvitamin, and minerals in relation to the requirement of many insectivorous species (Ferrie et al., 2014; Finke \& Oonincx, 2014). The major nutrients that feeder insects, including A. domesticus, lack include calcium and forms of pre- and pro-vitamin A (Table 1, 2, 3; Allen, 1989; Barker et al., 1998; Finke, 2002; Finke, 2015; Pennino et al., 1991). Strategies have been devised in attempt to correct the naturally occurring nutrient imbalance among commercially produced feeder insects: topical application of a supplement and feeding a supplemented diet to insects (Brenes-Soto \& Dierenfeld, 2014; Livingston et al., 2014).

Topical application of a selected supplement may be used to coat the body of the feeder insect prior to ingestion. The most common method involves a powdered supplement that can effectively be "dusted" onto insects (Livingston et al., 2014; Trusk \& Crissey, 1987). The efficacy of this strategy is variable the ability for a topical product to adhere to the exoskeleton depends on physical characteristics of both the product and the insect. Crickets may lose more than $50 \%$ of a topically dusted supplement in as little as $2.5 \mathrm{~min}$ due to grooming and movement (Li, Vaughan, \& Browne, 2009). Furthermore, Sabatini et al. (1998) reported less than $10 \%$ of a topical supplement to adhere to the body of crickets. Conversely, Michaels, Antwis, and Preziosi (2014) reported adequate calcium concentrations with respect to insectivore requirements in addition to a $1: 1$ to $2: 1 \mathrm{Ca}: \mathrm{P}$ in dusted crickets $5.5 \mathrm{~h}$ post topical supplement application. McComb (2010) reported improved serum retinol levels over a $102 \mathrm{~d}$ trial when dusting crickets compared with either gut-loading crickets or oral dosing of Bufo lemur with a supplement. Due to 
variable outcomes with the use of a topical supplement, there is not a resolute guideline for dusting invertebrates.

An alternative method implemented by Brenes-Soto and Dierenfeld (2014) involves injection of a concentrated carotenoid solution into the body of crickets. Although effective at delivering a known concentration of carotenoids to the target animal, this method may be time-consuming when performed on a large scale.

A supplemented diet intended to "gut-load" feeder insects contains highly concentrated nutrients that, when consumed and contained within the insect gastrointestinal tract, may deliver select nutrients in a quantity projected to meet the requirement of the target species (Finke, 2003; Livingston et al., 2014). Gut-loading diets are not formulated to maintain feeder insect colonies, but rather load the gastrointestinal tract to a desired capacity for key nutrients (Table 1, 2; Allen and Oftedal, 1989; Livingston et al., 2014; Woodring, 2007).

\subsubsection{Calcium supplementation}

Hypocalcemia is commonly reported in captive insectivores associated with consumption of commercially produced invertebrates (Ferrie et al., 2014; Livingston et al., 2014). The predominant concern across obligate insectivores following inadequate calcium intake is metabolic bone disease, which may present in various ways, including rickets, osteomalacia, and/or compromised reproductive success (Allen, Oftedal, \& Ullrey, 1993; Ferrie et al., 2014; Fowler, 1986; Hoby et al., 2010; NRC, 1994). Leopard geckos (Eublepharis macularius) offered crickets with a low calcium concentration $(0.2 \%$ calcium), demonstrated bone deformities and decreased bone calcium composition consistent with calcium deficiency (Allen, 1989). Additionally, live insects are a desirable food option that provides stimulus within avian rearing facilities, but do not deliver adequate calcium to growing chicks when provided as a sole food source (Anderson, 2000). While nutrient deficiencies have been documented in 
mammalian insectivores receiving inadequate nutrients from captive diets, mammalian insectivores tend to accept other foods in captivity, compensating for the nutrient inadequacies of commercially available insects (Nijboer, n.d.). It should also be noted that calcium deficiencies may be further compounded if vitamin D is deficient, typically due to a lack of ultraviolet light exposure in insectivores (Allen, 1989).

Previous work fed insects diets to deliver a supplemental calcium deposit in the insect gastrointestinal tract (Allen \& Oftedal, 1989; Finke, Dunham, \& Kwabi, 2005; Hunt Coslik, Ward, \& McClements, 2009). Allen and Oftedal (1989) confirmed via radiography that, when offered a high calcium diet, the calcium will be contained within the gastrointestinal tract. After 48 to $72 \mathrm{~h}$ of calcium loading, the gutloaded insect is fed to the insectivore (Allen \& Oftedal, 1989; Allen, Oftedal, \& Ullrey, 1993; Ferrie et al., 2014; Livingston et al., 2014). The high calcium concentration in a gut-loading diet typically leads to increased insect mortality following $72 \mathrm{~h}$ of consumption (Allen \& Oftedal, 1989; Klasing, Thacker, Lopez, \& Calvert, 2000). Hemolymph calcium homeostasis in A. domesticus is regulated by the Malpighian (renal) tubules, which are blind-ended sacs protruding from the gastrointestinal tract between the mid- and hindgut (Browne \& O’Donnell, 2018). Dietary calcium transport from the lumen midgut crosses the peritrophic membrane to cross the basolateral membrane and enter circulating hemolymph (Browne \& O'Donnell, 2018). The circulating calcium level in the hemolymph of A. domesticus has been approximated to be $200 \mathrm{nmol} / 100 \mu \mathrm{L}$ (Browne \& O’Donnell, 2018). Uptake from the hemolymph into the Malpighian tubules is facilitated by voltage-gated calcium channels on the primary cells of the Malpighian tubule (Browne \& O’Donnell, 2018). Up to 97\% of hemolymphatic calcium is stored within intracellular granules; $3 \%$ of calcium may be secreted into the lumen of the Malpighian tubules (Browne \& O’Donnell, 2018). This uptake is regulated by stimulatory (cyclic AMP) and inhibitory calcium pathways - absorption ceases when granule storage capabilities are met (Browne \& O’Donnell, 2018). In the event that calcium inhibitory pathways are activated, hemolymph may become saturated with calcium ions (Browne \& O’Donnell, 2018; Taylor, 1986). This presents an additional issue as the primary cells work to secrete stored calcium into the Malpighian lumen - effectively obstructing the hindgut and 
rectum of the cricket (Browne \& O’Donnell, 2018; Taylor, 1986). Gut-loading diets may contain greater than 10 fold the proposed maintenance level for calcium or higher (Table 1), serving as a likely explanation for eventual mortality observed with supplemented diets.

The calcium to phosphorus ratio in unsupplemented crickets is inverse (approximately 0.1:1 Ca:P) (Allen \& Oftedal, 1989). Supplementation may correct the ratio to $1: 1 \mathrm{Ca}: \mathrm{P}$; a ratio of $1: 1$ to $2: 1$ is recommended in most vertebrates (Table 1; Allen \& Oftedal, 1989; Finke, 2015; Fowler, 1986; Hunt Coslik et al., 2009; NRC, 1994; Strzelewics et al., 1985). In addition to this Ca:P balance, a dietary calcium concentration 0.8 to $2.5 \%$ may provide adequate calcium to insectivorous species (Table 3 ). This may be achieved with the addition of a supplemental calcium source, such as calcium carbonate ( $90 \%$ bioavailable in poultry) (Livingston et al., 2014; NRC, 1994).

Crickets fed a high calcium diet were more successful in delivering targeted concentration of calcium when compared to crickets dusted with a supplement (Li et al., 2009; Trusk \& Crissey, 1987; Sabatini et al., 1998). Crickets gut-loaded with a high calcium diet (10\%) significantly improved the skeletal calcium stores of fire-bellied toads (Bombina orientalis) (Michaels, Antiwis, \& Preziosi, 2015). Additionally, Locusta migratoria nymphs offered a $12 \% \mathrm{Ca}$ (as-is basis) diet for $48 \mathrm{~h}$ and dusted with a vitamin A and D supplement prevented metabolic bone disease in veiled chameleons (Chamaeleo calyptratus) (Hoby et al., 2010).

While the gut-loading method requires 48 to $72 \mathrm{~h}$ of feeding a colony of feeder insects, the supplementation of insect diets serves as an effective approach to successful delivery of key nutrients. Success attributed to this method is characterized by delivery of adequate dietary calcium (0.80 to $2.0 \%$, DMB provided by the feeder insect) and Ca:P (1:1 to 2:1) to captive insectivores (Hoby et al., 2010; Michaels et al., 2015). A resulting industry guideline states supplementation of 8 to $12 \%$ dietary calcium, 
on a dry matter basis, offered to feeder insects for 48 to $72 \mathrm{~h}$, may achieve target calcium concentrations (Table 1; Allen and Oftedal, 1989; Livingston et al., 2014).

\subsubsection{Vitamin A and carotenoid supplementation}

Vertebrates are unable to synthesize vitamin A; their requirement must be met through dietary sources (Quadro, Hamberger, Colantuoni, Gottesman, \& Blaner, 2003). Vertebrate insectivores receiving crickets as a substantial portion of the diet may be at risk for hypovitaminosis A (Ferrie et al., 2014; Koutsos, Matson, \& Klasing, 2001). Hypovitaminosis A may lead to conjunctival and secretory epithelial tissue hyperkeratosis, compromised reproductive and immune function, and impaired bone development (NRC, 1994). More recently, mucosal squamous metaplasia has been indicated as a suspected clinical presentation of hypovitaminosis A among captive amphibian populations (Rodriguez and Pessier, 2014). Lingual squamous metaplasia in particular significantly impacts an animal's ability to feed (Li et al., 2009).

Two forms of vitamin A include 1) preformed vitamin A (retinoids) and 2) provitamin A (carotenoids). Retinyl esters, forms of preformed vitamin A used in commercial feeds, are chemically synthesized or derived from animal sources, and tend to be more stable than various carotenoids (Quadro et al., 2003; Ramalho et al., 2008). Retinyl esters hydrolyze to retinol, a form of vitamin A readily available for vertebrates (Boily et al., 2003). Vitamin A supplementation with retinyl palmitate and retinyl acetate in various bird species is effective (Karadas et al., 2005; Koutsos et al., 2003; Quadro et al., 2003; Ramalho et al., 2008). Retinyl acetate has higher bioavailability in poultry than other forms of vitamin A, including carotenoids, retinol, and retinyl palmitate along with other retinyl esters (Attard, 2013; Nestler, 1948; NRC, 1994; Baker, 1995).

Plants contain provitamin A carotenoids, which are inactive vitamin A precursors until cleaved into retinal and converted to retinol in the avian large intestine mucosa (NRC, 1994; Quadro et al., 2003). 
Only plants synthesize carotenoids; animals ingest them in the diet. Plant foods and herbivorous insects are the primary sources of carotenoids in most birds (Brush, 1990). Beta-carotene has the highest bioavailability (25\%) of carotenoids in quail (Nestler, 1948; Klasing, 1998). Carotenoids also serve a role in both plumage and integumentary pigmentation (Brenes-Soto \& Dierenfeld. 2014; McGraw, Hill, Stradi, and Parker, 2002).

Insects in the Order Orthoptera, which include A. domesticus, accumulate carotenoids, but not retinoids in body fat stores. While the mechanism for carotenoid metabolism is not fully understood in Orthopteran species, carotenoid deficiency leads to blindness in Drosophila spp. (Voolstra, Kiefer, Hoehne, Welsch, Vogt, \& von Lintig, 2006). Drosophila metabolism indicates that dietary carotenoids are absorbed from the lumen of the midgut, and stored in the fat body of the insect (von Lintig, 2012). Synthesis of 3hydroxyretinal for vision accomplished by conversion of carotenoids remains the only recognized function of retinoids in insects (Voolstra et al, 2006). A requirement for carotenoids is likely - carotenedeficient diets allowed grasshoppers and locusts to reproduce, but poor growth, survival activity, and coloration were observed consequences (Dadd, 1963). Sullivan, Lavin, Livingston, and Valdes (2012) reported that only beta-carotene was detected in crickets offered gut-loading diets formulated to contain the same vitamin A activity as either retinol or beta-carotene. Other than for vision, it is suggested insects primarily utilize and store provitamin A carotenoids, but do not synthesize or utilize retinoids (Dadd, 1963; Voolstra et al., 2006). Supplementation of beta-carotene, a provitamin A carotenoid, may increase the pro-vitamin A concentration within the insect due to accumulation in both the gastrointestinal tract and body stores. Conversely, preformed vitamin A will likely remain unabsorbed and retained in the insects' gastrointestinal tract.

Current research examining gut-loading insects with preformed and/or provitamin A for captive insectivores focuses on amphibians (Ferrie et al., 2014; Livingston et al., 2014). Despite the ability for Orthoptera to utilize and store provitamin A carotenoids, the content within their body does not provide 
adequate provitamin A to insectivorous vertebrates without direct supplementation (Dadd, 1963; Pennino et al., 1991). There is evidence to indicate supplementation is effective; Odum et al. (n.d.) observed a significant increase liver retinol concentration in Anura offered crickets gut-loaded with vitamin A compounds. Wyoming toads (Bufo baxteri) exhibited increased growth rates and improved daily intake when offered vitamin A enhanced feeder crickets (Li et al., 2009). Brenes-Soto and Dierendfeld (2014) observed improved coloration with the skin of false tomato frogs (Dyscophus guineti).

The outcome of vitamin A gut-loading trials has been varied in the literature (Table 2). One speculation is the source of vitamin A included in the diet of the cricket is inedible, by either being too physically large or coated in an inedible substrate (Finke, 2005; Finke, 2015; Livingston et al., 2014). As observed by Attard (2013), a ground supplement diet ( $\leq 1.0 \mathrm{~mm}$ dia) will likely be consumed with vitamin A compounds measurable within the insect. Other considerations regarding vitamin A supplementation is the lability of the compound. The degradation of pre- and provitamin A is rapid when exposed to ultraviolet (natural) and florescent light, and is not recommended to be stored above $-20^{\circ} \mathrm{C}$ (Eitenmiller \& Landen, 1999). When suspended into a liquid solution, vitamin A compounds are prone to deterioration, but the rate of degradation may be slowed with preservatives or antioxidants (Eitenmiller \& Landen, 1999). Since a suspension has been used and administrated in a variety of methods across studies, vitamin A stability factors may influence quantification of retinoid and carotenoid compounds (Attard, 2013; Brenes-Soto \& Dierenfeld, 2014; Eitenmiller \& Landen, 1999; Finke, 2003; McComb, 2010).

\subsubsection{Comparing mineral content of non-supplemented crickets to insectivore requirements}

For comparison, Table 3 lists the macro and trace mineral requirements of insectivores against the concentrations in non-supplemented, commercially available crickets. The requirements for carnivorous and omnivorous reptiles were provided as summarized by Nijboer (n.d.). Japanese quail (Coturnix japonica) were selected here to serve as a model for insectivorous birds as they may consume insects at 
up to $42 \%$ of their overall dietary intake in the wild, and their requirements have been thoroughly researched (NRC, 1994; Wetherbee, 1961).

Non-supplemented crickets provide adequate or excess amounts of phosphorus, potassium, magnesium, sodium, iron, zinc, and selenium. Inadequate calcium (and imbalanced Ca:P), manganese and copper are

provided by non-supplemented crickets (Table 3; Allen, 1989; Barker, 1998; Nijboer, n.d.; NRC, 1994;). As previously discussed, the calcium inadequacy among commercial crickets is associated with hypocalcemia among captive insectivores (Allen et al., 1993; Ferrie et al., 2014; Fowler, 1986; Hoby et al., 2010).

\subsubsection{Addition of dietary omega-3 fatty acids to gut-loading diets}

Some insect gut-loading diets include supplemental omega-3 fatty acids, in effort to reduce serum cholesterol levels in amphibians. Lipid keratopathy (corneal lipidosis) is a condition observed in captive amphibians, characterized by cholesterol deposits that create a circular or arc-shaped white opacity over the cornea (Pessier, 2007; Shilton et al., 2001). This condition is associated with elevated serum cholesterol, particularly pertaining to increased proportions of low-density (LDL) and very low-density liproteins (VLDL) in relation to high-density lipoproteins (HDL), resulting from high amount of dietary cholesterol (Stilton et al., 2001). In comparison to prey consumed in a natural habitat, domestic crickets may have a higher cholesterol composition (0.7 to $1.7 \%$ ) (Shilton et al., 2001). An association between dietary cholesterol with corneal lipidosis in captive amphibians may be possible (Pessier, 2007; Shilton et al., 2001). Due to variable results on this relationship, more investigation is required.

Omega-3 fatty acids, such as docosahexaenoic acid (DHA) and eicosapentaenoic acid (EPA), effectively lower total serum cholesterol, LDL and VLDL levels. Additionally, omega-3 fatty acids contribute to corneal repair in various conditions, such as lipid keratopathy (Kenchegowda \& Bazan, 2010). The 
addition of omega-3 fatty acids to gut-loading diets is likely intended to support this physiological effect when a high cholesterol food, such as domestic crickets, is offered to amphibians.

\subsection{Challenges and considerations for gut-loading crickets}

Gut-loading success depends on numerous factors, such as developmental stage of the insect, physical properties of the diet, gut fill, photoperiod, ambient conditions, and time the insects are offered the diet (Finke \& Oonincx, 2014; Livingston, 2014).

Depending on the size of the animal consuming the crickets, providing a specific insect life stage may be more appropriate. Acheta domesticus are commercially available at various sizes, commonly ranging from pinhead (first instar/nymphal stage; $\leq 0.32 \mathrm{~cm}$ ) to adult (mature; $2.5 \mathrm{~cm}$ ) (Livingston, 2014). Cricket metamorphosis is hemimetabolous, involving molting through 7 to 9 instars prior to reaching maturity (Clifford \& Woodring, 1990). The amount of time spent within an instar is significantly influenced by temperature, humidity, and diet quality (Clifford \& Woodring, 1990; Finke \& Oonincx, 2014). The duration of the final and second to last instar have been cited to range from 5 to $8 \mathrm{~d}$ (Clifford \& Woodring, 1990). Additionally, growth and molting will not be synchronized among individuals within a colony (Clifford \& Woodring, 1990). A factor to consider when gut-loading nymphs includes significant reduction in food intake up to $24 \mathrm{~h}$ before molting to a subsequent instar, and complete emptying of the gastrointestinal tract upon molting, and eating may not resume for 4 to $10 \mathrm{~h}$ following the molt (Clifford \& Woodring, 1990; Woodring et al., 2007; Woodring \& Lorenz, 2007).

For dietary supplementation of crickets to be successful, physical properties of the diet must be appropriate for the life stage being fed. Allen and Oftedal (1989) reported that offering a ground diet resulted in up to $50 \%$ increased intake when compared to a pelleted feed. If the diet is ground, particle size should be $\leq 1 \mathrm{~mm}$ (dia) and homogenized in order to be consumed by nymph or adult crickets (Cohen, 2015; Finke et al., 2005; Livingston et al., 2014). Alternatively, soluble supplements may be 
suspended in a liquid, and sprayed on the insect diet (Finke, 2015).Both adult and nymph crickets can consume gel cubes and liquids (Livingston et al., 2014).

Crickets should be provided with free water as the sole moisture source. Providing produce or other moist substrates (e.g. wet cotton balls, wooden sticks, water gel cubes) to meet water intake requirements will detract from the efficacy of the gut-loading diet strategy (Trusk \& Crissey, 1987). Maximizing nutrient content within the insect is a priority, as the gastrointestinal tract mass consists approximately $13-15 \%$ and 11to13\% body weight (DMB) for cricket nymphs and adults, respectively (Attard, 2013).

Environmental conditions may significantly impact the efficacy of cricket supplementation protocols. Reduced intake in crickets has been reported if access to light, shelter, or water is restricted (Livingston, 2014). A photoperiod of 12L:12D is recommended for captive A. domesticus (Clifford, Roe, \& Woodring, 1977; Clifford \& Woodring, 1990; Finke \& Oonincx, 2014; Livingston et al., 2014) to establish a circadian rhythm. A consistent photoperiod will establish a routine cycle of hormones, which ultimately influences regular feeding behavior (Bloch, Hazan, \& Rafaeli, 2013). Additionally, a relative humidity of 25 to $50 \%$ combined with a temperature of 28 to $35 \pm 0.5^{\circ} \mathrm{C}$ is recommended to promote consumption of an available diet (Clifford et al., 1977; Finke \& Oonincx, 2014; Livingston et al., 2014; Roe, 1980). Temperatures below or above the recommended threshold may impact intake, establishing an inverse calcium to phosphorus ratio within feeder insects (Roe et al., 1980). An optimum temperature to promote growth, food consumption, and dry weight gain has been cited to be 30C (Clifford \& Woodring, 1990). The average amount of food consumed by an adult in a $30^{\circ} \mathrm{C}$ setting consumed $34 \mathrm{mg}$ of feed per day during the first 10 days of maturity. Nymphs consumed substantially less food, eating 16 to $28 \mathrm{mg}$ per day throughout the penultimate and last instar, respectively (Clifford \& Woodring, 1990).

Most supplemented diets fed require 48 to $72 \mathrm{~h}$ before the insect has been fed to a maximum gut fill (Allen \& Oftedal, 1989; Woodring, 2007). Pre-gut-loaded insects may be available in small quantities 
from, if desired, but this may be less cost-effective than gut-loading on-site. There may also be some uncertainty as to how long insects have been gut-loaded if purchased from a third party, as travel time, time on the shelf, and diet while on the shelf may be unknown. When planning to gut-load insects for feeding to insectivores, adequate maintenance, housing, and labor must be dedicated to successfully gutload the insects. 


\section{MATERIALS AND METHODOLOGY}

\subsection{Feeding trial}

Adult A. domesticus (6 wks, 2.5 cm, Armstrong's Cricket Farm, West Monroe, LA) were shipped overnight and transferred directly from shipping containers into plastic tote enclosures $(60.7 \mathrm{~cm} \mathrm{~L} \mathrm{x} 40.4$ cm W x 41.9 cm in H, 68 L Roughneck Storage Box \#2215, Rubbermaid Commercial Products LLC, Winchester, VA). A $20 \mathrm{~cm}$ x $51 \mathrm{~cm}$ window covered by stainless steel metal mesh (mesh size $0.0 .18 \mathrm{~mm}$; WireCloth size 80, Gerard Daniel Worldwide, Ontario, CA). This same mesh was cut into circles to fit snugly into the top half of a petri dish (Fig. 2;100 x $20 \mathrm{~mm}$, polystyrene tissue culture dish \#353003, Falcon ${ }^{\circledR}$ Brand, Corning, New York, 14831) to provide a porous walking surface for crickets to access $a d$ libitum deionized water $\left(\mathrm{diH}_{2} \mathrm{O}\right)$. The bottom halves of the petri dishes were used as vessels for diet distribution (Fig. 2). Paper egg flats $(30.5 \times 30.5 \mathrm{~cm})$ provided shelter and surface area for movement (Fig. 2; Livingston et al., 2014). Enclosures were supported by PVC pipe racks, located $61 \mathrm{~cm}$ from the floor.

The room in which all animals were housed was dedicated for A. domesticus utilized for this study only. A relative humidity of $50 \%$ and a 12L:12D light cycle (0700 to $1900 \mathrm{~h}, \mathrm{PDT}$ ) were maintained (Livingston et al., 2014; Clifford et al., 1977). Ambient temperature was set to $25.0^{\circ} \mathrm{C}$ (Wineriter $\&$ Walker, 1988) and the current, maximum, and minimum temperature was monitored every $24 \mathrm{~h}$ at 1800 h, PDT. Adult crickets were selected since they will no longer molt - removing the variability of feed intake that would be observed among molting nymphs.

On the date of arrival to California Polytechnic State University (29-Sep-2017), 12,000 crickets were randomly divided into two treatment groups: maintenance diet (control) or supplemented diet. Both are finely ground diets with a particle size $\leq 1.0 \mathrm{~mm}$ in diameter and were sourced from a single manufactured lot. Each treatment was represented by triplicate bins during the trial $(n=3$ per diet, 2,000 crickets per bin). During shipment crickets were provided raw white potatoes. The passage rate in $A$. 
domesticus is likely rapid, as a newly molted female offered ground food $14 \mathrm{~h}$ post-molting will have evidence of the recent digesta present in the rectum 80 min post-ingestion (Woodring \& Lorenz, 2007). To allow time for potatoes to pass, a $72 \mathrm{~h}$ wash-out period using the maintenance diet preceded the feeding trial. Crickets had ad libitum access to water and diet, which was removed and refreshed every 24 $\mathrm{h}$ at $1800 \mathrm{~h}, \mathrm{PDT}$.

A random sample of $150 \mathrm{~g}$ crickets (approximately 310 crickets) per bin and $50 \mathrm{~g}$ per diet were collected every $24 \mathrm{~h}$ between 0 to $120 \mathrm{~h}$ (02-Oct-2017 to 07-Oct-2017). Fig. 3 includes a diagram with the sampling, processing, and analyses conducted with cricket samples. Remaining crickets were transferred to a clean bin with identical arrangements. Any excreta, deceased crickets, or detached body parts were not included with the random samplings and discarded. Due to a considerable amount of excreta present in the food dishes after each $24 \mathrm{~h}$ period, daily food intake could not be accurately measured.

\subsection{Acheta domesticus morphometrics}

During a separate trial, live adult $A$. domesticus ( $n=580,6$ wks, $2.5 \mathrm{~cm}$, Armstrong's Cricket Farm, West Monroe, LA) were distributed into eight plastic tote enclosures to observe crop fill throughout the day. All crickets were offered the same maintenance diet, and crickets $(n=10)$ collected over $48 \mathrm{~h}(1800 \mathrm{~h}$ PDT on 28-Mar-17 to $1800 \mathrm{~h}$ PDT on 30-Mar-17) at three time points per day (0800, 1300, and $1800 \mathrm{~h}$ PDT). Crickets were immediately frozen $\left(-20^{\circ} \mathrm{C}\right)$ for $24 \mathrm{~h}$ prior to as-is body and crop mass determination using an analytical balance. Visual presence of digesta within the crop were noted. A general linear model used crop weight ( $\log 10$ transformation) as the response variable, and factors included sex (nominal), whole cricket weight (continuous), digesta content (nominal), time point (ordinal), date (nominal) nested within time point, and bin (nominal) (JMP Pro 13, SAS, Cary, NC). Raw crop weight data did exhibit normality or homogeneity in variance. After transformation (log base10), residual plots appeared more homogenous, but the Shapiro-Wilkes test indicated evidence against a normal distribution $(P=0.0401)$. 
To compared the total gastrointestinal tract mass to the body mass, a sample of adult crickets $(A$. domesticus) from a different supplier (Timberline, Marion, IL) were frozen $\left(-20^{\circ} \mathrm{C}\right)$ for $24 \mathrm{~h}$ prior to characterization of gastrointestinal morphology. An analytical balance was used to determine as-is mean individual body mass and respective gastrointestinal tract organ masses.

\subsection{Sequential determination of dry matter and ash}

After collection, live crickets and diets were immediately frozen $\left(-20^{\circ} \mathrm{C}\right)$ and stored for 7 mo until sample processing began. Crickets ( $75 \mathrm{~g}$, fresh weight basis) were dried to a constant mass in a forced-air drying oven at $50^{\circ} \mathrm{C}$ before grinding with a stainless steel mill through a $1 \mathrm{~mm}$ screen (Digital ED-5 Wiley Mill, Thomas Scientific, Swedesboro, NJ, 08085). The remaining crickets from an individual sample were stored in a freezer $\left(-20^{\circ} \mathrm{C}\right)$ for future vitamin analysis. Sequential gravimetric determination of DM and ash was accomplished by drying $1.0 \mathrm{~g}$ ground crickets or diets in a forced-air drying oven $\left(100^{\circ} \mathrm{C}\right)$ for 24 h (NFTA, 1993, Method 2.2.2.2) followed by $6 \mathrm{~h}$ in a muffle furnace $\left(600^{\circ} \mathrm{C}\right)$ (adapted from NFTA, 1993, Method 7) . Duplicate values within a standard deviation \pm 0.30 were accepted.

\subsection{Mineral analysis}

\subsubsection{Sample preparation via microwave digestion}

In preparation for mineral analyses, duplicate dried cricket and diet samples $(0.5 \mathrm{~g})$ were mixed with 10 $\mathrm{mL}$ trace-mineral grade nitric acid (A509-P212, Fisher Chemical, Waltham, MA) into uncovered Teflon vessels (EasyPrep Vessels, CEM Corporation, Matthews, NC) and pre-digested under a chemical fume hood for 15 min (Restivo, 2018a; Restivo, 2018b). Vessels were then covered and installed into support modules (EasyPrep support modules, CEM Corporation, Matthews, NC) and loaded in the microwave digestion system (MARS 5 ${ }^{\mathrm{TM}}$, CEM Corporation, Matthews, NC). Samples ramped to $200^{\circ} \mathrm{C}$ over $30 \mathrm{~min}$ and held at $200^{\circ} \mathrm{C}$ for 15 min under 800 psi and $1600 \mathrm{~W}$ (Restivo, 2018a; Restivo, 2018b). Wattage, temperature, and ramp-time settings were recommended by CEM technical support (personal communication, May 2018). Internal vessel temperature was monitored using a fiber optic temperature 
sensor (Probe, RTP-300 Plus \#314305, CEM Corporation, Matthews, NC), and vessels were removed from system once internal temperature was at or below $100^{\circ} \mathrm{C}$ (Restivo, 2018a; Restivo, 2018b). Digested contents were transferred to digestion vials (Ultimate Clean Cup \#UCC000-50, Environmental Express, Charleston, SC) under a chemical fume hood and diluted to $50 \mathrm{~mL}$ using $\mathrm{diH}_{2} \mathrm{O}$ (Restivo, 2018a; Restivo, 2018b).

\subsubsection{Mineral quantification via inductively coupled plasma spectroscopy (ICP)}

Digested samples were transferred to disposable test tubes $(\geq 10 \mathrm{~mL})$ for mineral analysis using inductively coupled plasma (ICP) optical emission spectroscopy (Ultima 2 Sequential Spectrometer, Horiba Jobin Yvon Inc., Edison, NJ). Results were quantified using ICP Analyst 5.4 (Horiba Jobin Yvon Inc., Edison, NJ). The instrument was calibrated using known standards of ten selected minerals, including $\mathrm{Ca}, \mathrm{P}, \mathrm{K}, \mathrm{Mg}, \mathrm{Na}, \mathrm{Cl}, \mathrm{Fe}, \mathrm{Zn}, \mathrm{Mn}, \mathrm{Cu}, \mathrm{S}$ at designated wavelengths of detection (Table 4). Samples were autoinjected in triplicate and rinsed with 5 to $7.5 \%$ nitric acid between tubes. Analytical parameters include a power of $1200 \mathrm{~W}$, pump speed of 20 revolutions $/ \mathrm{min}$, a flow rate of $1 \mathrm{~mL} / \mathrm{min}$. The inductively coupled coil operated at a frequency of $40.8 \mathrm{~Hz}$, plasma gas flow rate was $14 \mathrm{~L} / \mathrm{min}$, and nebulizing pressure was 2.8 bars. All samples were analyzed during a single run. To verify the integrity of the mineral quantification throughout the run, 1) standards of known composition were analyzed after every 20 samples, 2) in each set of 20 samples, two random samples were replicated, and 3) a known standard for tomato leaves (NIST 1573A) were analyzed. Duplicate values within $20 \%$ difference were accepted.

\subsection{Statistical analyses of nutrients}

An analysis of variance was implemented via a general linear model to individually examine selected nutrient concentrations. Response variables included the nutrients of interest (DM, ash, $\mathrm{Ca}, \mathrm{P}, \mathrm{K}, \mathrm{Mg}, \mathrm{Na}$, Fe, Zn, Mn, Cu, S). Factors included 1) diet, 2) time (ordinal), 3) an interaction between diet and time, and 4) bin nested within diet as a random effect. To reduce the occurrence of a Type I error, a Bonferroni 
correction was used to establish significant differences among dry matter and ash values when $P \leq 0.025$ and among mineral values when when $\mathrm{P} \leq 0.005$. Assumptions of normality and homogeneity of variance was examined using the Shapiro-Wilkes test and residual plots. To determine differences between diets at specific time points, a least squared means contrast test was conducted. Observation of differences between mean calcium concentrations across time within the supplemented diet was conducted using a Tukey's test $(P \leq 0.05)$ (JMP Pro 13, SAS, Cary, NC). 


\section{RESULTS AND DISCUSSION}

\subsection{Acheta domesticus morphometrics summary}

Acheta domesticus (acquired 28-Mar-17) had an average body mass of $0.4846 \mathrm{~g}$ (as-is basis) (Table 5). Using the average dry matter content for crickets collected from the feeding trial (28.42\%) across the maintenance diet treatment, the body mass on a dry matter basis is $1.7051 \mathrm{~g}$. Both body mass and the presence of digesta within the crop were significant factors in relation to crop weight $(P<0.0001)$. Sex, bin, and time were not significant factors (Table 6).

The crop was measured due to ease of dissecting out this organ for prelimary information about gastrointestinal tract fill throughout the day. Functioning as a storage site for recently foraged food items (Woodring et al., 2007), the presence or absence of digesta in the crop at the designated sampling points $(0800,1300,1800 \mathrm{~h})$ was visually assessed. Since time was not a determining factor in crop weight $(P=$ 0.2972), $1800 \mathrm{~h}$ was established as the collection time for the primary feeding trial.

Gastrointestinal characteristics of crickets are provided in Table 7. Assuming the average cricket dry matter content of $28.42 \%$ when offered a maintenance diet across all time points, the mean total gastrointestinal tract mass of the A. domesticus sampled comprises $10.91 \%$ (DMB) of the cricket body. This is numerically similar to the estimation that the gut-loaded contents represent approximately 11 to $13 \%$ (DMB) of the adult domestic cricket (Attard, 2013).

Overall average A. domesticus body mass was lower in crickets received for gastrointestinal measurements. This may be due to a smaller sample size as well as differences in husbandry techniques; these crickets were purchased from a pet store and housed under unknown conditions. Based on gross comparison of mass, the crop, ceca, ventriculus, and hindgut were the organs contributing the most mass in respect to the total gastrointestinal tract (Table 7). While digesta content was not characterized within 
each of these organs, these measurements are consistent with indications by Woodring et al. (2007) that suggest gut fill is accomplished at these sites.

\subsection{Dietary composition}

Macronutrients (dry matter and ash) of the two diets exceeded the manufacturer's reported values (Table 8; Mazuri, 2016; Mazuri, 2017). Minerals analyzed met or exceeded the approximate analysis provided by the manufacturer, with the exception of sodium, iron, zinc, and copper, each of which was lower than the typical analysis (Table 9; Mazuri, 2016; Mazuri, 2017). Vitamin measurements from approximate analyses are provided, though not measured in the current study (Table 10).

Across both diets, sodium and copper were lower in both diets, in comparison to the approximate analyses provided by the manufacturer. Iron, phosphorus, and zinc measured lower in the supplemented diet only, with phosphorus and zinc marginally below the approximate value (Table 9). Lower measured values may be due to laboratory error or unavoidable variability within the samples.

\subsection{Feeding trial observations}

\subsubsection{Environmental conditions}

The room in which all crickets were housed maintained a 12L:12D light cycle (0700 to $1900 \mathrm{~h}, \mathrm{PDT})$ and a relative humidity of $50 \%$. The mean low temperature value was $23.6^{\circ} \mathrm{C}$, and the high temperature mean was $25.5^{\circ} \mathrm{C}$. The temperature did not fall below $22.7^{\circ} \mathrm{C}$ or rise above $27.0^{\circ} \mathrm{C}$ throughout the duration of the trial (Fig. 4).

A temperature range of 28 to $35 \pm 0.5^{\circ} \mathrm{C}$, and ideally a temperature gradient within an enclosure is recommended to promote feeding within crickets (Clifford et al., 1977; Finke \& Oonincx, 2014; Livingston et al., 2014; Roe et al., 1980). The maximum temperature achieved throughout the feeding trial $\left(27^{\circ} \mathrm{C}\right)$ is $1^{\circ} \mathrm{C}$ lower than the minimum recommendation (Fig. 4). It is possible that the relatively low 
environmental temperature may have impacted cricket intake levels (Roe et al., 1980). Roe et al. (1980) observed a $50 \%$ intake reduction during the first half of the last instar of A. domesticus at $25^{\circ} \mathrm{C}$ compared to $30{ }^{\circ} \mathrm{C}$, but in the second half of the instar, there was no difference in intake. Additionally, Harrison \& Fewell (1995) determined that the threshold for feeding in two-striped grasshoppers (Melanoplus bivattutus, Family: Acrididae) is $25^{\circ} \mathrm{C}$.

While the crickets were housed in an isolated room containing no other animals, the thermostat controlling the corresponding section of the building directly impacted animals in neighboring rooms with specific temperature requirements. Future studies should plan to incorporate portable heating lamps that may be used within the room housing crickets (Livingston et al., 2014).

\subsubsection{Important trial details}

At the beginning of the feeding trial, 2,000 crickets were randomly placed into each of the six enclosures. Upon arrival, a hole was inadvertently punctured into one of the shipment containers, allowing $<1,000$ of the crickets to escape. This container was assigned to one of the enclosures housing crickets assigned the maintenance diet, and crickets in this enclosure were exhausted after $72 \mathrm{~h}$ of collection.

During the $96 \mathrm{~h}$ collection, cricket populations were exhausted from two of the enclosures housing crickets on the supplemented diet. Although the original count of 2,000 crickets per enclosure was intended to overestimate the number of crickets that would be utilized throughout the trial, it is presumed that the high concentrations of calcium in the supplemented diet led to high mortality by $96 \mathrm{~h}$ (Allen \& Oftedal, 1989; Klasing et al., 2000). 


\subsection{Cricket composition}

\subsubsection{Analytical results}

Mean dry matter, ash, and mineral content of crickets offered both the maintenance and supplemented diet over the $120 \mathrm{~h}$ feeding trial are displayed in Table 11 and Fig. 5 to 17 . General linear model results, using nutrient as the response variable, are presented in Table 12. The amount of time crickets were offered the diet had a significant impact on dry matter $(P=0.0029)$, magnesium $(P=<0.0001)$, zinc $(P<$ 0.001), copper $(P=<0.0001)$ and sulfur $(P<0.0001)$ concentrations. A significant interaction was present between time and diet with ash $(P=0.0002)$, calcium $(P=<0.0001)$, phosphorus, $(P=0.0003)$ calcium to phosphorus ratio $(P=<0.0001)$, potassium $(P=0.0003)$, sodium $(P=<0.0001)$, manganese $(P=<0.0001)$. Among the factors tested, no significant differences were observed with iron (Table 12). No differences were found within diet individually, or with bin as a random effect nested within diet.

All response variables followed a normal distribution and displayed homogenous variance except for the raw calcium (\%) data and calcium to phosphorus ratio (Ca:P, \%) data (Shapiro Wilkes test $P<0.0001$ ). After an arc sine transformation, both calcium and Ca:P data were neither normal (Shapiro Wilkes test $P$ $<0.0001$ ) or within equal variance. A two-sample t-test, followed by a nonparametric Mann-Whitney test performed on both the untransformed and arc sine transformed data by diet, produced consistent p-values of $<0.0001$ on each of the eight tests (JMP Pro 13, SAS, Cary, NC), indicating that the non-normality of these data were not producing spurious results.

\subsubsection{Measured cricket concentrations compared to insectivore requirements}

The supplemented diet is formulated to enhance pre- and provitamin A compounds, and calcium concentrations within gut-loaded crickets delivered to an insectivore. This is achieved by including sources of vitamin A compounds (fish meal, fish oil, spirulina algae meal, and vitamin A acetate) and calcium (calcium carbonate) in the ground diet (Mazuri, 2016). While evidence supports the ability for fish oil and spirulina to significantly improve the liver retinol content of Wyoming toads (Anaxyrus 
baxteri), mineral composition of crickets offered this diet has not been reported (Odum et al., n.d.). The crickets utilized for this study were also only gut-loaded for $30 \mathrm{~min}$ (Odum et al., n.d.), which is a shorter period of time than what is traditionally recommended (Clifford et al, 1977; Finke \& Oonincx, 2014; Livingston et al., 2014). Analyses of crickets offered the supplemented diet provide a reference for mineral composition of crickets fed this diet under industry guidelines. For comparison, Table 13 lists the macro and trace mineral requirements of insectivores against the concentrations achieved in crickets offered the supplemented diet for $48 \mathrm{~h}$. While guidelines for reptile requirements are provided, mineral deficiency and toxicity has not been researched to the same extent as poultry (Nijboer, n.d.; NRC, 1994).

Both the dry matter and ash content of the crickets on either diet were consistent with previously measured values among supplemented crickets (Table 3,11). There was no difference in dry matter content throughout the trial (Table 11; Fig.5). The ash content of supplemented crickets was significantly higher at $48 \mathrm{~h}$ compared to crickets on the maintenance diet $(P<0.0001$, Table 11 ; Fig. 6$)$. Since ash is a measure of all inorganic matter, this datum point was likely influenced by elevated concentrations of calcium and sodium at $48 \mathrm{~h}$.

The supplemented diet provided $11.32 \%$ (DMB) calcium, and the maintenance diet provided $1.58 \%$ (DMB) calcium, as analyzed (Table 9). As hypothesized, the calcium content of crickets offered the supplemented diet significantly differed from the maintenance diet at 48, 72, 96, and $120 \mathrm{~h}$, and the measured calcium content reached a peak at $0.63 \%$ (DMB) at $48 \mathrm{~h}$ (Table 11; Fig. 7). This peak concentration was not significantly different from the mean calcium concentrations at either 24 or $72 \mathrm{~h}$ (Table 11; Fig. 7).

Although at a supplemented level of $11.32 \%$ (DMB), which was $616.5 \%$ higher than the maintenance diet value, crickets did not reach the desired calcium concentration of 0.8 to $2.5 \%$ (DMB) (Table 9, 13). This finding was not consistent with other published studies, which report achieving $0.8 \%$ calcium or higher in 
supplemented crickets offered 7.15 to $12.14 \%$ (DMB) dietary calcium for 48 h (Table 1; Allen \& Oftedal, 1989; Anderson, 2000). The Ca:P values followed the trend observed with calcium (Table 11; Fig. 9).

The low levels of measured calcium, in respect the requirement of insectivores (Table 13), indicated that the supplemented diet did not effectively gut-load adult crickets with calcium. Feeding a cricket with this measured calcium value and corresponding $\mathrm{Ca}: \mathrm{P}$ ratio $(0.52 \%, \mathrm{DMB})$ may increase the risk of hypocalcemia in the target insectivore. The low calcium content in the supplemented crickets may have been influenced by a variety of factors. First, the temperature suggested to support regular feeding is 28 to $35 \pm 0.5^{\circ} \mathrm{C}$ (Clifford \& Woodring, 1990; Finke \& Oonincx, 2014; Livingston et al., 2014; Roe et al., 1980; Woodring et al., 1977). Throughout the duration of the trial, the highest ambient temperature recorded was $27.0^{\circ} \mathrm{C}$ (Fig. 4). Since the crickets were consistently housed at a suboptimal temperature, it was possible that intake levels were depressed. As stated previously, Roe et al. (1980) observed a 50\% reduction in food consumption among A. domesticus in the first half of the final instar when housed at 25 ${ }^{\circ} \mathrm{C}$ compared to $30{ }^{\circ} \mathrm{C}$. Second, crickets are nocturnal scavengers. Future feeding trials may want to incorporate intake data during several time points throughout the dark cycle, as crickets were only sampled throughout the light cycle during this study. Lastly, paper pulp egg flat consumption was anecdotally observed. Characterization of quantity ingested in future studies is recommended.

Phosphorus concentration within crickets were within expected ranges, at $1.01 \%$ (DMB) on the maintenance diet and 1.02\% (DMB) on the supplemented diet at $48 \mathrm{~h}$ (Table 9). These concentrations meet the requirement for all insectivores listed (Table 13). There was a significantly higher concentration of phosphorus within the maintenance treatment at $72 \mathrm{~h}(P=0.0004$, Table 11; Fig. 8). Measured phosphorus values were anticipated, but it should be disclosed that enclosures, feed, and water dishes were washed with Tergazyme (Alconox, Inc., White Plains, NY) detergent, cited to contain 7.6\% phosphorus by weight. 
Across both diets, potassium did not differ (Table 11; Fig 10). At concentrations of $1.26 \%$ (DMB) in maintenance crickets, and $1.22 \%$ (DMB) in supplemented crickets, potassium exceeded the minimum insectivore requirement of $0.4 \%$ (DMB) (Table 13). Potassium content is $205 \%$ and $215 \%$ higher than the minimum requirement in the supplemented crickets and maintenance crickets, respectively (Table 13). The measured concentrations are similar to the reported value of $1.27 \%$ (DMB) in non-supplemented crickets (Allen, 1989; Table 3). Potassium is not tolerated as well as other electrolytes, such as sodium, but whether or not this concentration will be detrimental to insectivores is unclear (Underwood \& Suttle, 1999).

Magnesium concentrations did not differ between treatments (Table 11; Fig. 11). The measured values in crickets across both diets was $0.13 \%$ (DMB), and exceeded the requirement for carnivorous reptiles and quails by 160 to $333 \%$ (Table 13). The magnesium content of both diets was $35 \%$ lower than the omnivorous reptile requirement (Table 13). Homeostatic mechanisms in vertebrates will typically regulate magnesium absorption to prevent deficiency or toxicity at these levels (Underwood \& Suttle, 1999). The magnesium concentration of $0.13 \%$ (DMB) in measured crickets (Table 13) is not likely a concern, as symptoms of toxicity occur at levels of 0.57 to $0.64 \%$ in chicks, and 1.12 to $1.96 \%$ in mature chickens (NRC, 1994).

Sodium concentrations increased throughout the trial, and the content within supplemented crickets significantly differed from maintenance crickets at 48, 72, 96, and $120 \mathrm{~h}$ (Table 11; Fig. 12). While the concentration of sodium in the supplemented cricket was 140 to $220 \%$ higher than the reptilian and quail requirements, respectively, sodium regulated through homeostasis and may be tolerated at the reported levels (Table 13; Underwood \& Suttle, 1999). Sodium content for the maintenance diet $(0.44 \%, \mathrm{DMB})$ and supplemented diet $(0.48 \%, \mathrm{DMB})$ were well below the listed toxic levels in chickens, but exceed reported toxic concentrations in immature turkey and ducks (Table 13; NRC, 1994). At concentrations of 
$0.40 \%$ sodium, immature turkey may experience reduced body weight and/or mortality; immature ducks may experience reduced body weight (NRC, 1994). Although the same detergent that contained trace amounts of phosphorus also listed sodium present at 20 to $30 \%$ by weight the high reported sodium values are likely due to the natural composition of a domestic cricket. A sodium concentration of $0.50 \%$ (DMB) was reported in non-supplemented crickets, which is numerically similar to the measured concentrations in crickets in the current study (Allen, 1989; Table 3, 13). If the intention is to feed supplemented crickets to immature avian species, a recommendation would include incorporating foods containing lower sodium concentrations in the overall diet.

Sulfur within measured crickets was significantly higher in the supplemented diet at $72 \mathrm{~h}(P=0.0029$, Table 11; Fig., 13). The measured sulfur values of $0.68 \%$ (DMB) in the maintenance diet and $0.70 \%$ (DMB) in the supplemented diet are below the levels of sulfate toxicity reported in chicks $(1.4 \%)$ and chickens $(0.81 \%)$ (NRC, 1994). Although there are no listed reference values for comparison of measured sulfur to other insects or insectivore requirements, it should be noted that the detergent used for cleaning lists sulfur concentration at 1210 ppm, which may have had an unspecified influence on analyzed values.

When analyzing minerals, it is important to minimize sources of contamination such as dust or extraneous debris. To further reduce possible sources of contamination, it may be recommended that a mineral-free detergent is used for all aspects of cleaning any instruments or labware that may contact samples for analysis. A detergent containing sodium, phosphorus, and sulfur was utilized for cleaning of enclosure surfaces, feed dishes, and water dishes, which may have been a potential factor for mineral contamination. Tap water was used for rinsing enclosure surfaces, which may have also introduced an unknown concentration of various minerals to the enclosure. Additionally, no nutrient profile was available for the paper pulp egg flats that were provided as crawl space for the crickets in the current 
study. While crickets were anecdotally observed to chew on flats, especially if moistened with water, it would have been ideal to obtain a mineral profile on the edible substrate that was used for housing,

Iron values did not differ across treatments (Table 11; Fig. 14). The iron requirement was met, across both diets, for carnivorous reptiles and breeding quail (Table 13). The supplemented diet contained $72.2 \mathrm{mg} / \mathrm{kg}$ iron (DMB), which was 40to 64\% deficient with respect to the starting/growing quail and omnivorous reptile requirements (Table 13). Low iron intake increases the risk for anemia - a supplementary source of iron (e.g. oral supplement or iron-rich produce) may be warranted to meet the juvenile quail and omnivorous reptile requirements (Underwood \& Suttle 1999).

Manganese steadily decreased within the supplemented crickets over time, and measured significantly lower than maintenance crickets at 24, 48, 72, 96, and $120 \mathrm{~h}$ (Table 11; Fig. 15). Measured values were $50.3 \mathrm{mg} / \mathrm{kg}(\mathrm{DMB})$ in maintenance crickets and $39.2 \mathrm{mg} / \mathrm{kg}$ (DMB) supplemented crickets. These concentrations exceed the requirement in carnivorous reptiles and starting/growing quail, but may not be of concern for toxicity, as a manganese value of $2000 \mathrm{mg} / \mathrm{kg}$ has been indicated to be the safe dietary limit in poultry (NRC, 1980). Inadequate manganese for breeding quail and omnivorous reptiles were provided by supplemented crickets at 35 to $74 \%$ lower than the requirements, respectively (Table 13). It is unclear if the concentrations measured will lead to clinical deficiency; although it is advised that omnivorous reptiles receive adequate manganese from other components of the diet.

A point of interest is the potential competition for sodium and manganese absorption within the gastrointestinal system of the crickets. The sodium content of the supplemented crickets appeared to steadily increase, and achieve a significantly higher concentration compared to maintenance crickets from 24 to $120 \mathrm{~h}$. The manganese concentration within supplemented crickets followed an opposing trend, with a steady decline in concentration that was significantly lower than maintenance crickets from 24 to $120 \mathrm{~h}$. Although dietary mineral absorption in Acheta domesticus is not fully understood, competition for 
absorption between sodium and manganese may have occurred as excess dietary sodium may antagonize manganese absorption in humans (Davidsson, 1991).

Copper values did not differ across diet (Table 11; Fig. 16). Measured copper values were $27.7 \mathrm{mg} / \mathrm{kg}$ (DMB) in maintenance crickets and $26.9 \mathrm{mg} / \mathrm{kg}(\mathrm{DMB})$ in supplemented crickets, which exceeded the nutrient requirements for all listed insectivores except starting/growing quail (Table 13). The measured copper values were likely within an acceptable range of tolerance, as concentrations of 50 to $806 \mathrm{mg} / \mathrm{kg}$ are associated with toxicity in poultry (NRC, 1994). The supplemented crickets contained 55\% less copper than the listed starting and growing quail requirement (Table 13); additional sources of copper would be recommended to include in the diet of juvenile quail receiving supplemented crickets.

Zinc was significantly lower than the maintenance treatment at $120 \mathrm{~h}(P=0.0047$; Table 11 ; Fig. 17). Measured values exceed the requirements for listed insectivores (Table 13). Zinc concentrations were likely within an acceptable range of tolerance, as concentrations of 800 to 4,000 $\mathrm{mg} / \mathrm{kg}$ are associated with toxicity in poultry (NRC, 1994). 


\section{CONCLUSIONS}

Offering a diet enhanced with vitamin A, omega-3 fatty acids, and high calcium (11.32\%, DMB) to adult crickets, significantly increased the calcium content within the insect between 24 to $120 \mathrm{~h}$ of feeding when compared to a maintenance diet. Additionally, the highest calcium concentration $(0.63 \%)$ was achieved at $48 \mathrm{~h}$ of feeding the supplemented diet to the crickets. This concentration did not, however, reach a target level of 0.8 to $2.5 \%$ calcium $(\mathrm{DMB})$ or provide a $1: 1 \mathrm{Ca}: \mathrm{P}$ ratio, as required by insectivores.

Supplemented crickets yielded a mineral profile that met most, but not all requirements, for carnivorous reptiles, omnivorous reptiles, and an omnivorous bird in different life stages. Among measured minerals, phosphorus, magnesium, iron, copper and zinc requirements were met. Sodium and potassium were potentially provided in excess, and may pose a risk for toxicity if the supplemented crickets are offered as the primary food source. The calcium (with an inverse corresponding Ca:P ratio), iron, and manganese requirements were not met with supplemented crickets, and may potentiate the risk for deficiency if the supplemented cricket is offered as the sole source of nutrition. Additional sources of calcium, iron, and manganese are crucial if feeding the supplemented crickets.

The primary concern relating to insectivore mineral nutrition is preventing or correcting hypocalcemia. Either process may begin with providing a diet containing an appropriate calcium and phosphorus balance through select invertebrates. Although industry guidelines were adhered to provide a more complete insect, the gut-loading potential of the crickets may have been optimized with a heating source to provide a warmer environment, thus providing ideal conditions to promote regular feeding behavior. Other factors that may have dampened the gut loading capabilities include the unknown degree to which paper carton egg flats were consumed, and the fact that crickets were sampled during the light cycle. 


\section{References}

Allen, M. E. (1989). Nutritional aspects of insectivory. (Dissertation). Michigan State University, United States.

Allen, M. E., \& Oftedal, O. T. (1989). Dietary manipulation of the calcium content of feed crickets. Journal of Zoo Wildlife Medicine, 20, 26-33.

Allen, M. E., Oftedal, O. T., \& Ullrey, D. E. (1993). Effect of dietary calcium concentration on mineral composition of fox geckos (Hemidactylus garnoti) and Cuban tree frogs (Osteopilus septentrionalis). Journal of Zoo and Wildlife Medicine, 24, 118-128.

Anderson, S. J. (2000). Increasing calcium levels in cultured insects. Zoo Biology, 19, 1-9. doi: 10.1002/(SICI)1098-2361(2000)19:1<1::AID-ZOO1>3.0.CO;2-F

Arbuckle, K. (2009). Influence of diet on mineral composition of crickets used as prey for captive amphibians, specifically Hylidae. (Master's thesis). University of Glasgow, Scotland.

Attard, L. (2013). The development and evaluation of a gut loading diet for feeder crickets formulated to provide a balanced nutrient source for insectivorous amphibians and reptiles. (Master's thesis). University of Guelph, Canada.

Banjo, A. D., Lawal, O. A., \& Songonuga, E. A. (2006). The nutritional value of fourteen species of edible insects in southwestern Nigeria. African Journal of Biotechnology, 5, 298-301. doi: 10.5897/AJB05.250

Barker, D., Fitzpatrick, M. P., \& Dierenfeld, E. S. (1998). Nutrient composition of selected whole invertebrates. Zoo Biology, 17, 123-134. doi: 10.1002/(SICI)1098-2361(1998)17:2<123::AIDZOO7>3.0.CO;2-B

Blackith, R. E. (1987). Primitive Orthoptera and primitive plants. In: B. Baccetti (Ed.), Evolutionary biology of Orthopteroid insects (pp. 124-126). Chichester, England: Ellis Horwood Limited.

Bloch, G., Hazan, E., \& Rafaeli, A. (2013). Circadian rhythms and endocrine functions in adult insects. Journal of Insect Physiology, 59, 56-69. doi: 10.1016/j.jinsphys.2012.10.012 
Brenes-Soto, A., \& Dierenfeld, E. S. (2014). Effect of dietary carotenoids on vitamin A status and skin pigmentation in false tomato frogs (Dyscophus guineti). Zoo Biology, 33, 544-552. https://doi.org/10.1002/zoo.21175

Browne, A., \& O’Donnell, M. J. (2018). Mechanisms of calcium sequestration by isolated Malpighian tubules of the house cricket Acheta domesticus. Archives of Insect Biochemistry and Physiology, 97, e21431. doi: 10.1002/arch.2143

Clifford, C., Roe, R. M., \& Woodring, J. P. (1977). Rearing methods for obtaining house crickets, Acheta domesticus, of known age, sex, and instar. Annals of the Entomological Society of America, 70, 69-74.

Clifford, C., \& Woodring, J. P. (1990). Methods for rearing the house cricket, Acheta domesticus (L.), along with baseline values for feeding rates, growth rates, development times, and blood composition. Journal of Applied Entomology, 109, 1-14.

Cohen, A. C. (2015). Insect diets: science and technology (2 $2^{\text {nd }}$ ed.). CRC Press.

Dadd, R. H. (1963). Feeding behavior and nutrition in grasshoppers and locusts. In: J. W. L. Beament, J. E. Treherne, \& V. B. Wigglesworth (Eds.) Advances in insect physiology (pp. 47-96). New York, NY: Academic Press.

Davidsson, L., Cederblad, A., Lonnerdal, B., \& Sandstrom, B. (1991). The effect of individual dietary components on manganese absorption in humans. American Journal of Clinical Nutrition, 54, 1065-1070.

Eitenmiller, R. R., \& Landen, W. O. (1999). Vitamin A and carotenoids. In: R. R. Eitenmiller \& W. O. Landen (Eds.), Vitamin analysis for the health and food sciences (pp. 3-66). CRC Press.

Ferrie, G. M., Alford, V. C., Atkinson, J., Baitchman, E., Barber, D., Blaner, W. S., ... Valdes, E. V. (2014). Nutrition and health in amphibian husbandry. Zoo Biology, 33, 485-501. http://doi.org/10.1002/zoo.21180

Finke, M. D. (2002). Complete nutrient composition of commercially raised invertebrates used as food for insectivores. Zoo Biology, 21, 269-285. http://doi.org/10.1002/zoo.10031 
Finke, M. D. (2003). Gut loading to enhance the nutrient content of insects as food for reptiles: a mathematical approach. Zoo Biology, 22, 147-162. http://doi.org/10.1002/zoo.10082

Finke, M. D., Dunham, S. U., \& Kwabi, C. A. (2005). Evaluation of four dry commercial gut loading products for improving the calcium content of crickets, Acheta domesticus. Journal of Herpetological Medicine and Surgery, 15, 7-12.

Finke, M. D., \& Oonincx, D. (2014). Insects as food for insectivores. In: J.A. Morales-Ramos, M. Guadalupe Rojas, \& D. I. Shapiro-Ilan (Eds.) Mass Production of Beneficial Organisms: Invertebrates and Entomopathogens (pp. 583-616). New York, NY: Academic Press. https://doi.org/10.1016/B978-0-12-391453-8.00017-0

Finke, M. D. (2015). Complete nutrient content of four species of commercially available feeder insects fed enhanced diets during growth. Zoo Biology, 34, 554-564. http://doi.org/10.1002/zoo.21246

Fowler, M. E. (1986). Metabolic bone disease. In: Fowler, M. E. (Ed.), Zoo and Wild Animal Medicine (2nd ed) (pp. 69-90). Philadelphia, PA: W. B. Saunders Co.

Hack, M. A. (1997). The effects of mass and age on standard metabolic rate in house crickets. Physiological Entomology, 22, 325-331. doi: 10.1111/j.1365-3032.1997.tb01176.x

Harrison, J. F., \& Fewell, J. H. (1995). Thermal effects of feeding behavior and net energy intake in a grasshopper experiencing large diurnal fluctuations in body temperature. Physiological Zoology, $68,453-473$.

Hoby, S., Wenker, C., Robert, N., Jermann, T., Hartnack, S., Segner, H., ... Liesegang, A. (2010). Nutritional metabolic bone disease in juvenile veiled chameleons (Chamaeleo calyptratus) and its prevention. The Journal of Nutrition, 140, 1923-1931. doi: 10.3945/jn.110.120998

Hunt Coslik, A., Ward, A. M., \& McClements, R. D. (2009). Gut loading as a method to effectively supplement crickets with calcium and vitamin A. Proceedings of the $8^{\text {th }}$ Conference on Zoo and Wildlife Nutrition (p. 163-171). Tulsa, OK: AZA Nutrition Advisory Group.

Kenchegowda, S. \& Bazan, H. E. P. (2010). Significance of lipid mediators in corneal injury and repair. Journal of Lipid Research, 51, 879-891. doi: 10.1194/jlr.R001347 
Klasing, K. C., Thacker, P., Lopez, M. A., \& Calvert, C. C. (2000). Increasing the calcium content of mealworms (Tenebrio molitor) to improve their nutritional value for bone mineralization of growing chicks. Journal of Zoo and Wildlife Medicine, 31, 512-517. http://doi.org/10.1638/10427260(2000)031

Klein, U. (1982). The articulation of cricket palps: morphology and movement patterns in behavior. Physiological Entomology, 7, 297-314.

Koutsos, E. A., Matson, K. D., \& Klasing, K. C. (2001). Nutrition of birds in the order Psittaciformes: a review. Journal of Avian Medicine and Surgery, 15, 257-275.

Li, H., Vaughan, M. J., \& Browne, R. K. (2009). A complex enrichment diet improves growth and health in the endangered Wyoming toad (Bufo baxteri). Zoo Biology, 28, 197-213. https://doi.org/10.1002/zoo.20223

Livingston, S., Lavin, S. R., Sullivan, K., Attard, L., \& Valdes, E. V. (2014). Challenges with effective nutrient supplementation for amphibians: a review of cricket studies. Zoo Biology, 33, 565-576. http://doi.org/10.1002/zoo.21177

Mazuri. 2016. Better Bug ${ }^{\circledR}$ gut loading diet (5B45). Retrieved from https://www.mazuri.com/product_pdfs/5B45.pdf

Mazuri. 2017. Cricket diet (5M7Q). Retrieved from https://www.mazuri.com/product_pdfs/5M7Q.pdf McComb, A. (2010). Evaluation of vitamin A supplementation for captive amphibian species. (Master's Thesis). North Carolina State University, Raleigh, NC, United States.

McGraw, K. J., Hill, G. E., Stradi, R., \& Parker, R. S. (2002). The effect of dietary carotenoid access on sexual dichromatism and plumage pigment composition in the American goldfinch. Comparative Biochemistry and Physiology - B Biochemistry and Molecular Biology, 131, 261-269. http://doi.org/10.1016/S1096-4959(01)00500-0

Michaels, C. J., Antwis, R. E. and Preziosi, R. F. (2014). Manipulation of the calcium content of insectivore diets through supplementary dusting. Journal of Zoo and Aquarium Research, 2, 7781. https://doi.org/10.19227/jzar.v2i3.59 
Michaels, C. J., Antwis, R. E. and Preziosi, R. F. (2015). Impacts of UVB provision and dietary calcium content on serum vitamin D3, growth rates, skeletal structure and coloration in captive oriental fire-bellied toads (Bombina orientalis). Journal of Animal Physiology and Animal Nutrition, 99, 391-403. doi:10.1111/jpn.12203

Newbrey, J. L., Paszkowski, C. A., \& Dumenko, E. D. (2013). A comparison of natural and restored wetlands as breeding bird habitat using a novel yolk carotenoid approach. Wetlands, 33, 471-482. http://doi.org/10.1007/s13157-013-0404-2

NFTA. (1993). Forage analyses procedures. Omaha, NE: National Forage Testing Association. Methods 2.2.2.2, 7

Nijboer, J. (n.d.) Nutrition in insectivores, edentates, and aardvarks. In: Merck Veterinary Manual. Retrieved from: https://www.merckvetmanual.com/management-and-nutrition/nutrition-exoticand-zoo-animals/nutrition-in-insectivores,-edentates,-and-aardvarks

Nijboer, J. (n.d.) Nutrition in reptiles. In: Merck Veterinary Manual. Retrieved from: https://www.merckvetmanual.com/management-and-nutrition/nutrition-exotic-and-zooanimals/nutrition-in-reptiles

NRC. (1980). Mineral tolerance of domestic animals. Washington, DC: National Academies Press.

NRC. (1982). United States—Canadian Tables of Feed Composition. Washington, DC: National Academies Press.

NRC. (1994). Nutrient requirements of poultry. Washington, DC: National Academies Press.

Odum, R.A., Bekker, K., Turski, P., Chastain, J., Paramuk, J., Pessier, A.P., ... Mendelson, J.R. (n.d.). Hypovitaminosis A: Are captive-bred insect prey deficient in usable vitamin A for Anaxyrus (Anura: Bufonidae)? Retrieved from: http://popfrog.org/Documents/VitaminAstudyabstract\%20final.pdf

Ogilvy, V., Fidgett, A. L., \& Preziosi R. F. (2012). Differences in carotenoid accumulation among three feeder-cricket species: implications for carotenoid delivery to captive insectivores. Zoo Biology, 32, 470-478. http://doi.org/10.1002/zoo.20416 
Pennino, M., Dierenfeld, E. S., \& Behler, J. L. (1991). Retinol, alpha-tocopherol and proximate nutrient composition of invertebrates used as feed. International Zoo Yearbook, 30, 143-149. https://doi.org/10.1111/j.1748-1090.1991.tb03477.x

Pessier A. (2007). Nutritional diseases of amphibians. Proceedings of the Seventh Conference on Zoo and Wildlife Nutrition, AZA Nutrition Advisory Group. Knoxville, TN.

Quadro, L., Hamberger, L., Colantuoni, V., Gottesman, M. E., \& Blaner, W. S. (2003). Understanding the physiological role of retinol-binding protein in vitamin A metabolism using transgenic and knockout mouse model. Molecular Aspects of Medicine, 24, 421-430. doi: 10.1016/S00982997(03)00038-

Restivo, T. (2018a). Microwave digestion of animal tissue (dry). In: CEM MARS 6 Microwave Acid Digestion Method Note Compendium. p 15. Retrieved from: http://cem.com/media/contenttype/media/literature/MetNote_MARS6_Compendium.pdf

Restivo, T. (2018b). Microwave digestion of food. In CEM MARS 6 Microwave Acid Digestion Method Note Compendium. p 76. Retrieved from: http://cem.com/media/contenttype/media/literature/MetNote_MARS6_Compendium.pdf

Rodríguez, C. E., \& Pessier, A. P. (2014). Pathologic changes associated with suspected hypovitaminosis A in amphibians under managed care. Zoo Biology, 33, 508-515. https://doi.org/10.1002/zoo.21161

Roe, R. M., Clifford, C. W., \& Woodring, J. P. (1980). The effect of temperature on feeding, growth, and metabolism during the last larval stadium of the female house cricket, Acheta domesticus. Journal of Insect Physiology, 26, $639-644$.

Sabatini, J. A., Dierenfeld, E. S., Fitzpatrick, M. P., Hashim, L. (1998). Effects of internal and external supplementation on the nutrient content of crickets. The Vivarium, 9, 23-24.

Shilton, C., Smith, D., Crawshaw, G., Valdes, E., Keller, C., Maguire, G., . . Atkinson, J. (2001). Corneal lipid deposition in Cuban tree frogs (Osteopilus septentrionalis) and its relationship to 
serum lipids: an experimental study. Journal of Zoo and Wildlife Medicine, 32, 305-319.

Retrieved from http://www.jstor.org.ezproxy.lib.calpoly.edu/stable/20096120

Strzelewicz, M. A., Ullrey, D. E., Schafer, S. F., \& Bacon, J. P. (1985). Increasing the calcium content of wax moth (Galleria mellonella). The Journal of Zoo Animal Medicine, 16, 25-27.

Sullivan, K. E., Lavin, S. R., Livingston, S. L., \& Valdes, E. V. (2012). Supplementation of crickets via a natural vitamin A source versus a synthetic source or beta carotene. Proceedings of the Comparative Nutrition Society Symposium 9th Bi-annual Conference. Asilomar, CA.

Taylor, C. W. 1986. Calcium regulation in insects. In: M. Adams, M. Chamberlin, J. A. T. Dow, J. Hanrahan, M. O’Shea, J. E. Phillips... B. Thomson (Eds.) Advances in insect physiology. Vol. 19 (pp. 155-186). New York, NY: Academic Press.

Trusk, A. M., Crissey, S. D. (1987). Comparison of calcium and phosphorus levels in crickets fed a high calcium diet versus those dusted with supplement. Proceedings of the 7th Annual Dr. Scholl Conference on the Nutrition of Captive Wild Animals (p. 93-99). Chicago, IL: Lincoln Park Zoological Gardens.

Underwood, E. J., \& Suttle, N. F. (1999). The mineral nutrition of livestock. $3^{\text {rd }}$ ed. New York, NY: CABI Publishing.

von Lintig, J. (2012). Metabolism of carotenoids and retinoids related to vision. Journal of Biological Chemistry, 287, 1627-1634. doi: 10.1074/jbc.R111.303990

Voolstra, O., Kiefer, C., Hoehne, M., Welsch, R., Vogt, K., \& von Lintig, J. (2006). The Drosophila class B scavenger receptor NinaD-I is a cell surface receptor mediating carotenoid transport for visual chromophore synthesis. Biochemistry, 45, 13429-13437.

Wetherbee, D. K. (1961). Investigations in the life history of the common Coturnix. The American Midland Naturalist Journal, 65, 168-186. doi: 10.1021/bi060701u

Woodring, J., Hoffmann, K. H., \& Lorenz, M. W. (2007). Activity, release and flow of digestive enzymes in the cricket, Gryllus bimaculatus. Physiological Entomology, 32, 56-63. http://doi.org/10.1111/j.1365-3032.2006.00541.x 
Woodring, J., \& Lorenz, M. W. (2007). Feeding, nutrient flow, and functional gut morphology in the cricket Gryllus bimaculatus. Journal of Morphology, 268, 254-274. http://doi.org/10.1002/jmor 
Table 1. Summary of references providing calcium, phosphorus, and calcium to phosphorus ratio values on listed insects. Corresponding age, sample size $(n)$, diet, time fed provided if information is available. All values expressed on a dry matter basis.

\begin{tabular}{|c|c|c|c|c|c|c|c|c|c|c|c|}
\hline Species & $\operatorname{Age}^{1}$ & $n$ & $\begin{array}{l}\text { Diet } \\
\text { Type }^{2}\end{array}$ & $\begin{array}{l}\text { Time } \\
\text { Fed }\end{array}$ & $\begin{array}{l}\text { Dietary } \\
\text { Ca, \% } \\
\pm \mathrm{SE}\end{array}$ & $\begin{array}{l}\text { Dietary } \\
\text { P, \% } \\
\pm \mathrm{SE}\end{array}$ & $\begin{array}{l}\text { Dietary } \\
\text { Ca:P, \% }\end{array}$ & $\begin{array}{l}\text { Insect } \\
\mathrm{Ca}, \% \\
\pm \mathrm{SE}^{4}\end{array}$ & $\begin{array}{l}\text { Insect } \\
\text { P, \% } \\
\pm \mathrm{SE}\end{array}$ & $\begin{array}{l}\text { Insect } \\
\mathrm{Ca}: P, \% \\
\pm \mathrm{SE}^{3,4}\end{array}$ & Reference \\
\hline \multirow[t]{14}{*}{ Acheta domesticus } & $\mathrm{A}$ & 12 & $\mathrm{~S}$ & $\begin{array}{l}48 \text { to } \\
120 \mathrm{~h}\end{array}$ & 2.92 & 0.76 & 3.84 & $\begin{array}{l}0.340 \pm \\
0.024\end{array}$ & $\begin{array}{l}0.859 \pm \\
0.019\end{array}$ & $\begin{array}{l}0.344 \pm \\
0.029\end{array}$ & $\begin{array}{l}\text { Allen \& Oftedal, } \\
1989\end{array}$ \\
\hline & A & 12 & $\mathrm{~S}$ & $\begin{array}{l}48 \text { to } \\
120 \mathrm{~h}\end{array}$ & 5.59 & 0.78 & 7.17 & $\begin{array}{l}0.539 \pm \\
0.039\end{array}$ & $\begin{array}{l}0.850 \pm \\
0.024\end{array}$ & $\begin{array}{l}0.649 \pm \\
0.059\end{array}$ & $\begin{array}{l}\text { Allen \& Oftedal, } \\
1989\end{array}$ \\
\hline & $\mathrm{A}$ & 12 & $\mathrm{~S}$ & $\begin{array}{l}48 \text { to } \\
120 \mathrm{~h}\end{array}$ & 7.69 & 0.70 & 10.99 & $\begin{array}{l}0.761 \pm \\
0.051\end{array}$ & $\begin{array}{l}0.853 \pm \\
0.022\end{array}$ & $\begin{array}{l}0.883 \pm \\
0.081\end{array}$ & $\begin{array}{l}\text { Allen \& Oftedal, } \\
1989\end{array}$ \\
\hline & A & 12 & $\mathrm{~S}$ & $\begin{array}{l}48 \text { to } \\
120 \mathrm{~h}\end{array}$ & 8.95 & 0.66 & 13.56 & $\begin{array}{l}1.044 \pm \\
0.100\end{array}$ & $\begin{array}{l}0.840 \pm \\
0.031\end{array}$ & $\begin{array}{l}1.296 \pm \\
0.153\end{array}$ & $\begin{array}{l}\text { Allen \& Oftedal, } \\
1989\end{array}$ \\
\hline & A & 12 & $\mathrm{~S}$ & $\begin{array}{l}48 \text { to } \\
120 \mathrm{~h}\end{array}$ & 10.57 & 0.72 & 14.68 & $\begin{array}{l}1.062 \pm \\
0.106\end{array}$ & $\begin{array}{l}0.852 \pm \\
0.035\end{array}$ & $\begin{array}{l}1.307 \pm \\
0.160\end{array}$ & $\begin{array}{l}\text { Allen \& Oftedal, } \\
1989\end{array}$ \\
\hline & A & 12 & S & $\begin{array}{l}48 \text { to } \\
120 \mathrm{~h}\end{array}$ & 11.44 & 0.70 & 16.34 & $\begin{array}{l}1.439 \pm \\
0.115\end{array}$ & $\begin{array}{l}0.865 \pm \\
0.031\end{array}$ & $\begin{array}{l}1.716 \pm \\
0.176\end{array}$ & $\begin{array}{l}\text { Allen \& Oftedal, } \\
1989\end{array}$ \\
\hline & $\mathrm{N}$ & 20 & NS & $0 \mathrm{~h}$ & 3.55 & 1.5 & 2.37 & $\begin{array}{l}0.257 \pm \\
0.021\end{array}$ & $\begin{array}{l}0.770 \pm \\
0.035\end{array}$ & $\begin{array}{l}0.330 \pm \\
0.027\end{array}$ & Anderson, 2000 \\
\hline & $\mathrm{N}$ & 20 & NS & $24 \mathrm{~h}$ & 3.55 & 1.5 & 2.37 & $\begin{array}{l}0.263 \pm \\
0.047\end{array}$ & $\begin{array}{l}0.790 \pm \\
0.027\end{array}$ & $\begin{array}{l}0.330 \pm \\
0.056\end{array}$ & Anderson, 2000 \\
\hline & $\mathrm{N}$ & 20 & NS & $48 \mathrm{~h}$ & 3.55 & 1.5 & 2.37 & $\begin{array}{l}0.250 \pm \\
0.050\end{array}$ & $\begin{array}{l}0.757 \pm \\
0.078\end{array}$ & $\begin{array}{l}0.330 \pm \\
0.036\end{array}$ & Anderson, 2000 \\
\hline & $\mathrm{N}$ & 20 & NS & $72 \mathrm{~h}$ & 3.55 & 1.5 & 2.37 & $\begin{array}{l}0.227 \pm \\
0.021\end{array}$ & $\begin{array}{l}0.770 \pm \\
0.027\end{array}$ & $\begin{array}{l}0.297 \pm \\
0.025\end{array}$ & Anderson, 2000 \\
\hline & $\mathrm{N}$ & 20 & $\mathrm{~S}$ & $24 \mathrm{~h}$ & 20.28 & 0.54 & 37.56 & $\begin{array}{l}0.257 \pm \\
0.035\end{array}$ & $\begin{array}{l}0.833 \pm \\
0.049\end{array}$ & $\begin{array}{l}0.310 \pm \\
0.044\end{array}$ & Anderson, 2000 \\
\hline & $\mathrm{N}$ & 20 & $\mathrm{~S}$ & $48 \mathrm{~h}$ & 20.28 & 0.54 & 37.56 & $\begin{array}{l}0.390 \pm \\
0.080\end{array}$ & $\begin{array}{l}0.850 \pm \\
0.030\end{array}$ & $\begin{array}{l}0.457 \pm \\
0.087\end{array}$ & Anderson, 2000 \\
\hline & $\mathrm{N}$ & 20 & S & $72 \mathrm{~h}$ & 20.28 & 0.54 & 37.56 & $\begin{array}{l}0.380 \pm \\
0.017\end{array}$ & $\begin{array}{l}0.887 \pm \\
0.021\end{array}$ & $\begin{array}{l}0.430 \pm \\
0.027\end{array}$ & Anderson, 2000 \\
\hline & $\mathrm{N}$ & 20 & $\mathrm{~S}$ & $24 \mathrm{~h}$ & 35.28 & 0.08 & 441.00 & $\begin{array}{l}0.337 \pm \\
0.055\end{array}$ & $\begin{array}{l}0.793 \pm \\
0.038\end{array}$ & $\begin{array}{l}0.423 \pm \\
0.061\end{array}$ & Anderson, 2000 \\
\hline
\end{tabular}




\begin{tabular}{|c|c|c|c|c|c|c|c|c|c|c|}
\hline $\mathrm{N}$ & 20 & $\mathrm{~S}$ & $48 \mathrm{~h}$ & 35.28 & 0.08 & 441.00 & $\begin{array}{l}0.453 \pm \\
0.059\end{array}$ & $\begin{array}{l}0.840 \pm \\
0.040\end{array}$ & $\begin{array}{l}0.540 \pm \\
0.070\end{array}$ & Anderson, 2000 \\
\hline $\mathrm{N}$ & 20 & $\mathrm{~S}$ & $72 \mathrm{~h}$ & 35.28 & 0.08 & 441.00 & $\begin{array}{l}0.577 \pm \\
0.107\end{array}$ & $\begin{array}{l}0.880 \pm \\
0.021\end{array}$ & $\begin{array}{l}0.430 \pm \\
0.027\end{array}$ & Anderson, 2000 \\
\hline $\mathrm{N}$ & 20 & $\mathrm{~S}$ & $24 \mathrm{~h}$ & 12.14 & 0.80 & 15.18 & $\begin{array}{l}0.843 \pm \\
0.067\end{array}$ & $\begin{array}{l}0.760 \pm \\
0.020\end{array}$ & $\begin{array}{l}1.107 \pm \\
0.070\end{array}$ & Anderson, 2000 \\
\hline $\mathrm{N}$ & 20 & $\mathrm{~S}$ & $48 \mathrm{~h}$ & 12.14 & 0.80 & 15.18 & $\begin{array}{l}0.810 \pm \\
0.053\end{array}$ & $\begin{array}{l}0.777 \\
\pm 0.006\end{array}$ & $\begin{array}{l}1.040 \pm \\
0.072\end{array}$ & Anderson, 2000 \\
\hline $\mathrm{N}$ & 20 & $\mathrm{~S}$ & $72 \mathrm{~h}$ & 12.14 & 0.80 & 15.18 & $\begin{array}{l}0.807 \pm \\
0.076\end{array}$ & $\begin{array}{l}0.810 \pm \\
0.052\end{array}$ & $\begin{array}{l}1.001 \pm \\
0.150\end{array}$ & Anderson, 2000 \\
\hline $\mathrm{N}$ & 20 & $\mathrm{~S}$ & $24 \mathrm{~h}$ & 7.15 & 0.91 & 7.86 & $\begin{array}{l}0.915 \pm \\
0.120\end{array}$ & $\begin{array}{l}0.830 \pm \\
0.053\end{array}$ & $\begin{array}{l}1.140 \pm \\
0.127\end{array}$ & Anderson, 2000 \\
\hline $\mathrm{N}$ & 20 & $\mathrm{~S}$ & $48 \mathrm{~h}$ & 7.15 & 0.91 & 7.86 & $\begin{array}{l}0.815 \pm \\
0.106 \%\end{array}$ & $\begin{array}{l}0.823 \pm \\
0.006 \%\end{array}$ & $\begin{array}{l}0.990 \pm \\
0.141 \%\end{array}$ & Anderson, 2000 \\
\hline $\mathrm{N}$ & 20 & $\mathrm{~S}$ & $72 \mathrm{~h}$ & 7.15 & 0.91 & 7.86 & $\begin{array}{l}0.673 \pm \\
0.032\end{array}$ & $\begin{array}{l}0.813 \pm \\
0.015\end{array}$ & $\begin{array}{l}0.830 \pm \\
0.050\end{array}$ & Anderson, 2000 \\
\hline $\mathrm{N}$ & - & NS & - & 0.09 & 1.06 & 0.08 & 0.11 & 0.84 & 0.13 & Arbuckle, 2009 \\
\hline $\mathrm{N}$ & - & $\mathrm{S}$ & - & 4.84 & 1.01 & 4.79 & 0.36 & 0.89 & 0.40 & Arbuckle, 2009 \\
\hline $\mathrm{A}$ & 6 & NS & - & - & - & - & $\begin{array}{l}0.21 \pm \\
0.03\end{array}$ & $\begin{array}{l}0.78 \pm \\
0.08\end{array}$ & 0.26 & Barker et al., 1998 \\
\hline $\mathrm{N}$ & 8 & NS & - & - & - & - & $\begin{array}{l}1.29 \pm \\
2.26\end{array}$ & $\begin{array}{l}0.79 \pm \\
0.19\end{array}$ & 1.63 & Barker et al., 1998 \\
\hline $\mathrm{N}$ & $\begin{array}{l}13- \\
17\end{array}$ & NS & $48 \mathrm{~h}$ & $\begin{array}{l}1.00 \pm \\
0.02\end{array}$ & $\begin{array}{l}0.67 \pm \\
0.02\end{array}$ & 1.64 & $\begin{array}{l}1.10 \pm \\
0.08\end{array}$ & $\begin{array}{l}0.98 \pm \\
0.08\end{array}$ & 1.21 & Finke, 2005 \\
\hline $\mathrm{A}$ & $\begin{array}{l}9- \\
12\end{array}$ & NS & $48 \mathrm{~h}$ & $\begin{array}{l}1.00 \pm \\
0.02\end{array}$ & $\begin{array}{l}0.67 \pm \\
0.02\end{array}$ & 1.64 & $\begin{array}{l}0.63 \pm \\
0.07\end{array}$ & $\begin{array}{l}0.84 \pm \\
0.04\end{array}$ & 0.75 & Finke, 2005 \\
\hline $\mathrm{N}$ & $\begin{array}{l}13- \\
17\end{array}$ & $\mathrm{~S}$ & $48 \mathrm{~h}$ & $\begin{array}{l}6.54 \pm \\
0.20\end{array}$ & $\begin{array}{l}0.72 \pm \\
0.03\end{array}$ & 9.08 & $\begin{array}{l}0.21 \pm \\
0.0\end{array}$ & $0.97 \pm 0.0$ & 0.21 & Finke, 2005 \\
\hline $\mathrm{A}$ & $\begin{array}{l}9- \\
12\end{array}$ & $\mathrm{~S}$ & $48 \mathrm{~h}$ & $\begin{array}{l}6.54 \pm \\
0.20\end{array}$ & $\begin{array}{l}0.72 \pm \\
0.03\end{array}$ & 9.08 & $\begin{array}{l}0.17 \pm \\
0.01\end{array}$ & $\begin{array}{l}0.85 \pm \\
0.01\end{array}$ & 0.20 & Finke, 2005 \\
\hline $\mathrm{N}$ & $\begin{array}{l}13- \\
17\end{array}$ & $\mathrm{~S}$ & $48 \mathrm{~h}$ & $\begin{array}{l}1.09 \pm \\
0.03\end{array}$ & $\begin{array}{l}0.72 \pm \\
0.02\end{array}$ & 1.51 & $\begin{array}{l}0.29 \pm \\
0.02\end{array}$ & $\begin{array}{l}1.07 \pm \\
0.02\end{array}$ & 0.27 & Finke, 2005 \\
\hline A & $\begin{array}{l}9- \\
12\end{array}$ & $\mathrm{~S}$ & $48 \mathrm{~h}$ & $\begin{array}{l}1.09 \pm \\
0.03\end{array}$ & $\begin{array}{l}0.72 \pm \\
0.02\end{array}$ & 1.51 & $\begin{array}{l}0.19 \pm \\
0.01\end{array}$ & $\begin{array}{l}0.83 \pm \\
0.01\end{array}$ & 0.23 & Finke, 2005 \\
\hline
\end{tabular}




\begin{tabular}{|c|c|c|c|c|c|c|c|c|c|c|c|}
\hline & $\mathrm{N}$ & $\begin{array}{l}13- \\
17\end{array}$ & $S$ & $48 \mathrm{~h}$ & $\begin{array}{l}1.32 \pm \\
0.08\end{array}$ & $\begin{array}{l}0.53 \pm \\
0.02\end{array}$ & 2.49 & $\begin{array}{l}0.41 \pm \\
0.01\end{array}$ & $\begin{array}{l}1.05 \pm \\
0.01\end{array}$ & 0.39 & Finke, 2005 \\
\hline & A & $\begin{array}{l}9- \\
12\end{array}$ & $S$ & $48 \mathrm{~h}$ & $\begin{array}{l}1.32 \pm \\
0.08\end{array}$ & $\begin{array}{l}0.53 \pm \\
0.02\end{array}$ & 2.49 & $\begin{array}{l}0.18 \pm \\
0.0\end{array}$ & $\begin{array}{l}0.91 \pm \\
0.01\end{array}$ & 0.20 & Finke, 2005 \\
\hline & $\mathrm{N}$ & $\begin{array}{l}13- \\
17\end{array}$ & $\mathrm{~S}$ & $48 \mathrm{~h}$ & $\begin{array}{l}1.71 \pm \\
0.02\end{array}$ & $\begin{array}{l}1.16 \pm \\
0.03\end{array}$ & 1.47 & $\begin{array}{l}0.37 \pm \\
0.06\end{array}$ & $\begin{array}{l}1.00 \pm \\
0.06\end{array}$ & 0.37 & Finke, 2005 \\
\hline & A & $\begin{array}{l}9- \\
12\end{array}$ & $\mathrm{~S}$ & $48 \mathrm{~h}$ & $\begin{array}{l}1.71 \pm \\
0.02\end{array}$ & $\begin{array}{l}1.16 \pm \\
0.03\end{array}$ & 1.47 & $\begin{array}{l}0.29 \pm \\
0.01\end{array}$ & $\begin{array}{l}0.86 \pm \\
0.01\end{array}$ & 0.34 & Finke, 2005 \\
\hline & $\mathrm{N}$ & $\begin{array}{l}13- \\
17\end{array}$ & $\mathrm{~S}$ & $48 \mathrm{~h}$ & $\begin{array}{l}10.34 \pm \\
0.03\end{array}$ & $\begin{array}{l}0.77 \pm \\
0.02\end{array}$ & 13.43 & $\begin{array}{l}1.19 \pm \\
0.07\end{array}$ & $\begin{array}{l}0.94 \pm \\
0.07\end{array}$ & 1.26 & Finke, 2005 \\
\hline & $\mathrm{A}$ & $\begin{array}{l}9- \\
12\end{array}$ & $S$ & $48 \mathrm{~h}$ & $\begin{array}{l}10.34 \pm \\
0.03\end{array}$ & $\begin{array}{l}0.77 \pm \\
0.02\end{array}$ & 13.43 & $\begin{array}{l}0.82 \pm \\
0.10\end{array}$ & $0.92 \pm 0.0$ & 0.89 & Finke, 2005 \\
\hline & $\mathrm{N}$ & - & $\mathrm{F}$ & $-24 \mathrm{~h}$ & - & - & - & 0.13 & 0.80 & 0.16 & Finke, 2015 \\
\hline Brachytrupes spp. & $\mathrm{A}$ & - & $\mathrm{W}$ & - & - & - & - & 0.0095 & 0.1314 & 0.0723 & Banjo et al., 2006 \\
\hline $\begin{array}{l}\text { Drosophila } \\
\text { melanogaster }\end{array}$ & - & 4 & NS & - & - & - & - & $\begin{array}{l}0.14 \pm \\
0.22\end{array}$ & $\begin{array}{l}1.10 \pm \\
0.05\end{array}$ & 0.13 & Barker et al., 1998 \\
\hline \multirow[t]{6}{*}{$\begin{array}{l}\text { Galleria } \\
\text { mellonella }\end{array}$} & $\mathrm{L}$ & 5 & NS & - & - & - & - & $\begin{array}{l}0.06 \pm \\
0.01\end{array}$ & $\begin{array}{l}1.20 \pm \\
0.11\end{array}$ & 0.05 & Barker et al., 1998 \\
\hline & $\mathrm{L}$ & - & $\mathrm{F}$ & $-24 \mathrm{~h}$ & - & - & - & 0.06 & 0.54 & 0.11 & Finke, 2015 \\
\hline & $\mathrm{L}$ & 25 & $\mathrm{~S}$ & $48 \mathrm{~h}$ & 5.7 & 0.33 & 17.2 & 0.21 & 0.20 & 1.05 & $\begin{array}{l}\text { Strzelewicz et al, } \\
1985\end{array}$ \\
\hline & $\mathrm{L}$ & 25 & $S$ & $72 \mathrm{~h}$ & 5.7 & 0.33 & 17.2 & 0.31 & 0.24 & 1.29 & $\begin{array}{l}\text { Strzelewicz et al, } \\
1985\end{array}$ \\
\hline & $\mathrm{L}$ & 25 & S & $48 \mathrm{~h}$ & 7.9 & 0.30 & 26.3 & 0.24 & 0.26 & 0.92 & $\begin{array}{l}\text { Strzelewicz et al, } \\
1985\end{array}$ \\
\hline & $\mathrm{L}$ & 25 & $S$ & $72 \mathrm{~h}$ & 7.9 & 0.30 & 26.3 & 0.28 & 0.21 & 1.33 & $\begin{array}{l}\text { Strzelewicz et al, } \\
1985\end{array}$ \\
\hline \multirow{2}{*}{$\begin{array}{l}\text { Gryllodes } \\
\text { sigillatus }\end{array}$} & $\mathrm{N}$ & - & NS & - & 0.09 & 1.06 & 0.08 & 0.11 & 0.87 & 0.13 & Arbuckle, 2009 \\
\hline & $\mathrm{N}$ & - & S & - & 4.84 & 1.01 & 4.79 & 0.22 & 0.92 & 0.24 & Arbuckle, 2009 \\
\hline \multirow{2}{*}{$\begin{array}{l}\text { Gryllus } \\
\text { bimaculatus }\end{array}$} & $\mathrm{N}$ & - & NS & - & 0.09 & 1.06 & 0.08 & 0.09 & 0.93 & 0.10 & Arbuckle, 2009 \\
\hline & $\mathrm{N}$ & - & $\mathrm{S}$ & - & 4.84 & 1.01 & 4.79 & 0.34 & 0.91 & 0.37 & Arbuckle, 2009 \\
\hline
\end{tabular}




\begin{tabular}{|c|c|c|c|c|c|c|c|c|c|c|c|}
\hline \multirow[t]{2}{*}{$\begin{array}{l}\text { Lumbricus } \\
\text { terrestris }\end{array}$} & - & 6 & $\mathrm{~W}$ & - & - & - & - & $\begin{array}{l}0.97 \pm \\
0.28\end{array}$ & $\begin{array}{l}0.79 \pm \\
0.13\end{array}$ & 3.46 & Barker et al., 1998 \\
\hline & - & 6 & NS & - & - & - & - & $\begin{array}{l}1.21 \pm \\
0.03\end{array}$ & $\begin{array}{l}0.86 \pm \\
0.15\end{array}$ & 1.41 & Barker et al., 1998 \\
\hline \multirow[t]{16}{*}{ Tenebrio molitor } & $\mathrm{L}$ & 20 & $\mathrm{NS}$ & $0 \mathrm{~h}$ & 1.40 & 1.50 & 0.93 & $\begin{array}{l}0.170 \pm \\
0.040\end{array}$ & $\begin{array}{l}0.763 \pm \\
0.057\end{array}$ & $\begin{array}{l}0.223 \pm \\
0.047\end{array}$ & Anderson, 2000 \\
\hline & $\mathrm{L}$ & 20 & NS & $24 \mathrm{~h}$ & 1.40 & 1.50 & 0.93 & $\begin{array}{l}0.147 \pm \\
0.040\end{array}$ & $\begin{array}{l}0.747 \pm \\
0.047\end{array}$ & $\begin{array}{l}0.200 \pm \\
0.061\end{array}$ & Anderson, 2000 \\
\hline & $\mathrm{L}$ & 20 & $\mathrm{NS}$ & $48 \mathrm{~h}$ & 1.40 & 1.50 & 0.93 & $\begin{array}{l}0.163 \pm \\
0.076\end{array}$ & $\begin{array}{l}0.747 \pm \\
0.029\end{array}$ & $\begin{array}{l}0.220 \pm \\
0.104\end{array}$ & Anderson, 2000 \\
\hline & $\mathrm{L}$ & 20 & NS & $72 \mathrm{~h}$ & 1.40 & 1.50 & 0.93 & $\begin{array}{l}0.167 \pm \\
0.055\end{array}$ & $\begin{array}{l}0.723 \pm \\
0.078\end{array}$ & $\begin{array}{l}0.227 \pm \\
0.047\end{array}$ & Anderson, 2000 \\
\hline & $\mathrm{L}$ & 20 & $\mathrm{~S}$ & $24 \mathrm{~h}$ & 20.28 & 0.54 & 37.56 & $\begin{array}{l}0.383 \pm \\
0.050\end{array}$ & $\begin{array}{l}0.720 \pm \\
0.089\end{array}$ & $\begin{array}{l}0.530 \pm \\
0.010\end{array}$ & Anderson, 2000 \\
\hline & $\mathrm{L}$ & 20 & $\mathrm{~S}$ & $48 \mathrm{~h}$ & 20.28 & 0.54 & 37.56 & $\begin{array}{l}0.480 \pm \\
0.036\end{array}$ & $\begin{array}{l}0.727 \pm \\
0.032\end{array}$ & $\begin{array}{l}0.660 \pm \\
0.027\end{array}$ & Anderson, 2000 \\
\hline & $\mathrm{L}$ & 20 & $\mathrm{~S}$ & $72 \mathrm{~h}$ & 20.28 & 0.54 & 37.56 & $\begin{array}{l}0.573 \pm \\
0.074\end{array}$ & $\begin{array}{l}0.747 \pm \\
0.040\end{array}$ & $\begin{array}{l}0.767 \pm \\
0.067\end{array}$ & Anderson, 2000 \\
\hline & $\mathrm{L}$ & 20 & $\mathrm{~S}$ & $24 \mathrm{~h}$ & 35.28 & 0.08 & 441.00 & $\begin{array}{l}0.837 \pm \\
0.078\end{array}$ & $\begin{array}{l}0.777 \pm \\
0.031\end{array}$ & $\begin{array}{l}1.077 \pm \\
0.095\end{array}$ & Anderson, 2000 \\
\hline & $\mathrm{L}$ & 20 & $\mathrm{~S}$ & $48 \mathrm{~h}$ & 35.28 & 0.08 & 441.00 & $\begin{array}{l}0.893 \pm \\
0.199\end{array}$ & $\begin{array}{l}0.720 \pm \\
0.027\end{array}$ & $\begin{array}{l}1.240 \pm \\
0.154\end{array}$ & Anderson, 2000 \\
\hline & $\mathrm{L}$ & 20 & $\mathrm{~S}$ & $72 \mathrm{~h}$ & 35.28 & 0.08 & 441.00 & $\begin{array}{l}1.047 \pm \\
0.078\end{array}$ & $\begin{array}{l}0.743 \pm \\
0.015\end{array}$ & $\begin{array}{l}1.410 \pm \\
0.135\end{array}$ & Anderson, 2000 \\
\hline & $\mathrm{L}$ & 20 & $\mathrm{~S}$ & $24 \mathrm{~h}$ & 8.13 & 0.93 & 8.74 & $\begin{array}{l}0.557 \pm \\
0.081\end{array}$ & $\begin{array}{l}0.773 \pm \\
0.023\end{array}$ & $\begin{array}{l}0.723 \pm \\
0.119\end{array}$ & Anderson, 2000 \\
\hline & $\mathrm{L}$ & 20 & $\mathrm{~S}$ & $48 \mathrm{~h}$ & 8.13 & 0.93 & 8.74 & $\begin{array}{l}0.520 \pm \\
0.020\end{array}$ & $\begin{array}{l}0.767 \pm \\
0.025\end{array}$ & $\begin{array}{l}0.567 \pm \\
0.110\end{array}$ & Anderson, 2000 \\
\hline & $\mathrm{L}$ & 20 & $\mathrm{~S}$ & $72 \mathrm{~h}$ & 8.13 & 0.93 & 8.74 & $\begin{array}{l}0.560 \pm \\
0.056\end{array}$ & $\begin{array}{l}0.780 \pm \\
0.020\end{array}$ & $\begin{array}{l}0.723 \pm \\
0.091\end{array}$ & Anderson, 2000 \\
\hline & $\mathrm{L}$ & 20 & $\mathrm{~S}$ & $24 \mathrm{~h}$ & 7.15 & 0.91 & 7.86 & $\begin{array}{l}0.373 \pm \\
0.029\end{array}$ & $\begin{array}{l}0.760 \pm \\
0.010\end{array}$ & $\begin{array}{l}0.490 \pm \\
0.044\end{array}$ & Anderson, 2000 \\
\hline & $\mathrm{L}$ & 20 & $\mathrm{~S}$ & $48 \mathrm{~h}$ & 7.15 & 0.91 & 7.86 & $\begin{array}{l}0.433 \pm \\
0.081\end{array}$ & $\begin{array}{l}0.767 \pm \\
0.025\end{array}$ & $\begin{array}{l}0.567 \pm \\
0.110\end{array}$ & Anderson, 2000 \\
\hline & $\mathrm{L}$ & 20 & $\mathrm{~S}$ & $72 \mathrm{~h}$ & 7.15 & 0.91 & 7.86 & $\begin{array}{l}0.503 \pm \\
0.047\end{array}$ & $\begin{array}{l}0.763 \pm \\
0.021\end{array}$ & $\begin{array}{l}0.660 \pm \\
0.044\end{array}$ & Anderson, 2000 \\
\hline
\end{tabular}




\begin{tabular}{|c|c|c|c|c|c|c|c|c|c|c|c|}
\hline & $\mathrm{L}$ & 6 & NS & - & - & - & - & $\begin{array}{l}0.12 \pm \\
0.09\end{array}$ & $\begin{array}{l}1.42 \pm \\
0.15\end{array}$ & 0.08 & Barker et al., 1998 \\
\hline & $\mathrm{L}$ & 6 & NS & - & - & - & - & $\begin{array}{l}0.03 \pm \\
0.01\end{array}$ & $\begin{array}{l}1.27 \pm \\
0.28\end{array}$ & 0.02 & Barker et al., 1998 \\
\hline & $\mathrm{L}$ & - & $\mathrm{F}$ & $-24 h$ & - & - & - & 0.05 & 0.85 & 0.06 & Finke, 2015 \\
\hline \multirow[t]{2}{*}{ Zophobas morio } & $\mathrm{L}$ & 6 & NS & - & - & - & - & $\begin{array}{l}0.12 \pm \\
0.15\end{array}$ & $\begin{array}{l}0.83 \pm \\
0.24\end{array}$ & 0.14 & Barker et al., 1998 \\
\hline & $\mathrm{L}$ & - & $\mathrm{F}$ & $-24 h$ & - & - & - & 0.07 & 0.56 & 0.13 & Finke, 2015 \\
\hline
\end{tabular}

${ }^{1} \mathrm{~A}=$ adult $; \mathrm{N}=$ nymph; $\mathrm{L}=$ larvae

${ }^{2} \mathrm{~W}=$ wild caught insects; NS = not supplemented $\mathrm{S}=$ supplemented $; \mathrm{F}=$ fasted

${ }^{3}$ Calculated as calcium $\% \div$ phosphorus $\%$.

${ }^{4}$ Target insect $\mathrm{Ca}$ values to meet insectivore requirements may range from 0.80 to $2.5 \%$ with a corresponding insect 1:1 Ca:P ratio (Table 3; Nijboer, n.d.; NRC, 1994). 
Table 2. Summary of references providing vitamin A and beta-carotene values on listed insects. Corresponding age, sample size (n), diet, time fed provided if information is available. All values expressed on a dry matter basis, unless otherwise indicated.

\begin{tabular}{|c|c|c|c|c|c|c|c|c|c|}
\hline Species & Age $^{1}$ & $n$ & $\begin{array}{l}\text { Diet } \\
\text { Type }^{2}\end{array}$ & $\begin{array}{l}\text { Time } \\
\text { Fed }\end{array}$ & $\begin{array}{l}\text { Dietary } \\
\text { Vitamin A, } \\
\text { IU/kg }\end{array}$ & $\begin{array}{l}\text { Dietary } \\
\beta \text {-carotene, } \\
\mu \mathrm{g} / \mathrm{g}\end{array}$ & $\begin{array}{l}\text { Insect } \\
\text { Vitamin } A, \\
\text { IU/kg } \pm S^{3}\end{array}$ & $\begin{array}{l}\text { Insect } \\
\beta \text {-carotene, } \\
\mu \mathrm{g} / \mathrm{g} \pm \mathrm{SE}^{4}\end{array}$ & Reference \\
\hline \multirow[t]{24}{*}{ Acheta domesticus } & $\mathrm{A}$ & 6 & NS & - & - & - & $811 \pm 849$ & - & Barker et al., 1998 \\
\hline & $\mathrm{N}$ & 8 & NS & - & - & - & $471 \pm 585$ & - & Barker et al., 1998 \\
\hline & A & - & $\mathrm{S}$ & $48 \mathrm{~h}$ & 5,674 & - & 291 & - & Finke, 2003 \\
\hline & A & - & $\mathrm{S}$ & $48 \mathrm{~h}$ & 15,946 & - & 690 & - & Finke, 2003 \\
\hline & A & - & $S$ & $48 \mathrm{~h}$ & 20,788 & - & 945 & - & Finke, 2003 \\
\hline & A & - & $S$ & $48 \mathrm{~h}$ & 26,244 & - & 1,470 & - & Finke, 2003 \\
\hline & A & - & $\mathrm{S}$ & $48 \mathrm{~h}$ & 32,894 & - & 1,755 & - & Finke, 2003 \\
\hline & $\mathrm{N}$ & - & $\mathrm{S}$ & $48 \mathrm{~h}$ & 5,674 & - & 390 & - & Finke, 2003 \\
\hline & $\mathrm{N}$ & - & $S$ & $48 \mathrm{~h}$ & 11,484 & - & 870 & - & Finke, 2003 \\
\hline & $\mathrm{N}$ & - & $S$ & $48 \mathrm{~h}$ & 15,946 & - & 957 & - & Finke, 2003 \\
\hline & $\mathrm{N}$ & - & $\mathrm{S}$ & $48 \mathrm{~h}$ & 20,788 & - & 1,455 & - & Finke, 2003 \\
\hline & $\mathrm{N}$ & - & $\mathrm{S}$ & $48 \mathrm{~h}$ & 26,244 & - & 1,755 & - & Finke, 2003 \\
\hline & $\mathrm{N}$ & - & $\mathrm{S}$ & $48 \mathrm{~h}$ & 32,894 & - & 2,520 & - & Finke, 2003 \\
\hline & - & - & NS & $72 \mathrm{~h}$ & - & - & 628 & - & McComb, 2010 \\
\hline & - & - & $\mathrm{S}$ & $72 \mathrm{~h}$ & - & - & 43,715 & - & McComb, 2010 \\
\hline & A & 28 & NS & $\mathrm{INJ}^{5}$ & $\leq 1,000$ & - & $333.3 \pm 30.0$ & $0.14 \pm 0.03$ & $\begin{array}{l}\text { Brenes-Soto \& } \\
\text { Dierenfeld, 2014 }\end{array}$ \\
\hline & A & 28 & $S$ & $\mathrm{INJ}^{5}$ & 2,000 & - & $\begin{array}{l}566.7 \pm \\
200.0\end{array}$ & $\begin{array}{l}306.39 \pm \\
0.24\end{array}$ & $\begin{array}{l}\text { Brenes-Soto \& } \\
\text { Dierenfeld, 2014 }\end{array}$ \\
\hline & A & 28 & $S$ & $\mathrm{INJ}^{5}$ & 7,400 & - & $1,100 \pm 66.7$ & $363.55 \pm 1.12$ & $\begin{array}{l}\text { Brenes-Soto \& } \\
\text { Dierenfeld, 2014 }\end{array}$ \\
\hline & $\mathrm{N}$ & 46 & NS & $\mathrm{INJ}^{5}$ & $\leq 1,000$ & - & $266.7 \pm 16.7$ & $0.00 \pm 0.00$ & $\begin{array}{l}\text { Brenes-Soto \& } \\
\text { Dierenfeld, 2014 }\end{array}$ \\
\hline & $\mathrm{N}$ & 46 & $S$ & $\mathrm{INJ}^{5}$ & 2,000 & - & $\begin{array}{l}666.7 \pm \\
133.3\end{array}$ & $\begin{array}{l}471.73 \pm \\
0.001\end{array}$ & $\begin{array}{l}\text { Brenes-Soto \& } \\
\text { Dierenfeld, 2014 }\end{array}$ \\
\hline & $\mathrm{N}$ & 46 & $S$ & $\mathrm{INJ}^{5}$ & 7,400 & - & $\begin{array}{l}3,333 \pm \\
533.3\end{array}$ & $\begin{array}{l}268.53 \pm \\
4.53\end{array}$ & $\begin{array}{l}\text { Brenes-Soto \& } \\
\text { Dierenfeld, 2014 }\end{array}$ \\
\hline & $\mathrm{N}$ & 15 & NS & $6 \mathrm{~d}$ & - & - & - & $3.06 \pm 3.87$ & Ogilvy et al., 2012 \\
\hline & $\mathrm{N}$ & 15 & $\mathrm{~S}$ & $6 \mathrm{~d}$ & - & - & - & $16.66 \pm 6.01$ & Ogilvy et al., 2012 \\
\hline & - & 2 & NS & - & - & - & 100 & - & Pennino et al., $1991^{7}$ \\
\hline
\end{tabular}




\begin{tabular}{|c|c|c|c|c|c|c|c|c|c|}
\hline Apis mellifera $(\overbrace{}^{\Uparrow})$ & - & 1 & NS & - & - & - & 3,100 & - & Pennino et al., $1991^{7}$ \\
\hline Apis mellifera $(q)$ & - & 1 & NS & - & - & - & $2,833.3$ & - & Pennino et al., $1991^{7}$ \\
\hline Blatella germanica & - & 2 & $\mathrm{~W}$ & - & - & - & $3,666.7$ & - & Pennino et al., $1991^{7}$ \\
\hline \multirow[t]{2}{*}{ Galleria mellonella } & $\mathrm{L}$ & 6 & NS & - & - & - & $150 \pm 160$ & - & Barker et al., 1998 \\
\hline & $\mathrm{L}$ & 2 & NS & - & - & - & $1,166.7$ & - & Pennino et al., $1991^{7}$ \\
\hline \multirow[t]{2}{*}{ Gryllodes sigillatus } & $\mathrm{N}$ & 15 & NS & $6 \mathrm{~d}$ & - & - & - & $0.91 \pm 1.58$ & Ogilvy et al., 2012 \\
\hline & $\mathrm{N}$ & 15 & $\mathrm{~S}$ & $6 \mathrm{~d}$ & - & - & - & $12.63 \pm 8.17$ & Ogilvy et al., 2012 \\
\hline \multirow[t]{2}{*}{ Gryllus bimaculatus } & $\mathrm{N}$ & 15 & NS & $6 \mathrm{~d}$ & - & - & - & $0.61 \pm 0.56$ & Ogilvy et al., 2012 \\
\hline & $\mathrm{N}$ & 15 & $\mathrm{~S}$ & $6 \mathrm{~d}$ & - & - & - & $28.71 \pm 8.7$ & Ogilvy et al., 2012 \\
\hline \multirow[t]{3}{*}{ Lumbricus terrestris } & - & 6 & $\mathrm{~W}$ & - & - & - & $2400 \pm 279$ & - & Barker et al., 1998 \\
\hline & - & 6 & NS & - & - & - & $328 \pm 171$ & - & Barker et al., 1998 \\
\hline & - & 1 & NS & - & - & - & 6,000 & - & Pennino et al., $1991^{7}$ \\
\hline \multirow[t]{8}{*}{ Tenebrio molitar } & $\mathrm{L}$ & 6 & NS & - & - & - & $811 \pm 324$ & - & Barker et al., 1998 \\
\hline & $\mathrm{L}$ & 6 & NS & - & - & - & $161 \pm 91$ & - & Barker et al., 1998 \\
\hline & $\mathrm{L}$ & - & $\mathrm{S}$ & $48 \mathrm{~h}$ & 5,650 & - & 234 & - & Finke, 2003 \\
\hline & $\mathrm{L}$ & - & $\mathrm{S}$ & $48 \mathrm{~h}$ & 11,695 & - & 450 & - & Finke, 2003 \\
\hline & $\mathrm{L}$ & - & $\mathrm{S}$ & $48 \mathrm{~h}$ & 18,854 & - & 720 & - & Finke, 2003 \\
\hline & $\mathrm{L}$ & - & $\mathrm{S}$ & $48 \mathrm{~h}$ & 25,784 & - & 870 & - & Finke, 2003 \\
\hline & $\mathrm{L}$ & 3 & NS & - & - & - & 133.3 & - & Pennino et al., $1991^{7}$ \\
\hline & $\mathrm{L}$ & 1 & $\mathrm{NS}$ & - & - & - & 666.7 & - & Pennino et al., $1991^{7}$ \\
\hline Zophobas morio & $\mathrm{L}$ & 6 & $\mathrm{NS}$ & - & - & - & $972 \pm 570$ & - & Barker et al., 1998 \\
\hline
\end{tabular}

${ }^{1} \mathrm{~A}=$ adult; $\mathrm{N}=$ nymph; $\mathrm{L}=$ larvae

${ }^{2} \mathrm{~W}=$ wild caught insects; $\mathrm{NS}=$ Not supplemented; $\mathrm{S}=$ supplemented

${ }^{3} \mathrm{~A}$ target insect vitamin A concentration is listed as 5,000 to 10,000 IU/kg for carnivorous reptiles, 15,000 IU/kg for omnivorous reptiles, 1,650 IU/kg for starting/growing insectivorous bird (Coturnix japonica), and 3,300 IU/kg for a breeding insectivorous bird (C. japonica) (Nijboer, n.d.; NRC 1994).

${ }^{4}$ Beta-carotene concentration divided by 0.6 will convert the concentration to vitamin A IU/g (NRC, 1982).

${ }^{5} \mathrm{INJ}=$ Injected with supplement

${ }^{6}$ As-is basis. 
${ }^{7}$ Vitamin A on a $\mu \mathrm{g} / \mathrm{g}$ basis converted to IU/kg with the following calculation:

$[(\mu \mathrm{g} / \mathrm{g} * 1000) \div 0.300 \mu \mathrm{g} / \mathrm{IU}$ vitamin $\mathrm{A}]$

where 0.300 is used to convert $\mu \mathrm{g}$ to IU vitamin A as retinol (NRC, 1982). 
Table 3. Reference dry matter, ash, macro and trace mineral content of non-supplemented crickets (Acheta domesticus). All values, except for dry matter, are reported on a dry matter basis.

\begin{tabular}{|c|c|c|c|c|c|c|}
\hline \multirow[b]{2}{*}{ Nutrient } & \multicolumn{4}{|c|}{ Requirement } & \multicolumn{2}{|c|}{$\begin{array}{c}\text { Non-Supplemented } \\
\text { A. domesticus Concentration }\end{array}$} \\
\hline & $\begin{array}{l}\text { Carnivorous } \\
\text { Reptile }^{1}\end{array}$ & $\begin{array}{l}\text { Omnivorous } \\
\text { Reptile }^{1}\end{array}$ & $\begin{array}{c}\text { Coturnix } \\
\text { japonica } \\
\text { (Starting \& } \\
\text { Growing) }\end{array}$ & $\begin{array}{c}\text { Coturnix } \\
\text { japonica } \\
\text { (Breeding) }^{2}\end{array}$ & Reference $\mathrm{A}^{3}$ & Reference $\mathrm{B}^{4}$ \\
\hline Dry matter, \% & - & - & - & - & 29.9 & $26.8 \pm 1.9$ \\
\hline Ash, $\%$ & - & - & - & - & 6.1 & $5.1 \pm 1.4$ \\
\hline Calcium, \% & $0.8-1.1$ & $1.0-1.5$ & 0.8 & 2.5 & 0.18 & $0.21 \pm 0.03$ \\
\hline Phosphorus, \% & $0.5-0.9$ & $0.6-0.9$ & $0.30^{6}$ & $0.35^{6}$ & 0.86 & $0.78 \pm 0.08$ \\
\hline $\mathrm{Ca}: \mathrm{P}, \%^{7}$ & $1.2-1.6$ & $1.6-1.7$ & - & - & 0.21 & 0.26 \\
\hline Potassium, \% & $0.4-0.6$ & $0.4-0.6$ & 0.4 & 0.4 & 1.27 & - \\
\hline Magnesium, \% & 0.04 & 0.2 & 0.03 & 0.05 & 0.105 & $0.08 \pm 0.01$ \\
\hline Sodium, \% & 0.2 & 0.2 & 0.15 & 0.15 & 0.50 & - \\
\hline Chlorine, \% & - & - & 0.14 & 0.14 & - & - \\
\hline Iron, $\mathrm{mg} / \mathrm{kg}$ & $60-80$ & 200 & 120 & 60 & 230 & $112.33 \pm 58.10$ \\
\hline Zinc, mg/kg & 5 & 150 & 25 & 50 & 217 & $186.36 \pm 16.48$ \\
\hline Manganese, $\mathrm{mg} / \mathrm{kg}$ & $5-8$ & 15 & 60 & 60 & 50.0 & $29.65 \pm 4.54$ \\
\hline Copper, mg/kg & 50 & 130 & 5 & 5 & 21 & $8.50 \pm 1.01$ \\
\hline Iodine, $\mathrm{mg} / \mathrm{kg}$ & 0.3 & 0.3 & 0.3 & 0.3 & - & - \\
\hline Selenium (added), $\mathrm{mg} / \mathrm{kg}$ & $0.3-0.6$ & 0.4 & 0.2 & 0.2 & 0.49 & - \\
\hline Sulfur, \% & - & - & - & - & - & - \\
\hline
\end{tabular}

${ }^{2} \mathrm{NRC}, 1994$.

${ }^{3}$ Allen, 1989. Listed values represent commercial A. domesticus, age unspecified.

${ }^{4}$ Barker et al., 1998. References provided include \pm standard error. Listed values represent commercial adult $A$. domesticus. 
${ }^{6}$ Provided as non-phytate phosphorus.

${ }^{7}$ Calculated as calcium $\% \div$ phosphorus $\%$. 
Table 4. Wavelength used to quantify corresponding mineral during inductively coupled plasma spectroscopy (Ultima 2; ICP Analyst 5.4; Horiba Scientific, Edison, NJ).

\begin{tabular}{lr}
\hline Mineral & Wavelength $(\mathrm{nm})$ \\
\hline Calcium & 315.687 \\
Phosphorus & 213.616 \\
Potassium & 766.490 \\
Magnesium & 279.806 \\
Sodium & 588.995 \\
Iron & 259.940 \\
Zinc & 213.856 \\
Manganese & 259.373 \\
Copper & 224.700 \\
Sulfur & 161.976
\end{tabular}


Table 5. Mean mass $(\mathrm{g}) \pm$ standard error (SE) of whole crickets and crop.

\begin{tabular}{lllllll}
\hline Measurement, $(\mathrm{g})$ & $n$ & Male & $n$ & Female & $n$ & Average \\
\hline Whole Cricket & 219 & $0.3635 \pm 0.0041$ & 341 & $0.5625 \pm 0.0046$ & 560 & $0.4846 \pm 0.0052$ \\
Crop & 218 & $0.0095 \pm 0.0004$ & 341 & $0.0161 \pm 0.0005$ & 559 & $0.0136 \pm 0.0004$ \\
\hline
\end{tabular}

Table 6. General linear model results using crop weight as the response variable. Degrees of freedom (df), F-value (F) and probability (P-value) are reported. Factors considered significant when $P \leq 0.05$.

\begin{tabular}{lccl}
\hline Factor & df & F-value & $P$-value \\
\hline $\begin{array}{l}\text { Whole Cricket } \\
\text { Weight (g) }\end{array}$ & 1 & 28.6780 & $<0.0001^{*}$ \\
$\begin{array}{l}\text { Crop Contents } \\
\text { (Y/N) (Nominal) }\end{array}$ & 1 & 136.7744 & $<0.0001^{*}$ \\
Sex (Nominal) & 1 & 1.8079 & 0.1793 \\
Date & 2 & 2.6038 & 0.0749 \\
Time (h) [Date] & 4 & 1.2295 & 0.2972 \\
Bin (Nominal) & 7 & 1.7163 & 0.1026 \\
\hline
\end{tabular}


Table 7. Mean mass $(\mathrm{g}) \pm$ standard error (SE) of whole crickets and components of the gastrointestinal tract.

\begin{tabular}{|c|c|c|c|c|c|c|}
\hline Measurement, (g) & $n$ & Male & $n$ & Female & $n$ & Average \\
\hline Whole Cricket & 2 & $0.3068 \pm 0.0096$ & 6 & $0.3930 \pm 0.0151$ & 8 & $0.3714 \pm 0.0510$ \\
\hline Total GIT & 4 & $0.0400 \pm 0.0057$ & 10 & $0.0362 \pm 0.0029$ & 14 & $0.0374 \pm 0.0097$ \\
\hline Esophagus & 4 & $0.0006 \pm 0.0002$ & 8 & $0.0008 \pm 0.0001$ & 12 & $0.0007 \pm 0.0003$ \\
\hline Crop & 5 & $0.0045 \pm 0.0012$ & 10 & $0.0050 \pm 0.0011$ & 15 & $0.0049 \pm 0.0031$ \\
\hline Proventriculus & 5 & $0.0045 \pm 0.0007$ & 10 & $0.0056 \pm 0.0005$ & 15 & $0.0053 \pm 0.0015$ \\
\hline Ceca & 3 & $0.0051 \pm 0.0012$ & 9 & $0.0074 \pm 0.0014$ & 12 & $0.0068 \pm 0.0039$ \\
\hline $\begin{array}{l}\text { Ventriculus } \\
\text { (Midgut) }\end{array}$ & 4 & $0.0017 \pm 0.0008$ & 6 & $0.0020 \pm 0.0006$ & 10 & $0.0019 \pm 0.0014$ \\
\hline Ileum & 1 & $0.0225 \pm 0.0000$ & 4 & $0.0051 \pm 0.0009$ & 5 & $0.0086 \pm 0.0079$ \\
\hline $\begin{array}{l}\text { Ileum + Rectum + } \\
\text { Colon (Hindgut) }\end{array}$ & 4 & $0.0188 \pm 0.0041$ & 7 & $0.0089 \pm 0.0014$ & 11 & $0.0124 \pm 0.0073$ \\
\hline
\end{tabular}


Table 8. Macronutrient, amino acid, fatty acid, and structural carbohydrate composition of maintenance and supplemented gut-loading cricket diets. All values, except dry matter, are expressed on a dry matter basis.

\begin{tabular}{|c|c|c|c|c|}
\hline & \multicolumn{2}{|c|}{ Maintenance Diet } & \multicolumn{2}{|c|}{ Supplemented Diet } \\
\hline Nutrient & As Reported ${ }^{1}$ & As Analyzed & As Reported ${ }^{2}$ & As Analyzed \\
\hline Dry Matter, $\%^{3}$ & 88.0 & 90.11 & 88.0 & 93.61 \\
\hline Ash, $\%{ }^{4}$ & 7.27 & 7.76 & 21.59 & 27.67 \\
\hline Gross Energy, kcal/kg & - & 4608.46 & - & 4293.24 \\
\hline Crude Protein, \% & 22.73 & - & 34.09 & - \\
\hline Arginine, $\%$ & - & - & 2.05 & - \\
\hline Cystine, \% & - & - & 0.51 & - \\
\hline Glycine, \% & - & - & 1.82 & - \\
\hline Histidine, $\%$ & - & - & 0.76 & - \\
\hline Isoleucine, $\%$ & - & - & 1.48 & - \\
\hline Leucine, $\%$ & - & - & 3.07 & - \\
\hline Lysine, \% & - & - & 1.93 & - \\
\hline Methionine, $\%$ & - & - & 0.75 & - \\
\hline Phenylalanine, \% & - & - & 1.48 & - \\
\hline Tyrosine, $\%$ & - & - & 1.25 & - \\
\hline Threonine, $\%$ & - & - & 1.36 & - \\
\hline Tryptophan, \% & - & - & 0.36 & - \\
\hline Valine, $\%$ & - & - & 1.70 & - \\
\hline Fat (Ether extract), \% & 6.82 & - & 17.05 & - \\
\hline Linoleic acid, \% & - & - & 0.98 & - \\
\hline Omega-3 fatty acids, $\%$ & - & - & 6.02 & - \\
\hline Omega- 6 fatty acids, $\%$ & - & - & 1.59 & - \\
\hline Crude Fiber, \% & 11.36 & - & 10.23 & - \\
\hline Neutral Detergent Fiber, \% & - & - & 5.80 & - \\
\hline Acid Detergent Fiber, $\%$ & - & - & 1.93 & - \\
\hline
\end{tabular}

${ }^{1}$ Maintenance diet values reported are based on guaranteed analysis and dry matter values of Mazuri ${ }^{\circledR}$ Cricket Diet

\#5M7Q, Purina Mills, LLC unless otherwise indicated (Mazuri, 2017).

${ }^{2}$ Supplemented diet values reported are based on guaranteed analysis and dry matter values of Mazuri ${ }^{\circledR}$ Better Bug®

Gut Loading Diet \#5B45, Purina Mills, LLC unless otherwise indicated (Mazuri, 2016).

${ }^{3}$ Value generated using a forced-air drying oven in the Comparative Nutrition Laboratory, California Polytechnic

State University, San Luis Obispo (NFTA, 1993, Method 2.2.2.2). This value was used to determine nutrient composition on a dry matter basis when nutrients were measured on site. 
${ }^{4}$ Value generated by igniting a dried, ground sample in a muffle furnace at $600^{\circ} \mathrm{C}$ for $6 \mathrm{~h}$ in the Comparative

Nutrition Laboratory, California Polytechnic State University, San Luis Obispo (adapted from NFTA, 1993, Method 7). 
Table 9. Mineral and ash composition of maintenance and supplemented gut-loading cricket diets.

\begin{tabular}{|c|c|c|c|c|}
\hline \multirow[b]{2}{*}{ Nutrient } & \multicolumn{2}{|c|}{ Maintenance Diet } & \multicolumn{2}{|c|}{ Supplemented Diet } \\
\hline & As Reported ${ }^{1}$ & As Analyzed & As Reported ${ }^{2}$ & As Analyzed \\
\hline Ash, $\%^{3}$ & 7.27 & 7.76 & 21.59 & 27.67 \\
\hline Calcium, \% & 1.25 & 1.58 & 10.23 & 11.32 \\
\hline Phosphorus, \% & 1.0 & 1.08 & 1.02 & 1.01 \\
\hline Phosphorus (non-phytate), \% & - & - & 0.80 & - \\
\hline $\mathrm{Ca}: \mathrm{P}, \%$ & 1.25 & 1.46 & 10.02 & 11.21 \\
\hline Potassium, $\%$ & - & 1.20 & 0.76 & 0.77 \\
\hline Magnesium, \% & - & 0.33 & - & 0.245 \\
\hline Sodium, \% & 0.25 & 0.21 & 0.42 & 0.37 \\
\hline Chlorine, \% & - & - & 0.48 & - \\
\hline Iron, $\mathrm{mg} / \mathrm{kg}$ & 312.5 & 344.84 & 659.09 & 465.78 \\
\hline Zinc, $\mathrm{mg} / \mathrm{kg}$ & 136.36 & 164.39 & 130.68 & 130.51 \\
\hline Manganese, $\mathrm{mg} / \mathrm{kg}$ & - & 173.23 & 142.05 & 83.16 \\
\hline Copper, mg/kg & 19.32 & 16.96 & 13.64 & 8.87 \\
\hline Iodine, $\mathrm{mg} / \mathrm{kg}$ & - & - & 1.14 & - \\
\hline Selenium (added), $\mathrm{mg} / \mathrm{kg}$ & 0.01 & - & 0.10 & - \\
\hline Sulfur, $\%$ & - & 0.34 & - & 0.48 \\
\hline
\end{tabular}

${ }^{1}$ Maintenance diet values reported are based on guaranteed analysis and dry matter values of Mazuri ${ }^{\circledR}$ Cricket Diet

\#5M7Q, Purina Mills, LLC unless otherwise indicated (Mazuri, 2017).

${ }^{2}$ Supplemented diet values reported are based on guaranteed analysis and dry matter values of Mazuri ${ }^{\circledR}$ Better Bug®

Gut Loading Diet \#5B45, Purina Mills, LLC unless otherwise indicated (Mazuri, 2016).

${ }^{3}$ Value generated by igniting a dried, ground sample in a muffle furnace at $600^{\circ} \mathrm{C}$ for $6 \mathrm{~h}$ in the Comparative Nutrition Laboratory, California Polytechnic State University, San Luis Obispo (adapted from NFTA, 1993, Method 7). 
Table 10. Vitamin composition of maintenance and supplemented gut-loading cricket diets. All values are expressed on a dry matter basis.

\begin{tabular}{lrrrr} 
& \multicolumn{2}{c}{ Maintenance Diet $^{2}$ Supplemented Diet } \\
\hline Nutrient & As Reported $^{1}$ & As Analyzed & As Reported & As Analyzed \\
\hline Thiamin, ppm & - & - & 26.14 & - \\
Riboflavin, ppm & - & - & 42.05 & - \\
Niacin, ppm & - & - & 215.91 & - \\
Pantothenic acid, ppm & - & - & 71.59 & - \\
Choline, ppm & - & - & 1437.50 & - \\
Folic Acid, ppm & - & - & 6.36 & - \\
Pyridoxine, ppm & - & - & 23.86 & - \\
Biotin, ppm & - & - & 0.76 & - \\
Vitamin B12, ug/kg & - & - & 85.23 & - \\
Vitamin A, IU/kg & 9181.82 & - & 17954.55 & - \\
Vitamin D3, IU/kg & 1954.55 & - & 2761.36 & - \\
Vitamin E, IU/kg & 45.45 & - & 250.00 & - \\
Vitamin K, IU/kg & - & - & 0.66 & - \\
Beta-carotene, ppm & 10.80 & - & 136.36 & -
\end{tabular}

${ }^{1}$ Maintenance diet values reported are based on guaranteed analysis and dry matter values of Mazuri® Cricket Diet \#5M7Q, Purina Mills, LLC unless otherwise indicated (Mazuri, 2017).

${ }^{2}$ Supplemented diet values reported are based on guaranteed analysis and dry matter values of Mazuri® Better Bug®

Gut Loading Diet \#5B45, Purina Mills, LLC unless otherwise indicated (Mazuri, 2016). 
Table 11. Mean nutrient composition $( \pm \mathrm{SE})$ at each time point for maintenance and supplemented gutloading cricket diets. Significant differences $(\mathrm{P} \leq 0.005)$ between diets are denoted $(*)$. All values, except dry matter, reported on a dry matter basis. Calcium values within the supplemented diet are significantly different when a superscript letter is not shared.

\begin{tabular}{|c|c|c|c|c|c|}
\hline Nutrient & Time (h) & Maintenance Diet $^{1,3}$ & Supplemented Diet ${ }^{2,3}$ & F-value & $P$-value ${ }^{4}$ \\
\hline \multirow[t]{6}{*}{ Dry Matter, $\%^{5}$} & 0 & $28.949 \pm 0.374$ & $28.896 \pm 0.168$ & 0.0061 & 0.9391 \\
\hline & 24 & $28.459 \pm 0.244$ & $28.514 \pm 0.298$ & 0.0069 & 0.9352 \\
\hline & 48 & $28.036 \pm 0.447$ & $27.655 \pm 0.102$ & 0.6021 & 0.4534 \\
\hline & 72 & $27.244 \pm 0.425$ & $27.649 \pm 0.654$ & 0.5599 & 0.4693 \\
\hline & 96 & $29.282 \pm 0.628$ & $27.994 \pm 0.322$ & 2.9000 & 0.1097 \\
\hline & 120 & $29.030 \pm 0.667$ & $28.541 \pm 0.760$ & 0.0597 & 0.8088 \\
\hline \multirow[t]{6}{*}{ Ash, $\%^{6}$} & 0 & $5.6550 \pm 0.2538$ & $5.2438 \pm 0.08542$ & 1.5673 & 0.2168 \\
\hline & 24 & $5.3120 \pm 0.3592$ & $5.9753 \pm 0.1161$ & 0.1705 & 0.6815 \\
\hline & 48 & $5.7360 \pm 0.0245 *$ & $6.4810 \pm 0.1577 *$ & 28.391 & $<0.0001$ \\
\hline & 72 & $5.3700 \pm 0.2393$ & $6.0334 \pm 0.0482$ & 7.5896 & 0.0083 \\
\hline & 96 & $5.1374 \pm 0.0600$ & $5.9151 \pm 0.0730$ & 7.6366 & 0.0083 \\
\hline & 120 & $4.7617 \pm 0.0975$ & $5.8890 \pm 0.1216$ & 8.7636 & 0.0052 \\
\hline \multirow[t]{6}{*}{ Calcium, $\%$} & 0 & $0.1650 \pm 0.0032$ & $0.1664 \pm 0.0046$ & 0.0034 & 0.9542 \\
\hline & 24 & $0.1791 \pm 0.0067 *$ & $0.6153 \pm 0.0251 * b$ & 311.45 & $<0.0001$ \\
\hline & 48 & $0.1633 \pm 0.0041 *$ & $0.6320 \pm 0.0330 * \mathrm{~b}$ & 359.73 & $<0.0001$ \\
\hline & 72 & $0.1668 \pm 0.0091 *$ & $0.5752 \pm 0.0227 * \mathrm{~b}, \mathrm{c}$ & 272.97 & $<0.0001$ \\
\hline & 96 & $0.1533 \pm 0.0037 *$ & $0.4815 \pm 0.0217 * d$ & 139.27 & $<0.0001$ \\
\hline & 120 & $0.1710 \pm 0.0021 *$ & $0.4938 \pm 0.0031 * \mathrm{c}, \mathrm{d}$ & 71.691 & $<0.0001$ \\
\hline \multirow[t]{6}{*}{ Phosphorus, \% } & 0 & $0.9641 \pm 0.0059$ & $0.9869 \pm 0.0094$ & 1.5606 & 0.2233 \\
\hline & 24 & $1.0205 \pm 0.0120$ & $1.0272 \pm 0.0089$ & 0.1316 & 0.7199 \\
\hline & 48 & $1.0079 \pm 0.0087$ & $1.0168 \pm 0.0147$ & 0.2385 & 0.6296 \\
\hline & 72 & $1.0424 \pm 0.0148 *$ & $0.9673 \pm 0.0180 *$ & 16.902 & 0.0004 \\
\hline & 96 & $1.0081 \pm 0.0062$ & $1.0481 \pm 0.0145$ & 4.0026 & 0.0547 \\
\hline & 120 & $1.0429 \pm 0.0084$ & $1.0605 \pm 0.0373$ & 0.1693 & 0.6829 \\
\hline \multirow[t]{6}{*}{$\mathrm{Ca}: \mathrm{P}, \%$} & 0 & $0.1711 \pm 0.0032$ & $0.1687 \pm 0.0053$ & 0.0118 & 0.9139 \\
\hline & 24 & $0.1754 \pm 0.0057 *$ & $0.5995 \pm 0.0261 *$ & 378.70 & $<0.0001$ \\
\hline & 48 & $0.1622 \pm 0.0053 *$ & $0.6206 \pm 0.0273 *$ & 442.45 & $<0.0001$ \\
\hline & 72 & $0.1599 \pm 0.0076 *$ & $0.5951 \pm 0.0235 *$ & 398.80 & $<0.0001$ \\
\hline & 96 & $0.1521 \pm 0.0041 *$ & $0.4592 \pm 0.0189 *$ & 153.20 & $<0.0001$ \\
\hline & 120 & $0.1639 \pm 0.0007 *$ & $0.4663 \pm 0.0193 *$ & 75.433 & $<0.0001$ \\
\hline \multirow[t]{6}{*}{ Potassium, $\%$} & 0 & $1.2200 \pm 0.0044$ & $1.2474 \pm 0.0082$ & 2.3316 & 0.1536 \\
\hline & 24 & $1.2560 \pm 0.0103$ & $1.2155 \pm 0.0166$ & 5.0960 & 0.0441 \\
\hline & 48 & $1.2562 \pm 0.0065$ & $1.2203 \pm 0.0099$ & 3.9801 & 0.0701 \\
\hline & 72 & $1.1978 \pm 0.0161$ & $1.2203 \pm 0.0122$ & 1.5715 & 0.2347 \\
\hline & 96 & $1.2548 \pm 0.0083$ & $1.2250 \pm 0.0092$ & 2.6801 & 0.1228 \\
\hline & 120 & $1.2951 \pm 0.0124$ & $1.2307 \pm 0.0088$ & 4.4151 & 0.0453 \\
\hline \multirow[t]{6}{*}{ Magnesium, \% } & 0 & $0.1466 \pm 0.0030$ & $0.1433 \pm 0.0014$ & 0.4349 & 0.5192 \\
\hline & 24 & $0.1480 \pm 0.0027$ & $0.1360 \pm 0.0027$ & 5.4429 & 0.0334 \\
\hline & 48 & $0.1327 \pm 0.0037$ & $0.1299 \pm 0.0022$ & 0.2871 & 0.5997 \\
\hline & 72 & $0.1326 \pm 0.0047$ & $0.1243 \pm 0.0039$ & 2.6109 & 0.1262 \\
\hline & 96 & $0.1425 \pm 0.0027$ & $0.1347 \pm 0.0044$ & 1.1800 & 0.2904 \\
\hline & 120 & $0.1496 \pm 0.0028$ & $0.1461 \pm 0.0001$ & 0.1348 & 0.7158 \\
\hline \multirow[t]{3}{*}{ Sodium, \% } & 0 & $0.4347 \pm 0.0052$ & $0.4412 \pm 0.0056$ & 0.4043 & 0.5392 \\
\hline & 24 & $0.4432 \pm 0.0058$ & $0.4759 \pm 0.0071$ & 10.096 & 0.0099 \\
\hline & 48 & $0.4411 \pm 0.0020 *$ & $0.4844 \pm 0.0050 *$ & 17.715 & 0.0018 \\
\hline
\end{tabular}




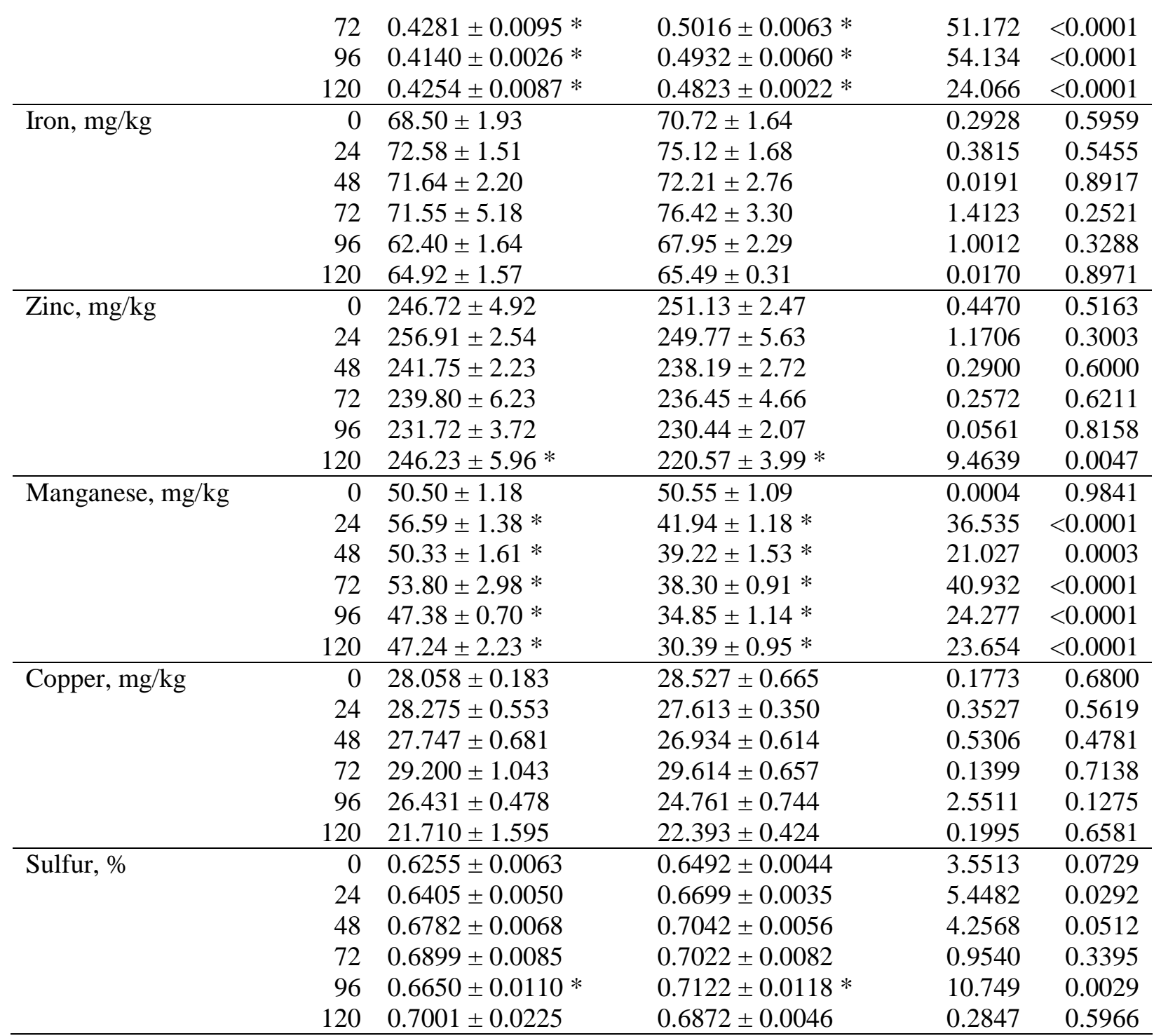

${ }^{1}$ Mazuri ${ }^{\circledR}$ Cricket Diet \#5M7Q, Purina Mills, LLC.

${ }^{2}$ Mazuri ${ }^{\circledR}$ Better Bug ${ }^{\circledR}$ Gut Loading Diet \#5B45, Purina Mills, LLC.

${ }^{3}$ Mineral values quantified using inductively coupled spectroscopy (Ultima 2; ICP Analyst 5.4; Horiba Scientific, Edison, NJ).

${ }^{4} \mathrm{~A}$ least squares means contrast test was used to determine a difference among reported diet values within a time point (JMP Pro 13, SAS, Cary, NC). An asterisk $(*)$ indicates values are considered to be significantly different $(P \leq$ $0.005)$. 
${ }^{5}$ Value generated using a forced-air drying oven in the Comparative Nutrition Laboratory, California Polytechnic State University, San Luis Obispo (NFTA, 1993, Method 2.2.2.2). This value was used to determine nutrient composition on a dry matter basis when nutrients were measured on site.

${ }^{6}$ Value generated by igniting a dried, ground sample in a muffle furnace at $600{ }^{\circ} \mathrm{C}$ for $6 \mathrm{~h}$ in the Comparative Nutrition Laboratory, California Polytechnic State University, San Luis Obispo (adapted from NFTA, 1993, Method 7).

Table 12. General linear model results using nutrients (dry matter, ash, or minerals) as the response variable. Degrees of freedom (df), F-value (F) and probability (P-value) are reported. Factors considered significant when $P \leq 0.005$, and denoted $(*)$.

\begin{tabular}{|c|c|c|c|}
\hline Factor & $\mathrm{df}$ & F-value & $P$-value \\
\hline \multicolumn{4}{|l|}{ Dry matter, \% } \\
\hline Time (h) (Ordinal) & 5 & 4.2165 & $0.0029 *$ \\
\hline Diet (Nominal) & 1 & 0.0061 & 0.9391 \\
\hline Time $(\mathrm{h}) *$ Diet & 5 & 1.2278 & 0.3106 \\
\hline $\operatorname{Bin}(\text { Diet })^{1}$ & - & - & 0.2622 \\
\hline
\end{tabular}

\begin{tabular}{|c|c|c|c|}
\hline \multicolumn{4}{|l|}{ Ash, \% } \\
\hline Time (h) (Ordinal) & 5 & 11.749 & $<0.0001 *$ \\
\hline Diet (Nominal) & 1 & 1.5673 & 0.2168 \\
\hline Time (h) * Diet & 5 & 6.0889 & $0.0002 *$ \\
\hline $\operatorname{Bin}(\text { Diet })^{1}$ & - & - & 0.6879 \\
\hline \multicolumn{4}{|l|}{ Calcium, \% } \\
\hline Time (h) (Ordinal) & 5 & 58.149 & $<0.0001 *$ \\
\hline Diet (Nominal) & 1 & 0.0034 & 0.9542 \\
\hline Time $(\mathrm{h}) *$ Diet & 5 & 55.494 & $<0.0001 *$ \\
\hline $\operatorname{Bin}(\text { Diet })^{1}$ & - & - & 0.5201 \\
\hline \multicolumn{4}{|l|}{ Phosphorus, \% } \\
\hline Time (h) (Ordinal) & 5 & 6.5456 & $<0.0001 *$ \\
\hline Diet (Nominal) & 1 & 1.5606 & 0.2233 \\
\hline
\end{tabular}




\begin{tabular}{|c|c|c|c|}
\hline Time $(\mathrm{h}) *$ Diet & 5 & 5.6537 & $0.0003 *$ \\
\hline $\operatorname{Bin}(\text { Diet })^{1}$ & - & - & 0.4429 \\
\hline \multicolumn{4}{|l|}{ Ca:P, \% } \\
\hline Time (h) (Ordinal) & 5 & 57.4068 & $<0.0001 *$ \\
\hline Diet (Nominal) & 1 & 0.0118 & 0.9139 \\
\hline Time $(\mathrm{h}) *$ Diet & 5 & 59.6837 & $<0.0001 *$ \\
\hline $\operatorname{Bin}(\text { Diet })^{1}$ & - & - & 0.7657 \\
\hline \multicolumn{4}{|l|}{ Potassium, \% } \\
\hline Time (h) (Ordinal) & 5 & 5.7331 & $0.0003 *$ \\
\hline Diet (Nominal) & 1 & 2.3316 & 0.1536 \\
\hline Time $(\mathrm{h}) *$ Diet & 5 & 5.7892 & $0.0003 *$ \\
\hline $\operatorname{Bin}(\text { Diet })^{1}$ & - & - & 0.2513 \\
\hline \multicolumn{4}{|l|}{ Magnesium, \% } \\
\hline Time (h) (Ordinal) & 5 & 10.629 & $<0.0001 *$ \\
\hline Diet (Nominal) & 1 & 0.4349 & 0.5192 \\
\hline Time $(\mathrm{h}) *$ Diet & 5 & 0.7213 & 0.6106 \\
\hline $\operatorname{Bin}(\text { Diet })^{1}$ & - & - & 0.3208 \\
\hline \multicolumn{4}{|l|}{ Sodium, \% } \\
\hline Time (h) (Ordinal) & 5 & 7.5569 & $<0.0001 *$ \\
\hline Diet (Nominal) & 1 & 0.4043 & 0.5392 \\
\hline Time $(\mathrm{h}) *$ Diet & 5 & 14.324 & $<0.0001 *$ \\
\hline $\operatorname{Bin}(\text { Diet })^{1}$ & - & - & 0.2305 \\
\hline \multicolumn{4}{|l|}{ Fe, mg/kg } \\
\hline Time (h) (Ordinal) & 5 & 3.7168 & 0.0063 \\
\hline Diet (Nominal) & 1 & 0.2928 & 0.5959 \\
\hline Time $(\mathrm{h}) *$ Diet & 5 & 0.3047 & 0.9077 \\
\hline $\operatorname{Bin}(\text { Diet })^{1}$ & - & - & 0.3182 \\
\hline
\end{tabular}

Zinc, mg/kg 


$\begin{array}{lccc}\text { Time (h) (Ordinal) } & 5 & 10.714 & <0.0001 * \\ \text { Diet (Nominal) } & 1 & 0.4470 & 0.5163 \\ \text { Time (h) }{ }^{*} \text { Diet } & 5 & 2.6078 & 0.0362 \\ \text { Bin }(\text { Diet })^{1} & - & - & 0.2395\end{array}$

\section{Manganese, $\mathrm{mg} / \mathrm{kg}$}

$\begin{array}{lccl}\text { Time }(\mathrm{h})(\text { Ordinal }) & 5 & 13.402 & <0.0001 * \\ \text { Diet }(\text { Nominal }) & 1 & 0.0004 & 0.9841 \\ \text { Time }(\mathrm{h}) * \text { Diet } & 5 & 8.8950 & <0.0001 * \\ \text { Bin }(\text { Diet })^{1} & - & - & 0.3056\end{array}$

\section{Copper, mg/kg}

$\begin{array}{lccl}\text { Time (h) (Ordinal) } & 5 & 18.001 & <0.0001 * \\ \text { Diet (Nominal) } & 1 & 0.1773 & 0.6800 \\ \text { Time (h) }{ }^{*} \text { Diet } & 5 & 1.0509 & 0.3990 \\ \text { Bin }(\text { Diet })^{1} & - & - & 0.2835\end{array}$

\begin{tabular}{|c|c|c|c|}
\hline \multicolumn{4}{|l|}{ Sulfur, \% } \\
\hline Time (h) (Ordinal) & 5 & 18.768 & $<0.0001 *$ \\
\hline Diet (Nominal) & 1 & 3.5513 & 0.0729 \\
\hline Time $(\mathrm{h}) *$ Diet & 5 & 1.6870 & 0.1554 \\
\hline $\operatorname{Bin}(\text { Diet })^{1}$ & - & - & 0.3929 \\
\hline
\end{tabular}

${ }^{1} \mathrm{Bin}$ is treated as a random effect, and probability value is determined with a Wald test. 
Table 13. Listed macromineral and trace mineral requirements of and the measured minerals achieved in adult Acheta domesticus offered either a maintenance or supplemented diet for $48 \mathrm{~h}$. All values are expressed on a dry matter basis.

\begin{tabular}{|c|c|c|c|c|c|c|}
\hline \multirow[b]{2}{*}{ Nutrient } & \multicolumn{4}{|c|}{ Requirement } & \multicolumn{2}{|c|}{$\begin{array}{l}\text { Adult Acheta domesticus, As } \\
\text { Analyzed }\end{array}$} \\
\hline & $\begin{array}{l}\text { Carnivorous } \\
\text { Reptiles }^{1}\end{array}$ & $\begin{array}{l}\text { Omnivorous } \\
\text { Reptiles }^{1}\end{array}$ & $\begin{array}{c}\text { Coturnix } \\
\text { japonica } \\
\text { (Starting \& } \\
\text { Growing) }\end{array}$ & $\begin{array}{l}\text { Coturnix } \\
\text { japonica } \\
\text { (Breeding) }^{2}\end{array}$ & $\begin{array}{l}\text { Maintenance } \\
\text { Diet }\end{array}$ & $\begin{array}{l}\text { Supplemented } \\
\text { Diet }\end{array}$ \\
\hline Calcium, $\%$ & $0.8-1.1$ & $1.0-1.5$ & 0.8 & 2.5 & 0.16 & 0.63 \\
\hline Phosphorus, \% & $0.5-0.9$ & $0.6-0.9$ & $0.30^{3}$ & $0.35^{3}$ & 1.01 & 1.02 \\
\hline $\mathrm{Ca}: \mathrm{P}, \%$ (calculated) & $1.2-1.6$ & $1.6-1.7$ & - & - & 0.16 & 0.62 \\
\hline Potassium, $\%$ & $0.4-0.6$ & $0.4-0.6$ & 0.4 & 0.4 & 1.26 & 1.22 \\
\hline Magnesium, $\%$ & 0.04 & 0.2 & 0.03 & 0.05 & 0.13 & 0.13 \\
\hline Sodium, $\%$ & 0.2 & 0.2 & 0.15 & 0.15 & 0.44 & 0.48 \\
\hline Chlorine, \% & - & - & 0.14 & 0.14 & - & - \\
\hline Iron, $\mathrm{mg} / \mathrm{kg}$ & $60-80$ & 200 & 120 & 60 & 71.6 & 72.2 \\
\hline Manganese, $\mathrm{mg} / \mathrm{kg}$ & 5 & 150 & 25 & 60 & 50.3 & 39.2 \\
\hline Copper, $\mathrm{mg} / \mathrm{kg}$ & $5-8$ & 15 & 60 & 5.0 & 27.7 & 26.9 \\
\hline Zinc, $\mathrm{mg} / \mathrm{kg}$ & 50 & 130 & 5 & 50 & 242 & 238 \\
\hline Selenium, $\mathrm{mg} / \mathrm{kg}$ & 0.3 & 0.3 & 0.3 & 0.2 & - & - \\
\hline Iodine, $\mathrm{mg} / \mathrm{kg}$ & $0.3-0.6$ & 0.4 & 0.2 & 0.3 & - & - \\
\hline Sulfur, $\%$ & - & - & - & - & 0.68 & 0.70 \\
\hline
\end{tabular}

${ }^{1}$ Nijboer, n.d.

${ }^{2} \mathrm{NRC}, 1994$.

${ }^{3}$ Provided as non-phytate phosphorus. 


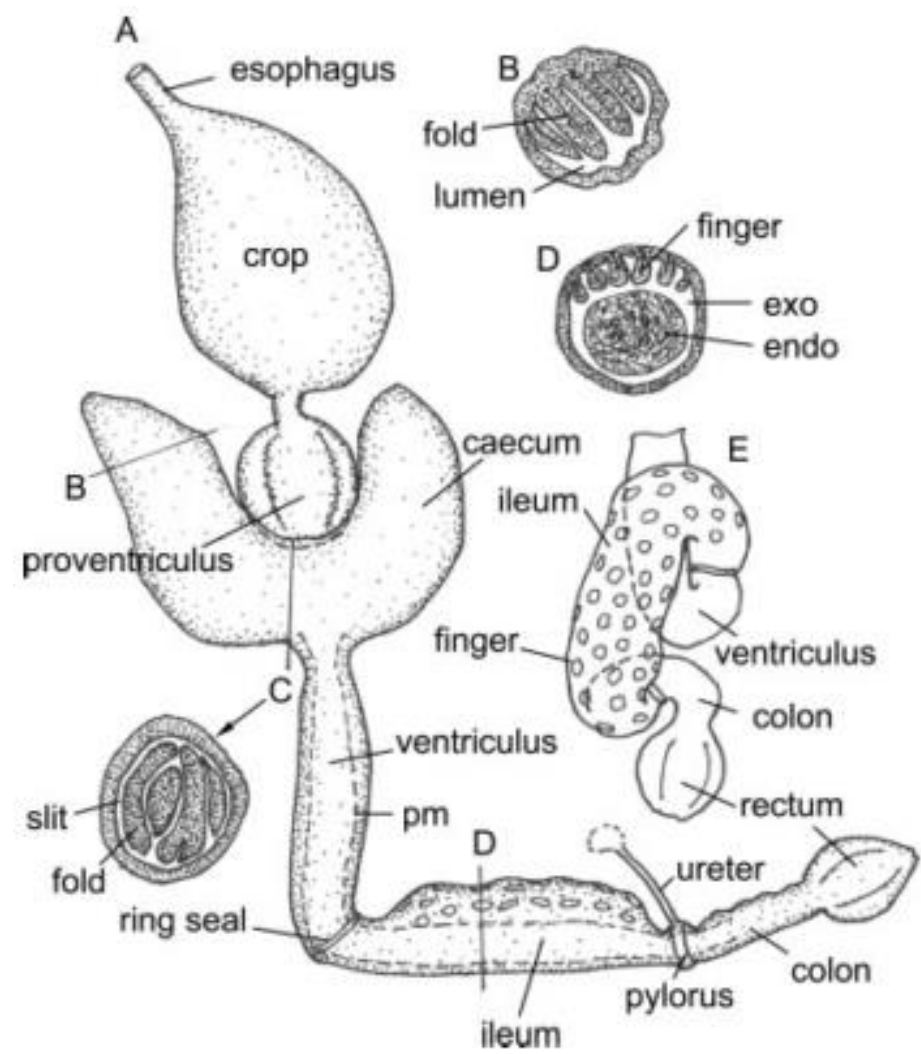

Figure 1. Gryllus bimaculatus gastrointestinal tract. (A) Entire unfolded digestive tract of an adult female. (B) Cross section of a caecum. (C) Cross section at the base of a caecum showing the filter formed from the cecal folds. (D) Cross section of ileum showing the finger-like invaginations. (E) Dorsal view of the double loop formed in the regions ventriculus to colon. All components of the tract except the ventriculus (midgut) and ileum (hindgut) are lined with an impermeable cuticle that is shed upon molting (Woodring \& Lorenz, 2007). 


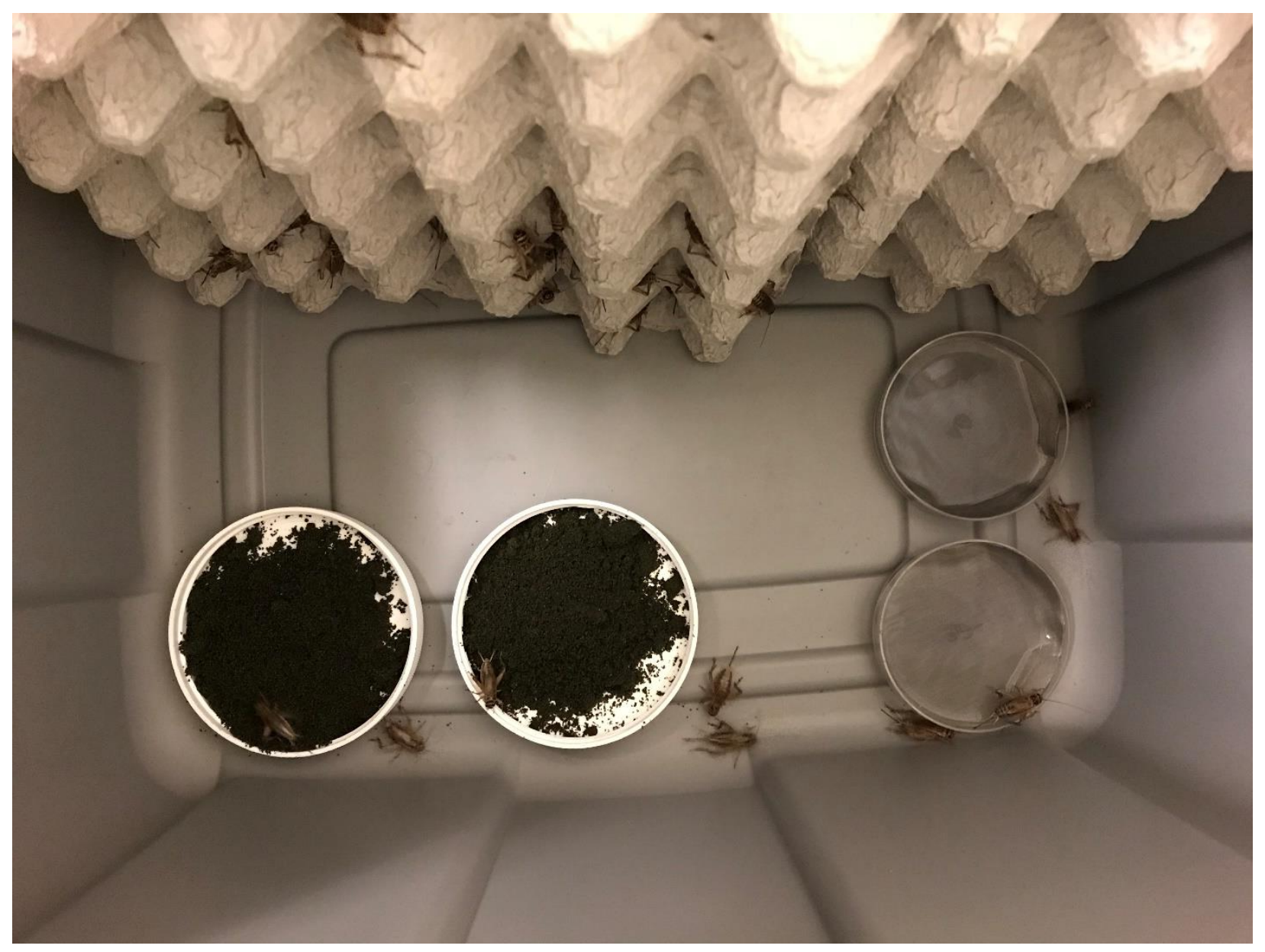

Figure 2. Enclosure used for trials. Crickets (Acheta domesticus) were kept in plastic totes. Two feed dishes on the left contained experimental diet, and the two dishes on the right contained deionized water. The diet pictured is the supplemented diet. The dishes containing water were fitted with stainless steel wire cloth to provide a substrate for crickets to walk on. Paper egg flats were included in the enclosure to provide shelter and crawl space, and have been lifted from the horizontal position in this image. 


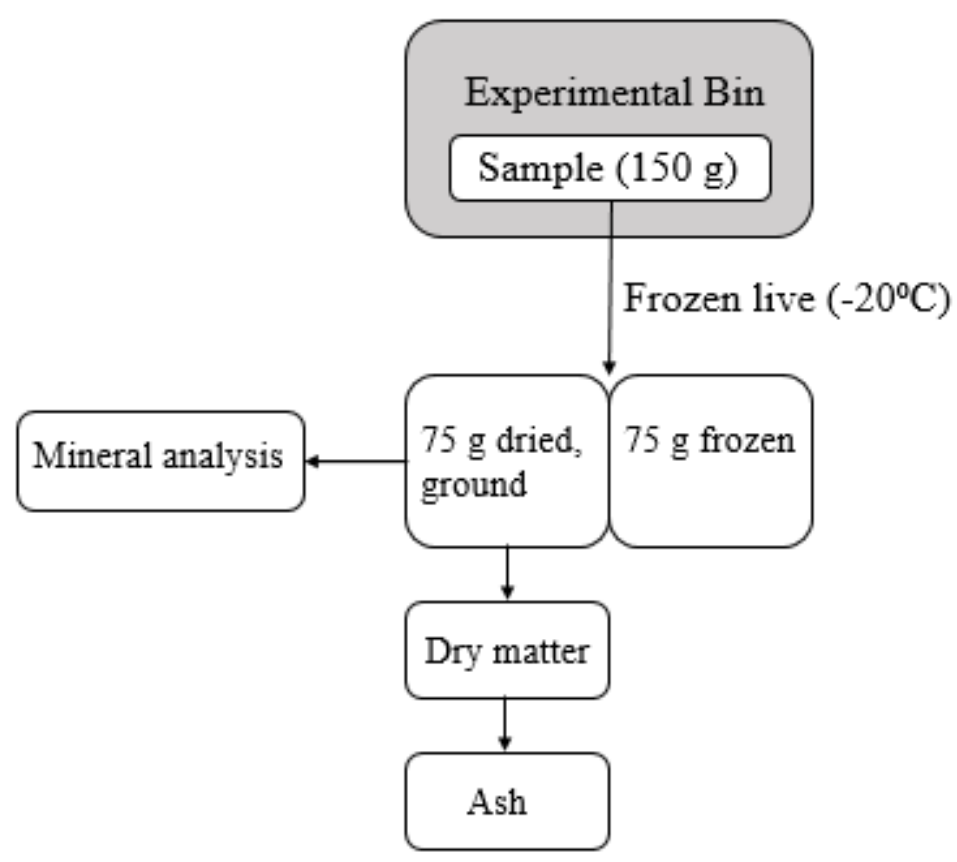

Figure 3. Cricket sample processing diagram. Dry matter and ash determination was sequential, utilizing $1.0 \mathrm{~g}$ dried, ground samples in duplicate. Mineral analysis utilized $0.5 \mathrm{~g}$ samples, in duplicate, for inductively coupled plasma spectroscopy. 


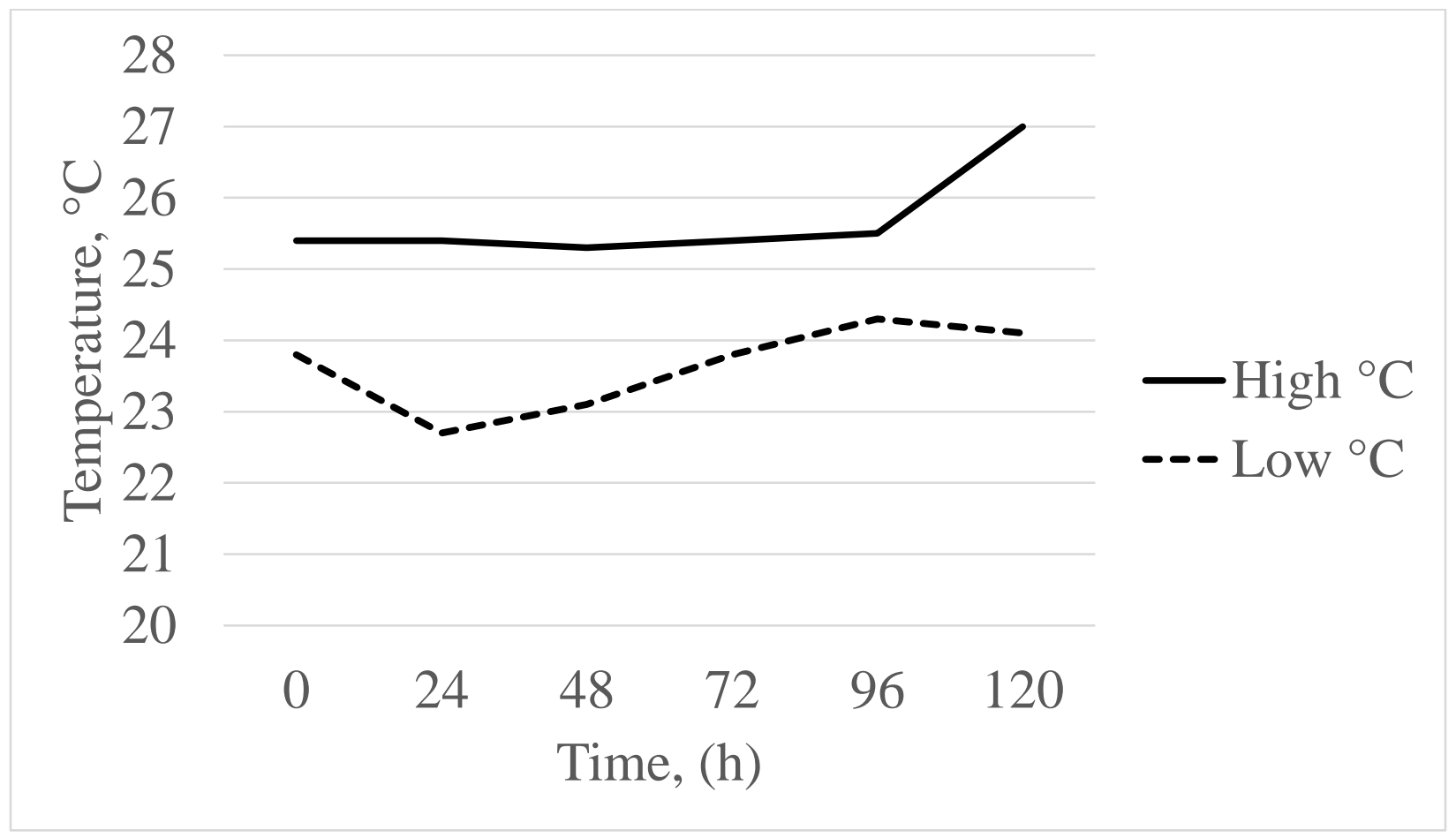

Figure 4. Summary of high and low temperature $\left({ }^{\circ} \mathrm{C}\right)$ measurements throughout the feeding trial. The temperature suggested to support regular feeding in Acheta domesticus is 28 to $35 \pm 0.5^{\circ} \mathrm{C}$ (Clifford \& Woodring, 1990; Finke \& Oonincx, 2014; Livingston et al., 2014; Roe et al., 1980; Woodring et al., 1977). 


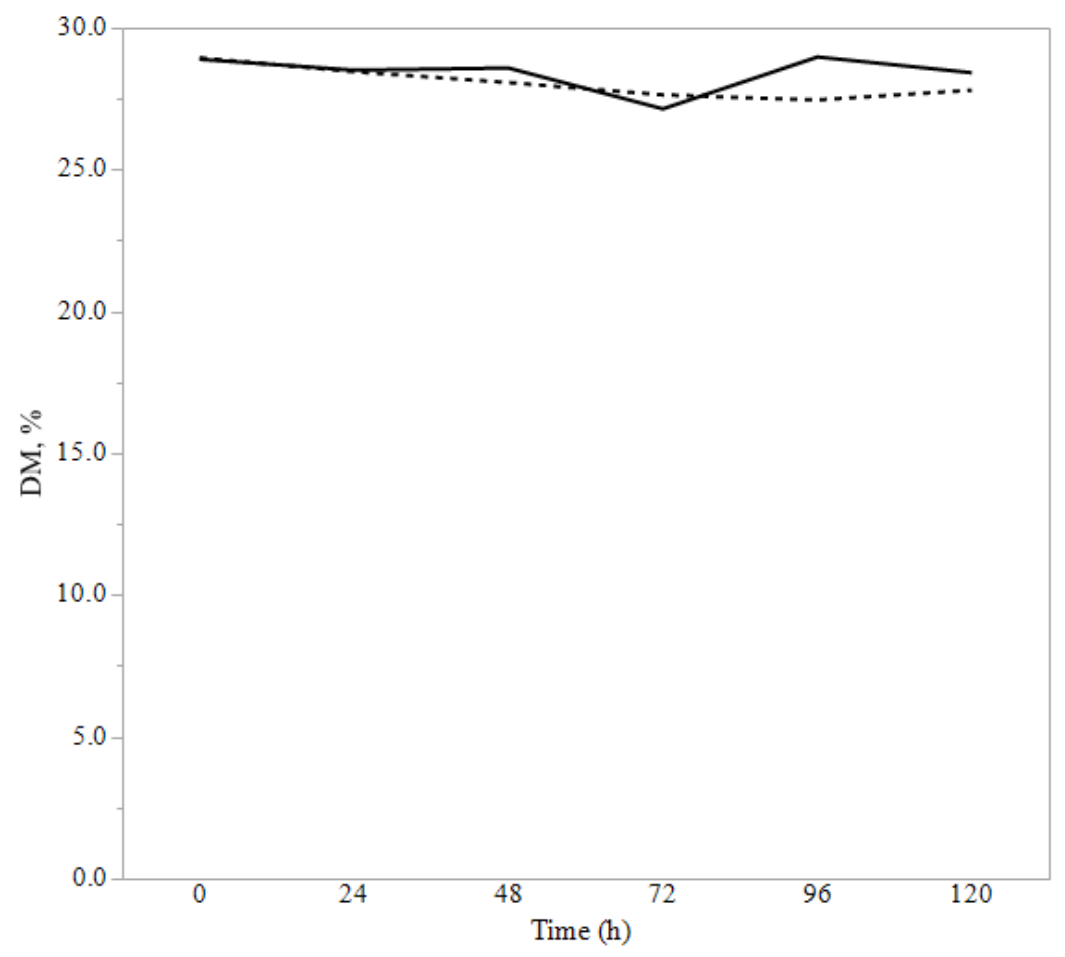

Figure 5. Line plot of mean dry matter $(\mathrm{DM}, \%)$ by time $(\mathrm{h})$. Supplemented diet $=(-)$ and maintenance diet $=(--)$. Significant differences $(P \leq 0.005)$ between mean values within a time point are denoted $(*)$. 


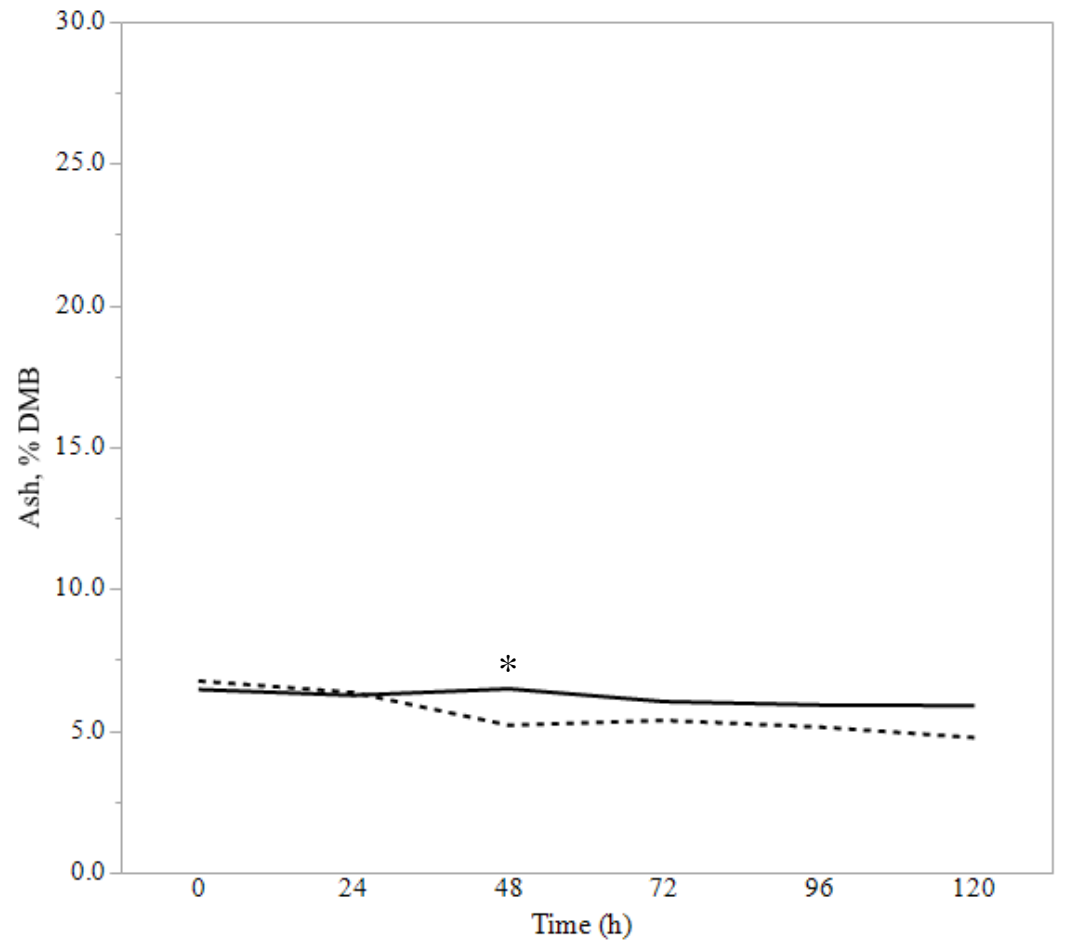

Figure 6. Line plot of mean ash $(\%, \mathrm{DMB})$ by time $(\mathrm{h})$. Supplemented diet $=(-)$ and maintenance diet $=$ $(--)$. Significant differences $(P \leq 0.005)$ between mean values within a time point are denoted $(*)$. 


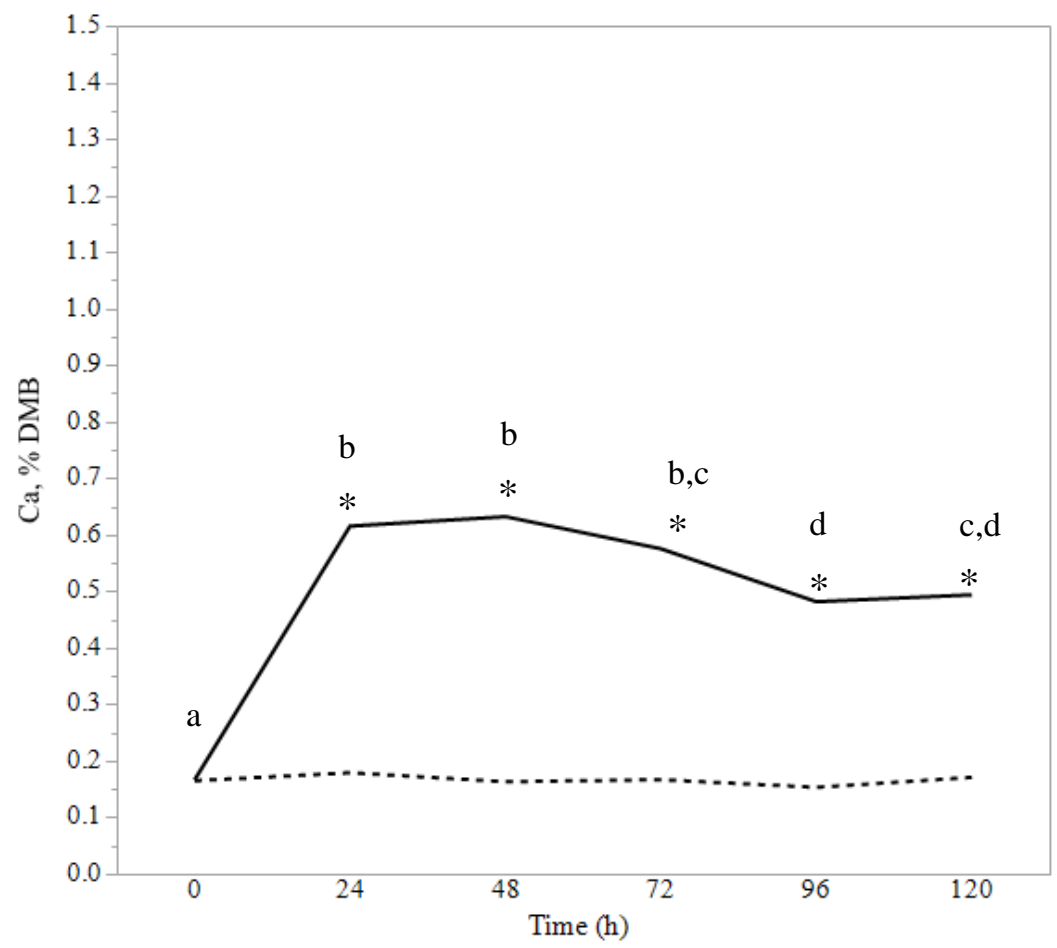

Figure 7. Line plot of mean calcium $(\mathrm{Ca}, \% \mathrm{DMB})$ by time (h). Supplemented diet $=(-)$ and maintenance diet $=(--)$. Significant differences $(P \leq 0.005)$ between mean values within a time point are denoted $(*)$. Values within the supplemented diet are significantly different when a superscript letter is not shared. 


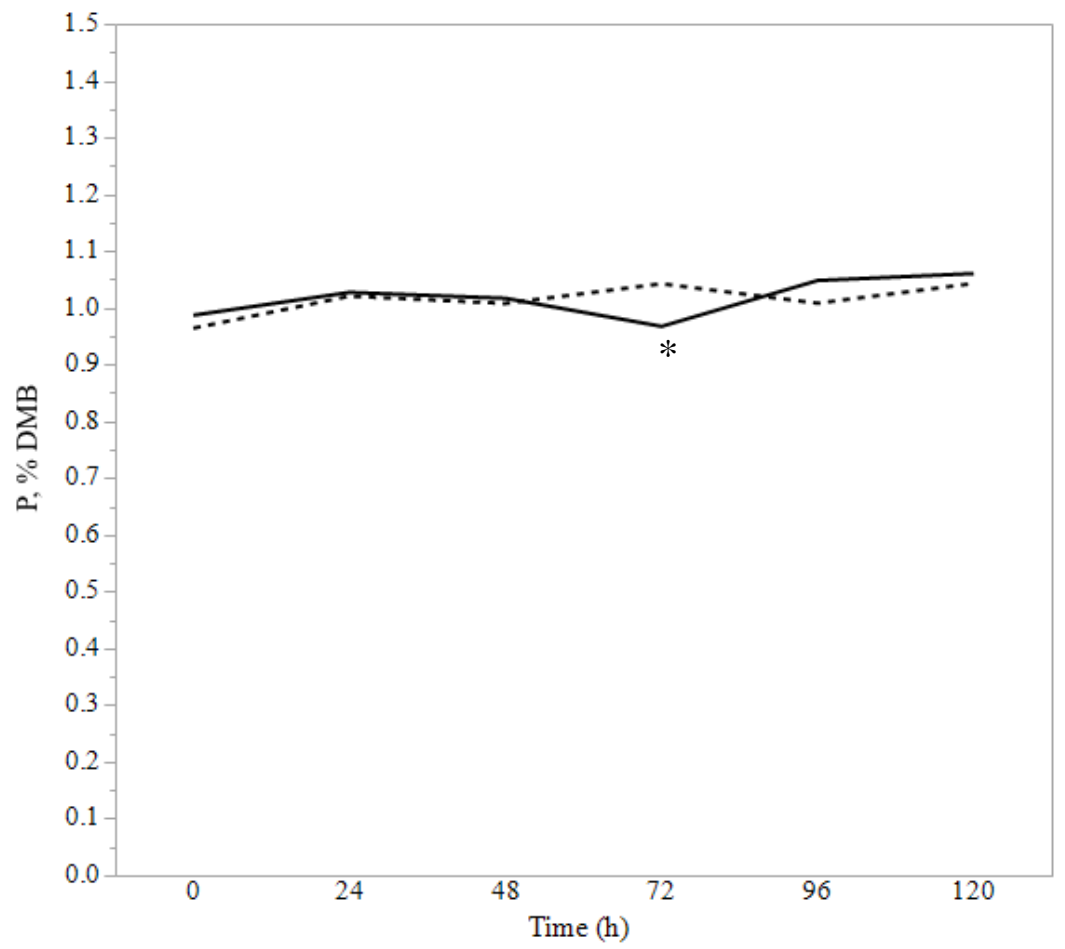

Figure 8. Line plot of mean phosphorus $(\mathrm{P}, \% \mathrm{DMB})$ by time $(\mathrm{h})$. Supplemented diet $=(-)$ and maintenance diet $=(--)$. Significant differences $(P \leq 0.005)$ between mean values within a time point are denoted $(*)$. 


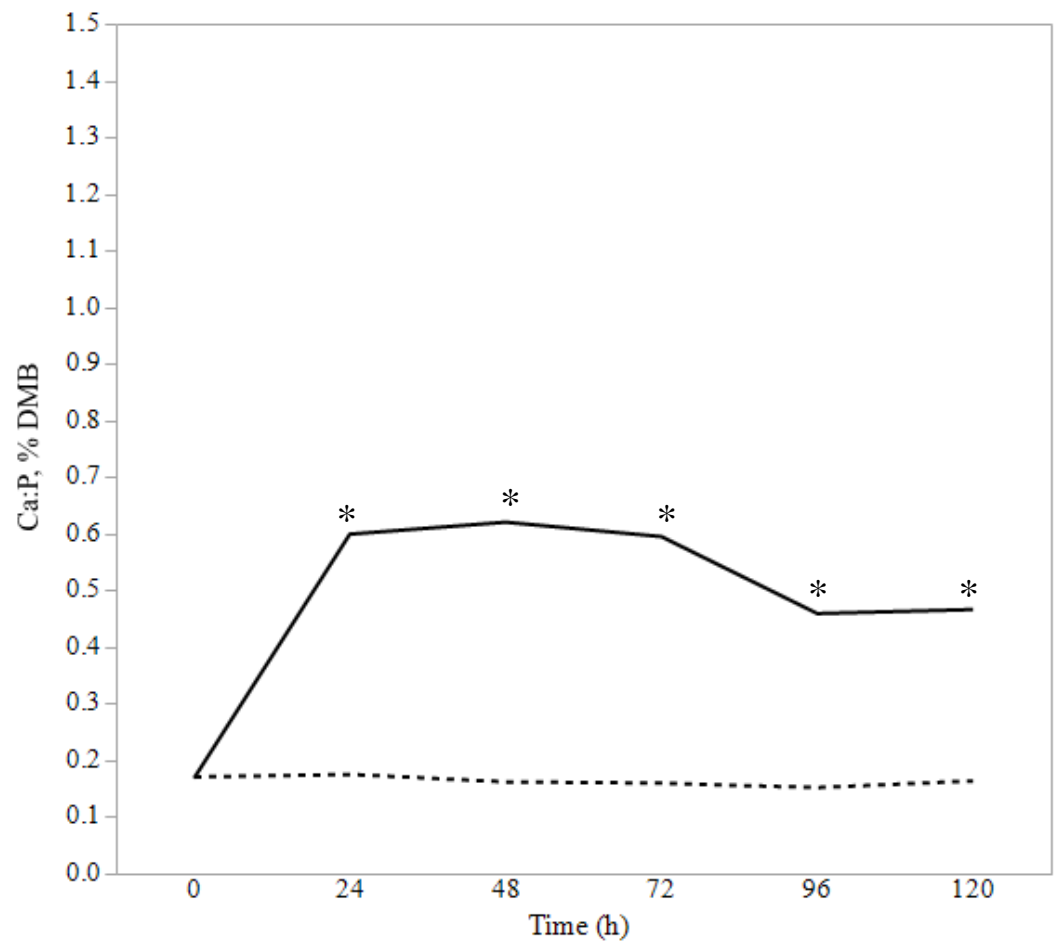

Figure 9. Line plot of mean calcium to phosphorus ratio by time (h). Supplemented diet $=(-)$ and maintenance diet $=(--)$. Significant differences $(P \leq 0.005)$ between mean values within a time point are denoted $(*)$. 


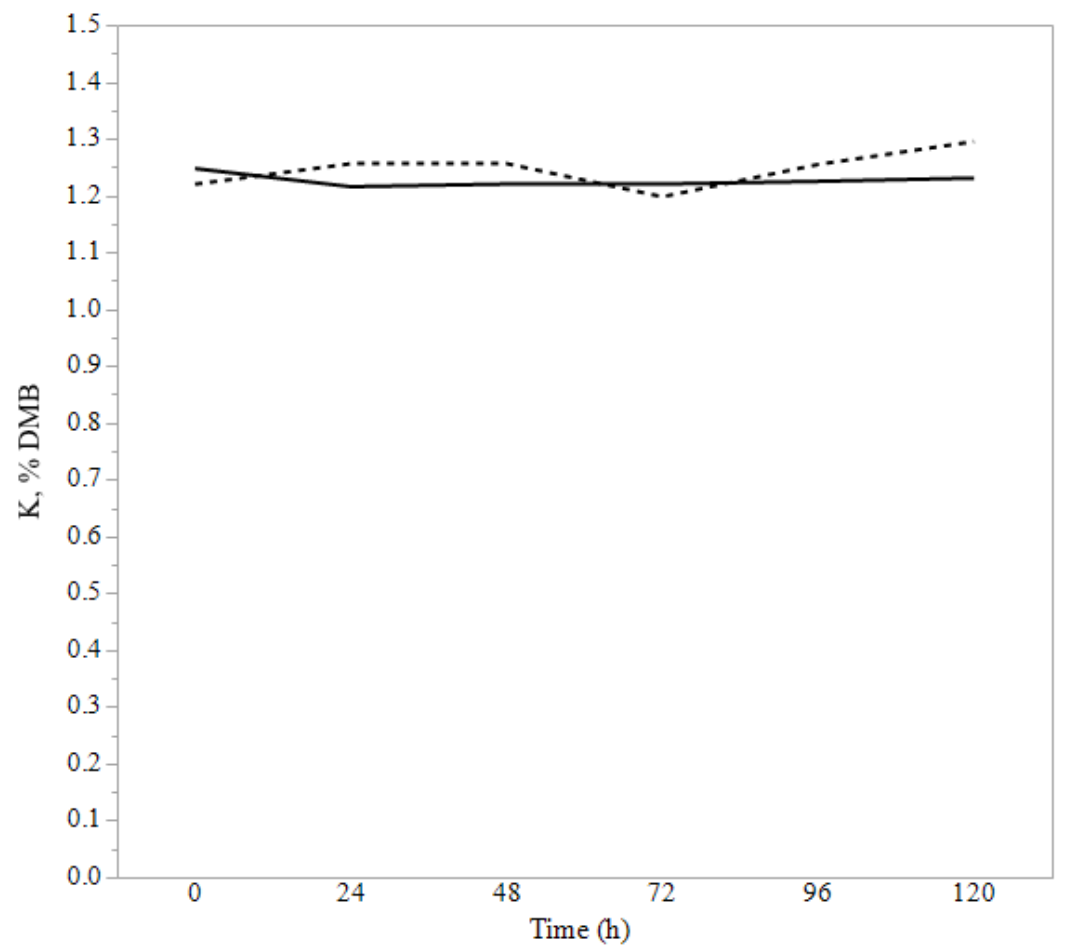

Figure 10. Line plot of mean potassium (K, \% DMB) by time (h). Supplemented diet $=(-)$ and maintenance diet $=(--)$. Significant differences $(P \leq 0.005)$ between mean values within a time point are denoted $(*)$. 


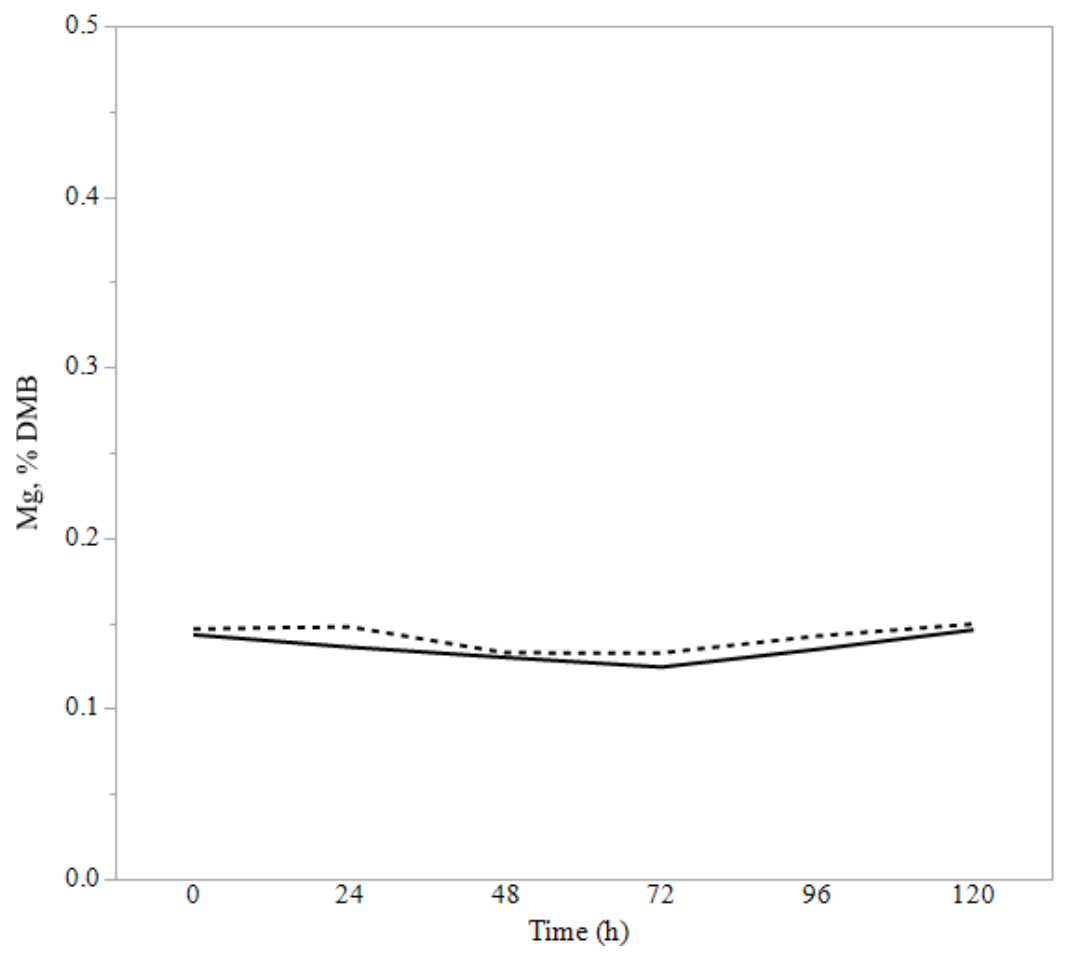

Figure 11. Line plot of mean magnesium (Mg, \% DMB) by time (h). Supplemented diet $=(-)$ and maintenance diet $=(--)$. Significant differences $(P \leq 0.005)$ between mean values within a time point are denoted $(*)$. 


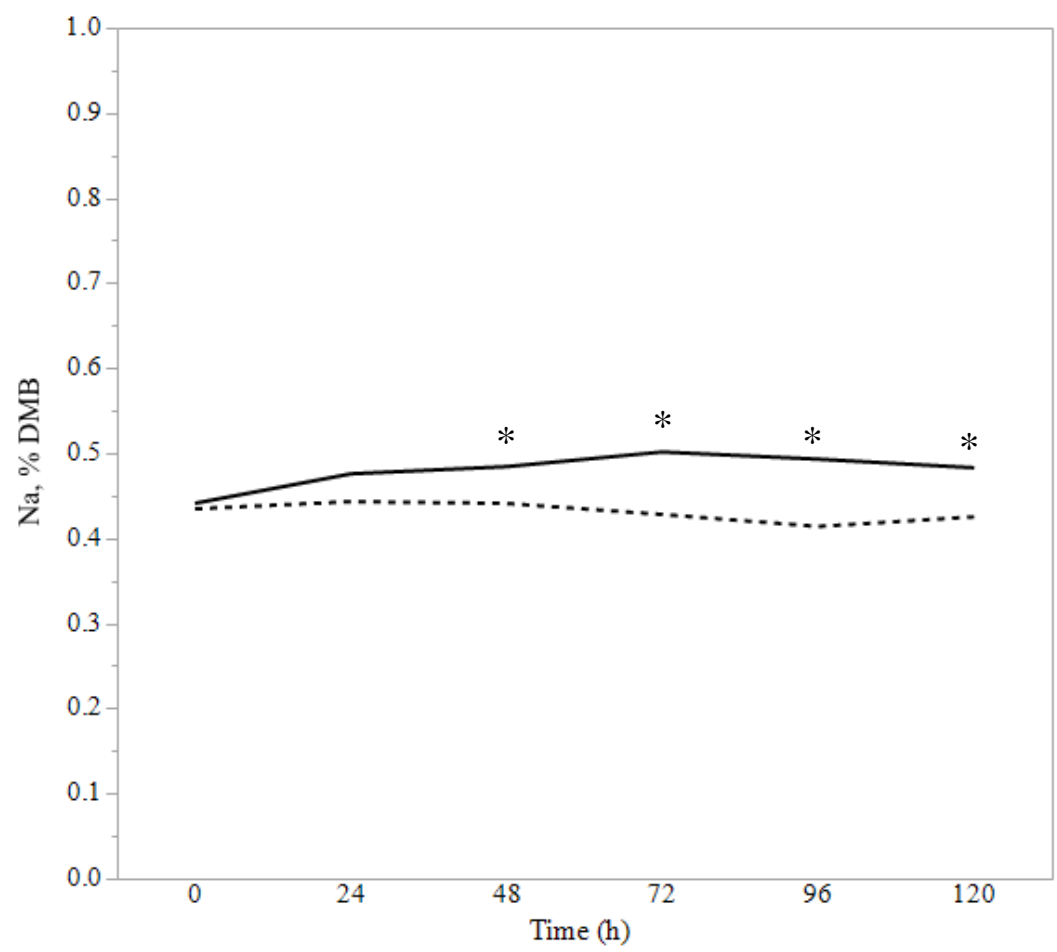

Figure 12. Line plot of mean sodium $(\mathrm{Na}, \% \mathrm{DMB})$ by time $(\mathrm{h})$. Supplemented diet $=(-)$ and maintenance diet $=(--)$. Significant differences $(P \leq 0.005)$ between mean values within a time point are denoted (*). 


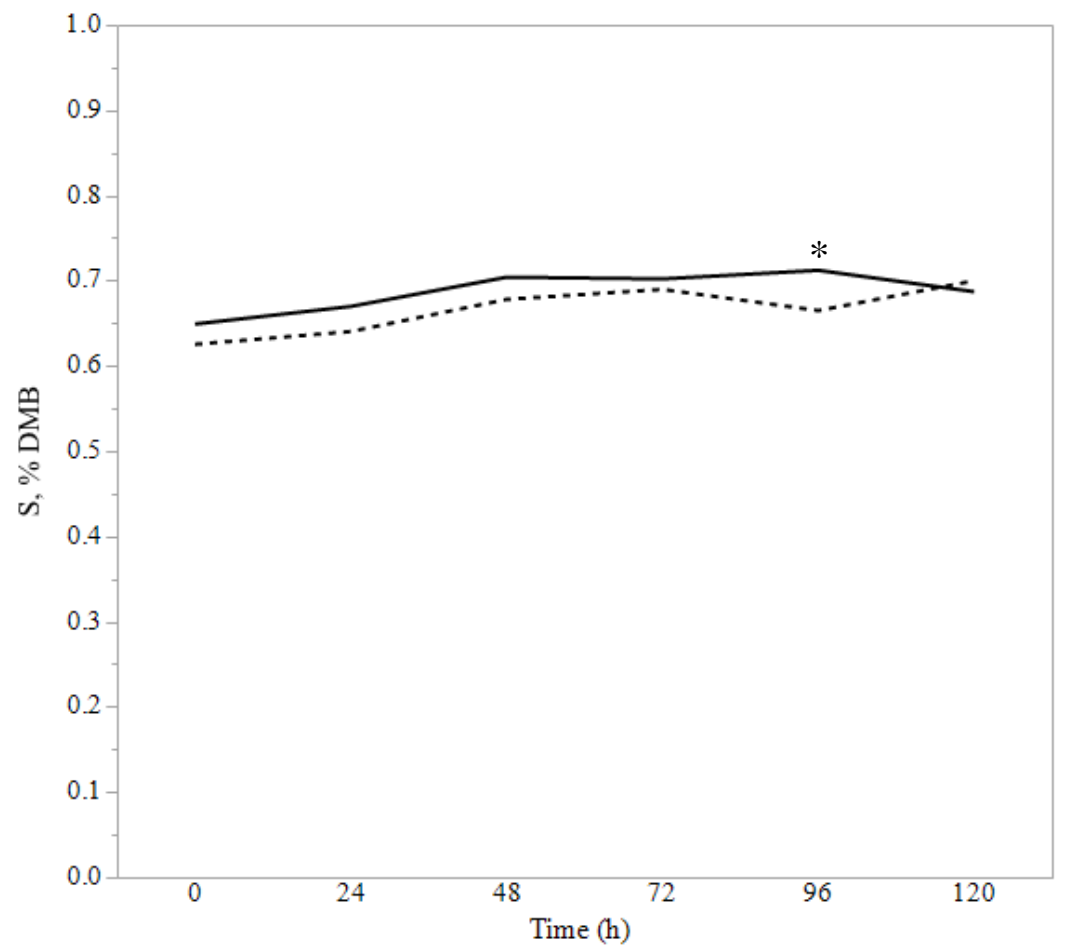

Figure 13. Line plot of mean sulfur (S, \% DMB) by time (h). Supplemented diet $=(-)$ and maintenance diet $=(--)$. Significant differences $(P \leq 0.005)$ between mean values within a time point are denoted $(*)$. 


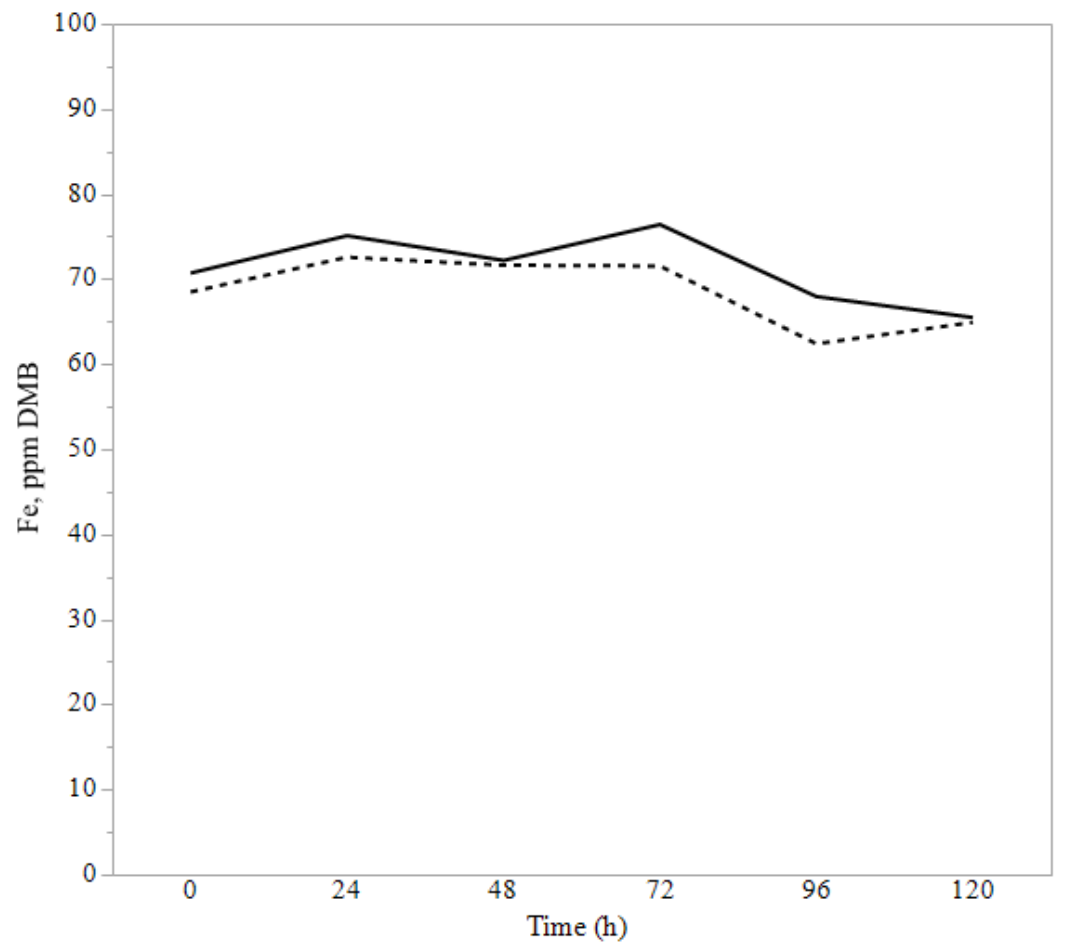

Figure 14. Line plot of mean iron (Fe, mg/kg DMB) by time (h). Supplemented diet $=(-)$ and maintenance diet $=(--)$. Significant differences $(P \leq 0.005)$ between mean values within a time point are denoted $(*)$. 


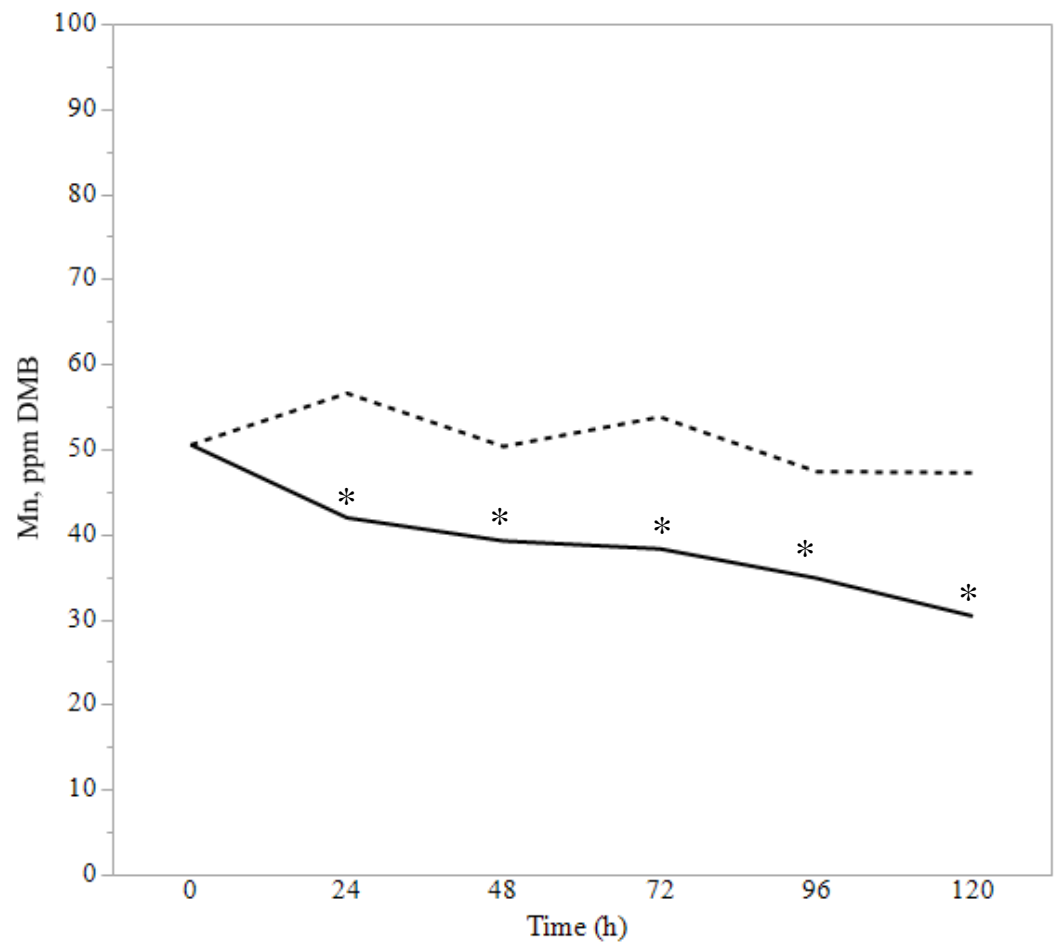

Figure 15. Line plot of mean manganese $(\mathrm{Mn}, \mathrm{mg} / \mathrm{kg} \mathrm{DMB})$ by time $(\mathrm{h})$. Supplemented diet $=(-)$ and maintenance diet $=(--)$. Significant differences between mean values within a time point are denoted $\left(^{*}\right)$. 


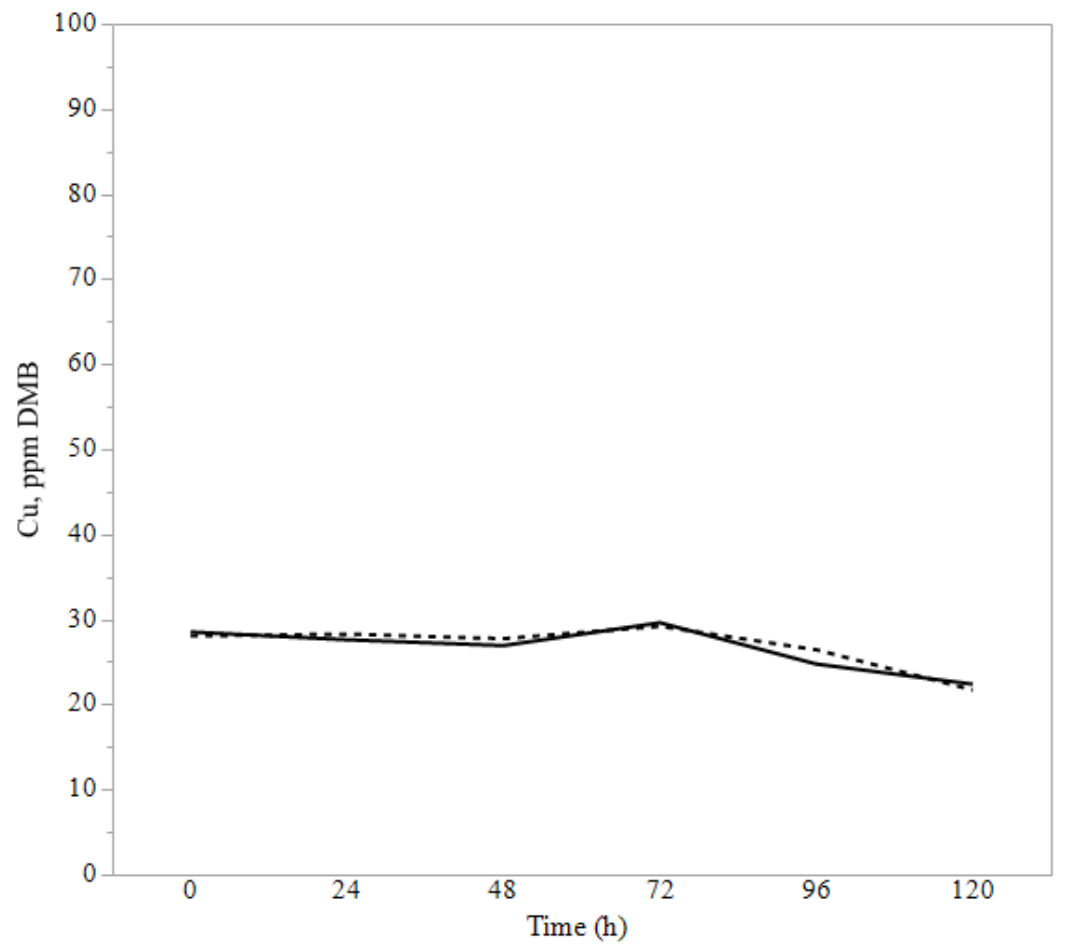

Figure 16. Line plot of mean copper, $(\mathrm{Cu}, \mathrm{mg} / \mathrm{kg} \mathrm{DMB})$ by time (h). Supplemented diet $=(-)$ and maintenance diet $=(--)$. Significant differences $(P \leq 0.005)$ between mean values within a time point are denoted $(*)$. 


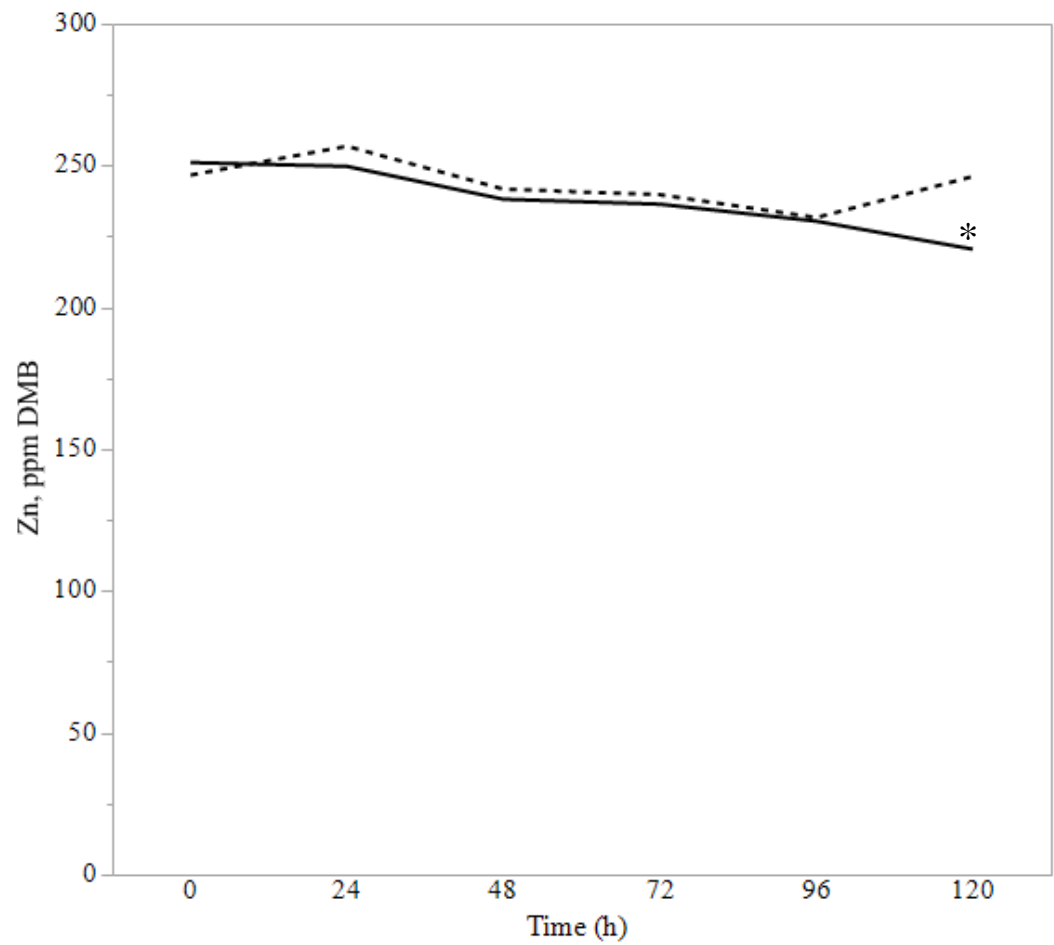

Figure 17. Line plot of mean zinc, $(\mathrm{Zn}, \mathrm{mg} / \mathrm{kg} \mathrm{DMB})$ by time $(\mathrm{h})$. Supplemented diet $=(-)$ and maintenance diet $=(--)$. Significant differences $(P \leq 0.005)$ between mean values within a time point are denoted $(*)$. 